\title{
EL DERECHO A LA VERDAD: NATURALEZA, ESTÁNDARES E INCORPORACIÓN AL CONTEXTO DE JUSTICIA TRANSICIONAL COLOMBIANO
}

\section{Tesis para optar por el título de magister}

\author{
Juan Pablo Gamboa Olaya
}

Resumen. Este trabajo de investigación da cuenta de la evolución jurídica del derecho a la verdad en el marco del Derecho Internacional de los Derechos Humanos, y de su consolidación como elemento fundamental para prevenir el fenómeno de la impunidad frente a las graves violaciones a los Derechos Humanos. Desarrolla la evolución de su juridicidad en el contexto del Sistema Interamericano de Derechos Humanos y su preponderancia frente a los contextos de justicia transicional con énfasis en el contexto colombiano.

Palabras claves: Derecho a la verdad, violaciones a los Derechos Humanos y justicia transicional.

Universidad Santo Tomas de Bogotá - Maestría en Defensa de los Derechos Humanos ante Organismos, Cortes y Tribunales Internacionales y Nacionales 


\section{CONTENIDO}

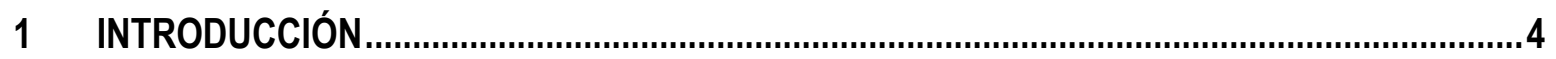

2 EVOLUCIÓN HISTÓRICA Y NATURALEZA JURÍDICA...................................................

2.1 El derecho a la verdad en el Derecho Internacional Humanitario...............................10

2.2 El derecho a la verdad en el Derecho Internacional de los Derechos Humanos.......13

2.2.1 El Grupo de Trabajo ad hoc sobre la Situación de los Derechos Humanos en Chile ...14

2.2.2 El Grupo de Trabajo sobre Desapariciones Forzadas o Involuntarias ...........................15

2.2.3 La Subcomisión de Prevención de Discriminaciones y Protección a las Minorías........16

2.2.4 Comisión de Derechos Humanos de la Organización de las Naciones Unidas ............18

2.2.5 Oficina del Alto Comisionado de las Naciones Unidas para los Derechos Humanos y Secretario General de las Naciones Unidas ........................................................................19

2.3 El Derecho a la verdad en el Sistema Interamericano de Derechos Humanos..........21

2.3.1 El Derecho a la verdad como medida de reparación. ………………...........................31

3. EL DERECHO A LA VERDAD EN CONTEXTOS DE JUSTICIA TRANSICIONAL...................37

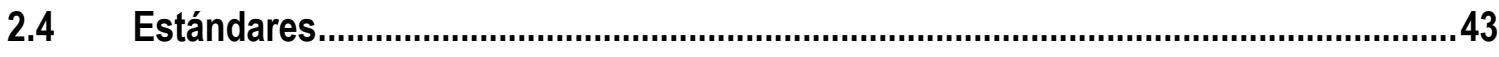

2.4.1 Derecho Internacional Humanitario ……………………..........................................4

2.4.2 Principios y directrices básicos sobre el derecho de las víctimas de violaciones manifiestas de las normas internacionales de Derechos Humanos y de violaciones graves del Derecho Internacional Humanitario a interponer recursos y obtener reparaciones ...................45

2.4.3 Conjunto de Principios para la Protección y la Promoción de los Derechos Humanos mediante la lucha contra la impunidad ...............................................................................

3 EL DERECHO A LA VERDAD EN COLOMBIA ……...................................................

3.1 El derecho a la verdad en la jurisprudencia Constitucional......................................53 
3.1.1 El derecho a la verdad como elemento esencial del derecho a un recurso judicial efectivo de las víctimas de los delitos.

3.1.2 El derecho a la verdad autónomo e inalienable ..........................................................57

3.1.3 Criterios jurisprudenciales sobre el derecho a la verdad.............................................62

4 DERECHO A LA VERDAD EN EL CONTEXTO DE JUSTICIA TRANSICIONAL COLOMBIANO 65

4.1 Ley 975 de 2005 o Ley de Justicia y Paz ….............................................................

4.2 Ley 1448 de 2011 o Ley de Víctimas y Restitución de Tierras ..................................74

4.3 Ley 1424 de 2010 - El Mecanismo no Judicial de Contribución a la Verdad y la Dirección de Acuerdos de la Verdad..................................................................................78

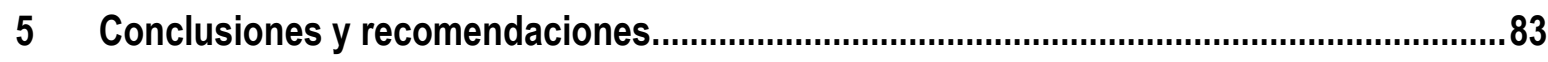

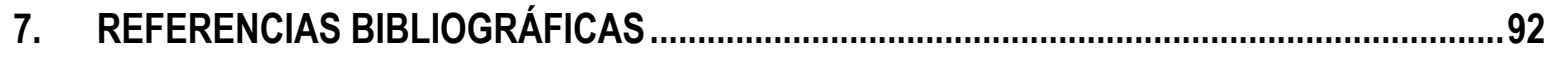




\section{INTRODUCCIÓN}

El Derecho a la verdad ha sido objeto de un desarrollo conceptual y jurídico, a partir de diferentes instrumentos de interpretación, en el marco del derecho internacional de los derechos humanos. Debido a esto se ha convertido en un elemento fundamental dentro de las obligaciones del Estado, relacionadas con la reparación integral de víctimas de graves violaciones a los derechos humanos, crímenes de lesa humanidad e infracciones al DIH. Sin embargo, la materialización de este derecho reviste una enorme complejidad, sobre todo debido al amplio margen de interpretación por parte de los Estados. Colombia ha venido implementando un marco jurídico de justicia transicional, con el cual se ha querido regular el derecho de las víctimas a la reparación integral, así como la desmovilización y reintegración de miembros de grupos armados al margen de la Ley (Ley 975 de 2005, Ley 1448 de 2011, Ley 1592 de 2012, Ley 1424 de 2010 y el Acto legislativo 01 o marco jurídico para la paz). A partir de los instrumentos jurídicos de carácter interno, se han establecido en el país diferentes mecanismos para la garantía del derecho a la verdad, sin embargo, al igual que en el derecho internacional, estos mecanismos se encuentran dispersos en instrumentos de carácter judicial y administrativo y le apuntan a determinados componentes que hacen parte del derecho a la verdad, pero que se confunden entre medidas de satisfacción, esclarecimiento histórico y memoria histórica. Esta investigación se orienta a establecer los componentes jurídicos esenciales del derecho a la verdad en el derecho internacional de los derechos humanos y a determinar el nivel de efectividad de este derecho a partir de su incorporación en el sistema jurídico interno, a través de los diferentes mecanismos establecidos que para ello se han dispuesto en el marco jurídico de justicia transicional con el que cuenta hoy Colombia.

El documento da cuenta de la evolución histórica del derecho a la verdad, la elaboración de estándares internacionales frente a su garantía, así como la incorporación al Sistema Regional de Protección de los Derechos Humanos, sus problemáticas interpretativas y su consecuente desarrollo en el sistema jurídico interno. Dada su íntima relación con el derecho de las víctimas de graves violaciones a los derechos humanos a obtener una reparación integral, se abordan algunas de las problemáticas que surgen de su incorporación a partir de instrumentos y mecanismos de justicia transicional. 
Esta investigación la he realizado desde un enfoque dogmático - teórico, a partir del análisis de fuentes secundarias y de la revisión de normas del ordenamiento jurídico interno e internacional. Parto del reconocimiento de la gran producción que existe hoy en Colombia sobre la justicia transicional, sin embargo, algunas de las investigaciones consultadas, se aproximan al derecho a la verdad, sin problematizar su abordaje, razón por la cual se hace necesario reflexionar sobre su naturaleza jurídica a partir de establecer elementos esenciales, sociales, jurídicos y políticos que han determinado su desarrollo.

En el contexto actual determinado por la producción de normas jurídicas que se comprenden dentro del concepto amplio de la justicia de transición, surgen debates que giran en torno a la efectividad y garantía de este derecho, así como frente a su fuerza normativa. El abordaje al derecho a la verdad desde una perspectiva exclusivamente jurídica se agota, dada la naturaleza fuertemente política, que se encuentra inmersa en los debates que surgen frente a los procesos de tránsito hacia una sociedad más democrática y que pretende afrontar un pasado caracterizado por un conflicto armado de carácter interno, de larga duración y con las complejidades que subyacen de los procesos de victimización que presenta el conflicto colombiano.

La investigación aporta elementos para comprender el contexto en cual se encuentra hoy Colombia, la gran complejidad que se revela al afrontar una pasado violento, las tensiones que se entretejen en la sociedad, muchas de ellas, se presentan con sencillas preguntas como ¿para qué recordar?, ¿qué recordar?, ¿por qué es importante la verdad?, ¿por qué no sencillamente olvidar?. Aunque en principio son las víctimas las más interesadas en la verdad, es claro que hoy en día este concepto, se relaciona con un impulso más amplio de búsqueda de un progreso moral colectivo, de construcción de un futuro más justo a partir de la comprensión del pasado. 


\section{EVOLUCIÓN HISTÓRICA Y NATURALEZA JURÍDICA}

El derecho a la verdad de las víctimas de graves violaciones a los Derechos Humanos y de sus familiares ha sido objeto de un amplio desarrollo desde su nacimiento en el Derecho Internacional Humanitario (DIH) hasta su posterior desarrollo y consolidación en el Derecho Internacional de los Derechos Humanos. Este derecho sin embargo, es producto de una dinámica histórica relativamente reciente, caracterizada por la lucha para prevenir las graves consecuencias de la violencia como forma de mantener, recuperar o conseguir el poder. Sus raíces se encuentran en el DIH y su emergencia está relacionada con la necesidad de las familias de conocer la suerte corrida por sus seres queridos desaparecidos durante y con ocasión de los conflictos armados. Con el desarrollo de la jurisprudencia

y doctrina internacionales de Derechos Humanos, fue configurándose un concepto mucho más amplio sobre el derecho a la verdad, que hoy en día comprende el derecho de las víctimas y sus familiares a conocer la verdad frente a las graves violaciones de Derechos Humanos cometidas, las circunstancias específicas y la identidad de los responsables y partícipes, así como sus motivaciones.

Este derecho ha venido cobrando cada vez mayor importancia en el contexto del Derecho Internacional, pues se trata además de una reivindicación social, resultado de las luchas históricas de mitad del siglo XX; es por esto importante entender que en este proceso en el que se ha venido configurando su naturaleza jurídica, las víctimas han tenido un papel preponderante, pues son ellas, a través de sus reclamos y los de sus familiares, las que han impulsado su consagración como un derecho autónomo e inalienable. Por otra parte, la verdad se ha convertido en un elemento necesario en el proceso social de construcción de memoria colectiva, así como un elemento esencial para la prevención de nuevos crímenes.

El derecho a la verdad tiene también un importante punto de inicio en el ámbito del derecho penal, en tanto en el desarrollo del juicio, se ejecutan un conjunto de acciones metodológicas orientadas a encontrar la verdad a partir de la evaluación de las pruebas. La búsqueda de la verdad en este contexto, se concretiza en el esclarecimiento de los hechos, y constituye un elemento 
fundamental en el contexto judicial. Aunque en el marco de los procesos penales individuales, el resultado final es siempre el mismo, el caso se gana o se pierde dependiendo de si se convence, o no al juez 0 al jurado de la culpabilidad o la inocencia del acusado. La verdad jurídica, desde esta óptica, es tan solo un producto secundario de un mecanismo de solución de diferencias.

Otra cuestión ocurre con el derecho a la verdad en el marco de los procesos donde se pretende procesar crímenes internacionales, contexto en el cual la verdad jurídica adquiere una importancia primaria. Al respecto, Yasmin Naqvi (2006), considera que este producto secundario adquiere una mayor relevancia cuando afirma:

La importancia de ese producto secundario que es la verdad jurídica ha asumido una nueva dimensión, debido, sin duda alguna, a los especiales objetivos fijados para el derecho penal internacional. Esos objetivos van mucho más allá de la mera determinación de la culpabilidad o la inocencia de algunos individuos, y pueden abarcar desde fines elevados, como contribuir al "restablecimiento y mantenimiento de la paz" ${ }^{1} 0$ al "proceso de reconciliación nacional" ${ }^{2}$, hasta luchar contra la impunidad, disuadir o prevenir con respecto a violaciones futuras, satisfacer las necesidades de las víctimas y hacer valer sus derechos, eliminar del escenario político a actores políticos peligrosos, restablecer el estado de derecho y reafirmar el principio de legalidad. Los objetivos también abarcan el efecto simbólico y ritual que produce el juicio penal en comunidades divididas, y permiten desplazarse de la culpa de la comunidad hacia la responsabilidad individual, reconstruir identidades nacionales a partir de interpretaciones del pasado a través del análisis y de procesos jurídico penales, y dejar constancia de los hechos históricos con un sello jurídico. (Naqvi, 2006, p.2)

Por otra parte, se debe reconocer la importancia de los tribunales penales internacionales tanto para la ex Yugoslavia como para Ruanda, en relación con la conformación de un concepto

\footnotetext{
${ }^{1}$ Considerando 9 del preámbulo de la resolución del Consejo de Seguridad 808 (1993), del 22 de febrero de 1993, sobre el establecimiento del Tribunal Penal Internacional para la ex Yugoslavia.

2 Considerando 7 de la resolución del Consejo de Seguridad 955 (1994), del 8 de noviembre de 1994, sobre el establecimiento del Tribunal Penal Internacional para Ruanda.
} 
jurídico de derecho a la verdad, así como la importancia de los denominados juicios de Nuremberg ${ }^{3}$ con respecto a la estructuración, fundamentación y metodología de procesos orientados a la reconstrucción de la verdad histórica y la memoria colectiva. De acuerdo a lo concluido por Louis Joinet "la defensa jurídica del derecho a la memoria fue uno de los objetivos fundamentales de los autores del Estatuto del Tribunal Penal Militar Internacional de Nuremberg" (Naciones Unidas, en: Comisión Colombiana de Juristas, 2012, p.16).

Una de las cuestiones que llama la atención y que debemos establecer frente a la génesis y evolución del derecho a la verdad, es que en los juicios de Nuremberg, a pesar de que uno de sus objetivos fundamentales fue la búsqueda de la verdad, no incluyeron nunca en sus estatutos la expresión "Derechos Humanos", por lo que podríamos concluir que el concepto jurídico de derecho a la verdad, no proviene exclusivamente del ámbito de los Derechos Humanos o del DIH como suele creerse. El derecho a la verdad, su nacimiento y evolución estaría inserto en los objetivos más amplios del derecho penal internacional, dentro de los cuales se encuentran entre otros, el de restablecer y mantener la paz. Esto, en tanto al exponer la verdad, las sociedades son capaces de prevenir la repetición de sucesos similares; facilitar los procesos de reconciliación de comunidades escindidas4; contribuir a erradicar la impunidad, porque saber la verdad sobre la identidad de los responsables de violaciones conduce a la rendición de cuentas, reconstruir las identidades nacionales fomentando la unidad de los países a través del diálogo sobre la historia común, y dejar constancia de los hechos históricos, porque la verdad sobre lo que sucedió puede ser objeto de un debate abierto y vigoroso en el tribunal, lo que fortalece la credibilidad de las pruebas aceptadas en el proceso penal.

El derecho a la verdad, como concepto jurídico, estaría igualmente ligado a la evolución de conceptos como crímenes graves, crímenes de lesa humanidad y graves violaciones a los Derechos Humanos, al igual que está determinado por la naturaleza compleja conforme la cual se desarrollan los conflictos armados y las situaciones de violencia.

\footnotetext{
${ }^{3}$ Los juicios o procesos de Nuremberg fueron un conjunto de procesos jurisdiccionales emprendidos por la iniciativa de las naciones aliadas vencedoras al final de la Segunda Guerra Mundial, en los que se determinaron y sancionaron las responsabilidades de dirigentes, funcionarios y colaboradores del régimen nacionalsocialista de Adolf Hitler en los diferentes crímenes y abusos contra la humanidad cometidos en nombre del tercer Reich Alemán a partir del 1 de septiembre de 1939.

${ }^{4}$ Decreto Supremo $n^{0} 355$, por el que se establece la Comisión Nacional de Verdad y Reconciliación de Chile: "Solo sobre la base de la verdad será posible satisfacer las exigencias elementales de la justicia y crear las condiciones indispensables para alcanzar una efectiva reconciliación nacional"
} 
En el contexto latinoamericano, contrario a los procesos de Nuremberg y a los tribunales penales internacionales, el derecho a la verdad adquiere una connotación más centrada en el ámbito del Derecho Internacional de los Derechos Humanos. Mientras que en Europa su fuente está determinada más en el desarrollo del derecho penal internacional, en Latinoamérica, debido a la particularidad de las situaciones de violencia socio-política determinada por regímenes dictatoriales y autoritarios, del Cono Sur y Centro América, su desarrollo está ligado a investigaciones adelantadas por comisiones y grupos de trabajo que en el contexto del sistema regional de protección de los Derechos Humanos fortalecieron y fundamentaron conceptualmente el derecho a la verdad.

Tal es el caso del Grupo de Trabajo ad hoc sobre la Situación de los Derechos Humanos en Chile, creado en 1975. Este Grupo de Trabajo planteó la cuestión del derecho de los familiares de desaparecidos a conocer la suerte y el paradero de los desaparecidos, y constituye el primer precedente en el marco del Sistema de las Naciones Unidas (SNU). El trabajo realizado por este grupo se fundamentó en el Derecho Internacional Humanitario, particularmente en el artículo 32 del Protocolo I de los Convenios de Ginebra. A partir de las conclusiones de ese trabajo se comienza a establecer la relación, entre el derecho a conocer la suerte y el paradero de los desaparecidos, con el deber del Estado de investigar y garantizar, propios del derecho a un recurso judicial efectivo.

En razón a la importancia y los resultados de los trabajos del Grupo de Trabajo en mención, la Comisión de Derechos Humanos de las Naciones Unidas, decidió crear en 1980 el Grupo de Trabajo sobre Desapariciones Forzadas o Involuntarias, el cual abordó la cuestión del derecho a la verdad de los familiares de las víctimas de desaparición forzada y resultó de tanta importancia para la Comisión de Derechos Humanos de las Naciones Unidas que su mandato ha sido renovado hasta la fecha. A través de sus informes, el Grupo de Trabajo creado por la Organización de las Naciones Unidas (ONU) ha desarrollado la importancia del derecho a la verdad, hasta considerarlo como un derecho autónomo y ha fundamentado su relación con otros derechos, como el derecho a la información, el derecho a la vida familiar y a la salud. En el documento denominado "Comentario general sobre el derecho a la verdad en relación con las desapariciones forzadas" (2011), se reitera la existencia del derecho a la verdad como un derecho autónomo, se reafirma que el derecho a la verdad existe en el ámbito del Derecho Internacional pues es una práctica aceptada por los Estados, cuya fuente está determinada en la jurisprudencia y en distintos mecanismos como las comisiones de la verdad. Se reconoce su 
dimensión individual pero también colectiva, y su importancia frente a la no repetición de las violaciones, señalando que:

"El derecho a la verdad es un derecho tanto colectivo como individual. Toda víctima tiene derecho a conocer la verdad sobre las violaciones que le afectan, pero la verdad debe comunicarse también a toda la sociedad como "una salvaguardia fundamental contra la repetición de tales violaciones". (Comentario general, 2011, p. 28).

En este proceso de surgimiento y consolidación del derecho a la verdad, jugaron un papel fundamental los grupos de trabajo referidos anteriormente, así como el Comité de Derechos Humanos de la ONU, la Comisión Interamericana de Derechos Humanos (CIDH) y la Corte Interamericana de Derechos Humanos (Corte IDH o Corte Interamericana). Más adelante se abordarán con mayor profundidad los aportes de cada uno de estos grupos, así como el derecho a la verdad desde los ámbitos del sistema universal y regional de protección de los Derechos Humanos.

Resulta de suma importancia entender la forma como la verdad se ha convertido en un elemento fundamental en los procesos de postconflicto, y cómo esta ha venido adquiriendo un matiz jurídico que hoy se traduce en lo que se denomina derecho consuetudinario, o costumbre internacional de los Estados. Sin embargo, el concepto de derecho a la verdad está sujeto a un desarrollo histórico que se complejiza en sus diferentes dimensiones, y el cual debe ser abordado no solo como categoría jurídica sino como elaboración social e histórica.

\subsection{El derecho a la verdad en el Derecho Internacional Humanitario}

El DIH es el derecho que se encuentra establecido en los cuatro convenios de Ginebra de 1949 y de los cuales son parte la mayoría de los Estados, incluyendo a Colombia. Estos cuatro convenios han sido complementados con los protocolos adicionales de 1977 relativos a la protección de las víctimas en los conflictos armados, así como con otros tratados en los cuales se regulan cuestiones concernientes al uso de armas y algunas tácticas militares. El Derecho Internacional Humanitario regula las cuestiones inherentes a los conflictos armados, tanto internacionales como de carácter interno o internacionalizado. Sus dos objetivos fundamentales son proteger a las personas 
que no participan de las hostilidades e imponer restricciones sobre medios de guerra, tácticas militares y medios para hacer la guerra.

Las fuentes consultadas, suelen ubicar históricamente las raíces del derecho a la verdad, en este ámbito del derecho, y surge con el ánimo de proteger a los familiares de personas desaparecidas durante los conflictos armados. El objetivo fundamental y además explícitamente reconocido, es garantizar el derecho a la verdad de los familiares de víctimas de desaparición forzada, así como entregar información sobre la suerte y el paradero de los combatientes desaparecidos en combate 0 en poder del enemigo, con el fin de mitigar la angustia de sus familiares por no conocer el destino de sus seres queridos (Orentlicher, 2004, párr.14). Todo lo anterior ha sido una preocupación central del DIH y el derecho a la verdad se convirtió en un instrumento jurídico determinante en todas las discusiones.

A partir de las dos primeras Conferencias Internacionales, de lo que más adelante sería el Comité Internacional de la Cruz Roja (CICR), celebradas en París y Berlín en 1867 y $1869^{5}$ respectivamente, se constituyeron los primeros abordajes sobre el derecho a la verdad en relación con los combatientes desaparecidos. Posteriormente varios tratados e instrumentos internacionales abordaron la cuestión del derecho a la verdad6. Los Convenios de Ginebra de 1949 incorporaron varias disposiciones que imponen obligaciones a las partes beligerantes para responder a estos problemas. En particular los artículos 16 y 17 del Convenio de Ginebra para aliviar la suerte que corren los heridos y los enfermos de las fuerzas armadas en campaña (Convenio I) y el artículo 122 y siguientes del Convenio de Ginebra relativo al trato debido a los prisioneros de guerra (Convenio III), así como el artículo 136 y siguientes relativos a la protección debida a las personas civiles en tiempos de guerra (Convenio IV).

\footnotetext{
${ }^{5}$ En estas reuniones se afirmaron los principios del Derecho Internacional Humanitario y se asignaron las funciones del Comité Internacional de la Cruz Roja.

${ }^{6}$ Entre otros, Manual de Oxford sobre las Leyes de la Guerra Terrestre del 9 de septiembre de 1880 (art. 20); Convención (II) relativa a las Leyes y Costumbres de la Guerra Terrestre y su Reglamento relativo a las Leyes y Costumbres de la Guerra Terrestre, La Haya, del 19 de julio de 1899 (art. 14); Convenio para el mejoramiento de la suerte de los militares heridos o enfermos en los ejércitos en campaña, Ginebra, del 6 de julio de 1906, (art. 3 y 4); Convención (IV) relativa a las Leyes y Costumbres de la Guerra Terrestre y su Reglamento relativo a las Leyes y Costumbres de la Guerra Terrestre, La Haya, del 18 de octubre de 1907 (art. 14); Convención (X) para la adaptación de los principios del Convenio de Ginebra a la Guerra Marítima, La Haya, del 18 de octubre de 1907 (art. 16 y 17) y convenio para el mejoramiento de la suerte de los militares heridos o enfermos en los ejércitos en campaña, Ginebra, del 27 de julio de 1929.
} 
Con la adopción en 1977 del Protocolo Adicional a los Convenios de Ginebra del 12 de agosto de 1949 relativo a la protección de las víctimas de los conflictos armados internacionales (Protocolo I), aparecería la primera norma convencional que explícitamente reconoce la existencia del "derecho que le asiste a las familias de conocer la suerte de sus miembros" desaparecidos (artículo 32). Este derecho sería reconocido expresamente como un "principio general" del Derecho Internacional Humanitario en cuanto a personas desaparecidas. Así lo reiteró la XXV Conferencia Internacional del CICR, celebrada en 1986, en su Resolución XIII (Comisión Colombiana de Juristas, 2012).

El derecho a la verdad, comenzó como un derecho de los familiares de las víctimas de desaparición en el marco de los conflictos armados y más adelante pasó a ser reconocido como una norma del Derecho Internacional Humanitario, hasta terminar abarcando todas las infracciones al DIH. El Comité Internacional de la Cruz Roja concluyó que el derecho a la verdad es una norma del derecho internacional consuetudinario ${ }^{7}$ aplicable tanto a los conflictos armados internacionales como a los internos, de modo que cada parte del conflicto debe tomar todas las medidas factibles para conocer el paradero de las personas presuntamente desaparecidas a raíz de un conflicto armado. No hay que olvidar que el DIH es aplicable en Colombia ${ }^{8}$ y se encuentra incluido en el marco general de la justicia transicional compuesto fundamentalmente por la Ley 975 de 2005 o Ley de Justicia y Paz, el marco jurídico para la paz, así como es incorporado en la Ley 1448 de 2011 a través del artículo 3 que realiza la definición de víctima para todos los efectos de la ley.

Finalmente y una vez sistematizada la jurisprudencia de los órganos internacionales de protección de los Derechos Humanos, el Comité Internacional de la Cruz Roja concluye que el derecho a la verdad desborda delitos como la desaparición y abarca todas las infracciones al DIH, y está comprendido implícitamente en la obligación de reparación de los Estados por dichas violaciones. Este incluye, no sólo el derecho a saber, sino que abarca además, la investigación y el enjuiciamiento a los responsables (Henckaerts \& Doswald-Beck, en: Comisión Colombiana de Juristas, 2012, p.20).

\footnotetext{
${ }^{7}$ El derecho internacional consuetudinario está compuesto por normas que resultan de "una práctica general aceptada como derecho", cuya existencia es independiente del derecho convencional. El Derecho Internacional Humanitario consuetudinario (DIH consuetudinario) reviste una importancia fundamental en los conflictos armados contemporáneos, porque llena las lagunas del derecho convencional tanto en lo que respecta a los conflictos armados internacionales como no internacionales, por lo que fortalece de ese modo la protección de las víctima.

${ }^{8}$ En cuanto a la incorporación de estos instrumentos internacionales en el orden jurídico interno resulta importante precisar que los convenios de Ginebra fueron adoptados mediante la ley $5^{\text {a }}$ de 1960 (Diario Oficial 30.318), ratificados el 8 de noviembre de 1961 y promulgados mediante el decreto 1016 de 1990 (Diario oficial 39.360).
} 


\subsection{El derecho a la verdad en el Derecho Internacional de los Derechos Humanos}

El Derecho Internacional de los Derechos Humanos (DIDH) está compuesto por toda una serie de convenciones y tratados internacionales, cuyo fin es proteger los Derechos Humanos que son reconocidos en la Declaración Universal de los Derechos Humanos (1948). El DIDH tiene una composición de tipo universal, que se encuentra establecida en la denominada Carta de Derechos Humanos, la cual está integrada por un conjunto de convenciones aprobadas por la Asamblea General de la ONU. De igual manera, el Derecho Internacional de los Derechos Humanos tiene una manifestación de tipo regional, a partir de los cuatro sistemas de protección de Derechos Humanos: el sistema Universal, el sistema Europeo, sistema Americano y el sistema Africano. El sistema Americano o Interamericano lo integran la Declaración Americana de Derechos del Hombre o Carta de Bogotá (1948) y la Convención Americana sobre Derechos Humanos (1969), cuyos órganos de aplicación son la Comisión Interamericana de Derechos Humanos y la Corte Interamericana de Derechos Humanos.

Uno de los hechos más representativos que influyó de manera directa en la evolución de este derecho fue la práctica generalizada y sistemática de la desaparición forzada en los países del Cono Sur, ejercida por los diferentes regímenes dictatoriales: Argentina 1976-1983; Uruguay 1973-1984; Chile 1973-1990; Bolivia 1971-1978 y Paraguay 1974-1989. Debido a las reclamaciones de las víctimas y familiares en medio del contexto dictatorial, el derecho a la verdad comenzó a recibir mayor atención por parte de los órganos internacionales de Derechos Humanos y fue configurándose el denominado corpus iuris del mismo, a partir del desarrollo al interior de los diferentes sistemas regionales de protección.

El contexto de violaciones generalizadas y sistemáticas que se presentó en el territorio latinoamericano, sirvió como detonante para la fundamentación jurídica de un derecho a la verdad más amplio. Este proceso de amplitud se caracteriza por un conjunto de estudios que recomendaron hacer extensiva la obligación de garantizar el derecho a la verdad en tiempos de paz. El camino para la fundamentación jurídica de extender el derecho a la verdad a otros contextos distintos a los de conflicto armado tal como se venía insistiendo a partir de los convenios de Ginebra y la interpretación de los mismos por parte del CICR, se realizó vía el sistema universal de protección. De hecho, fue a 
partir del trabajo de los relatores especiales de la ONU ${ }^{9}$ que se consideró que el derecho a la verdad constituye norma de derecho internacional consuetudinario.

Cómo se mencionó al inicio de este capítulo, se destacan tres grupos de trabajo que surgieron en el marco de los contextos de violencia producto de las dictaduras del Cono Sur, particularmente como respuesta a la práctica de la desaparición forzada de los regímenes dictatoriales de Chile y Argentina y que constituyeron precedentes claves para el desarrollo de un concepto jurídico más amplio sobre el derecho a la verdad.

$\checkmark$ Grupo de Trabajo ad hoc sobre la Situación de los Derechos Humanos en Chile (1975)

$\checkmark$ Grupo de Trabajo sobre desapariciones forzadas o involuntarias (1980)

$\checkmark$ Subcomisión de Prevención de Discriminaciones y Protección a las Minorías de las Naciones Unidas (1970)

Los estudios realizados por estos grupos, que serán ampliados más adelante, continuaron utilizando como base jurídica los artículos 32 y 33 del Protocolo I de los Convenios de Ginebra, sin embargo, constituyen piedras angulares para la conformación de un derecho a la verdad que se extendería a otras violaciones como las ejecuciones extrajudiciales y la tortura. A continuación se realiza una síntesis de los aportes de cada uno de los grupos de trabajo, que se ubican por su composición y objetivos en el contexto del Sistema de las Naciones Unidas. También se sintetizan los aportes de la Comisión de Derechos Humanos de la Organización de la ONU y la Oficina del Alto Comisionado de las Naciones Unidas para los Derechos Humanos (OACNUDH) y el Secretario General.

\subsubsection{El Grupo de Trabajo ad hoc sobre la Situación de los Derechos Humanos en Chile $e^{10}$}

Este grupo de trabajo se conformó en el marco del Sistema Universal de Protección de los Derechos Humanos y constituye el primer precedente en relación con el derecho a la verdad, en el

\footnotetext{
${ }^{9}$ Entre otros, informe de la reunión de expertos sobre derechos no expuestos a suspensión en situaciones de emergencia y circunstancias excepcionales, celebrada en Ginebra del 17 al 19 de marzo de 1995. Se puede encontrar en el informe del Relator Especial sobre la cuestión de los Derechos Humanos y los estados de excepción de la ONU. Documento de las Naciones Unidas E/CN.4/Sub. 2/1995/20, Anexo I.

10 Este grupo fue conformado a raíz de las denuncias en relación con los casos de desapariciones forzadas que se presentaron en Chile desde el golpe militar en 1973, el grupo conformado en el marco de la Comisión de Derechos Humanos de la ONU y en articulación con la Comisión Interamericana de Derechos Humanos, se conformó en 1974 con
} 
Sistema de Naciones Unidas y el ámbito interamericano. En su informe se plantea el derecho de los familiares de desaparecidos a conocer la suerte y el paradero de los desaparecidos, así como se reafirma el derecho de los miembros de la familia a conocer la suerte de los desaparecidos, establecido en el DIH además subrayó el deber del Estado de investigar con eficacia los casos de desaparición forzada. Este Grupo de Trabajo abordó el derecho a la verdad en función de los preceptos que se encuentran incluidos en el artículo 32 del Protocolo I de los Convenios de Ginebra. Sin embargo, a partir de su trabajo es cuando comienza a realizarse un marco de relación entre el derecho a la verdad y otro tipo de derechos de las víctimas como el derecho a la justicia constituido en este caso particular por el llamado a los Estados a respetar el deber de investigar las violaciones de los Derechos Humanos.

\subsubsection{El Grupo de Trabajo sobre Desapariciones Forzadas o Involuntarias ${ }^{11}$}

Los resultados de este Grupo de Trabajo son de suma importancia para la comprensión del derecho a la verdad, por cuanto además de reafirmar el derecho de las familias a conocer la suerte corrida por sus miembros víctimas de desaparición forzada, llegaron a la conclusión de que el derecho a la verdad era un derecho autónomo. El Grupo concluyó que la ausencia de información a las familias sobre la suerte y el paradero de las personas desaparecidas, violaba los derechos a la vida familiar y a la salud. Además entregó sus resultados a la Comisión de Derechos Humanos de la ONU, manifestando la importancia del derecho a la verdad y definiéndolo como el derecho a conocer los progresos y resultados de una investigación, la suerte y el paradero de las personas desaparecidas y las circunstancias de la desaparición, así como la identidad del autor o los autores de la desaparición.

Este Grupo de Trabajo ha aportado al desarrollo del derecho a la verdad, subrayando su importancia en relación con el delito de la desaparición forzada. Desde 1980, el Grupo viene emitiendo

el fin de emitir un informe sobre la situación de los Derechos Humanos en ese país. El primer informe se presentó el 4 de febrero de 1976 e ilustró por primera vez un caso de desaparición forzada cuya víctima fue un ciudadano de origen Francés detenido en su domicilio en Santiago de Chile en 1974.

11 Este grupo de trabajo, creado en 1980 por la Comisión de Derechos Humanos de la ONU, examina casos de desaparición forzada. Sin embargo, únicamente analiza aquellos casos que se ajustan a la definición de desaparición forzada establecida en la Declaración de la ONU para la protección de todas las personas frente a desapariciones forzadas, es decir, solamente los casos de desapariciones forzadas en las que un Estado podría considerarse responsable. Es importante tener en cuenta que el grupo de trabajo no examina las desapariciones forzadas llevadas a cabo por grupos irregulares o insurrectos que luchan contra las fuerzas del gobierno dentro del territorio del Estado en cuestión. 
informes anuales, por medio de los cuales entrega recomendaciones a los diferentes países donde realiza sus visitas, incluido Colombia; informa sobre la situación en cada país; entrega datos sobre la metodología utilizada y genera recomendaciones tanto a los gobiernos como al Consejo de Derechos Humanos de la ONU.

\subsubsection{La Subcomisión de Prevención de Discriminaciones y Protección a las Minorías ${ }^{12}$}

El trabajo realizado por esta subcomisión es de suma importancia para entender el derecho a la verdad con todos los componentes que tiene actualmente. Durante el trabajo de esta subcomisión, América Latina estaba pasando por un periodo marcado por las dictaduras, gobiernos autoritarios y conflictos internos, contexto en cual se cometieron torturas, desapariciones, ejecuciones extrajudiciales, detenciones ilegales y homicidios en diversos países, incluido Colombia. En sus diferentes documentos esta subcomisión reconoció el derecho de las víctimas de personas desaparecidas, incluso en 1985 Louis Joinet, en su informe final concluyó que "en el caso de las víctimas de desapariciones forzadas o involuntarias, se reconoce cada vez más a las familias el derecho a saber" (Naciones Unidas, 1985, p.22).

El estudio de Louis Joinet abarcó las leyes de amnistía y el papel que desempeñan en la salvaguardia y la promoción de los Derechos Humanos (Comisión Colombiana de Juristas, 2012), abordando la cuestión de la impunidad y su relación con el derecho a la verdad. El estudio constituye un precedente jurídico político muy importante, puesto que se introduce la locución "derecho a saber", y se vincula el derecho a la verdad con el fenómeno de la impunidad, lo que le otorga un matiz no solo de naturaleza jurídica sino también una argumentación desde el discurso político. Por otra parte, en este mismo contexto se comenzarían a estructurar los instrumentos jurídicos más importantes para la protección y la garantía del derecho a la verdad. Es en este periodo (1986-1991) en el cual el Relator Especial sobre el derecho a la reparación Theo Van Boven destacaría la relación entre el derecho a

\footnotetext{
12 Esta Subcomisión fue creada en 1947 y mantuvo ese nombre hasta 1999 cuando lo cambio por "Subcomisión de Promoción y Protección de los Derechos Humanos".
} 
la verdad y los derechos a interponer recursos y obtener reparación por graves violaciones a los Derechos Humanos ${ }^{13}$.

Louis Joinet abordó la cuestión del derecho a la verdad de las víctimas de graves violaciones de Derechos Humanos y de sus familiares, realizó una serie de estudios que culminaron en 1997 con la entrega del proyecto Conjunto de principios para la protección y la promoción de los Derechos Humanos mediante la lucha contra la impunidad ${ }^{14}$. Este documento fue adoptado por la Subcomisión de Prevención de Discriminaciones y Protección a las Minorías de las Naciones Unidas, ese mismo año. Posteriormente fue objeto de una revisión y actualización y publicado con el título Conjunto de principios actualizado para la protección y la promoción de los Derechos Humanos mediante la lucha contra la impunidad ${ }^{15}$. Debido a su importancia como instrumento jurídico fundamental en cuanto al derecho a la verdad, realizaremos un análisis de su contenido en un capitulo posterior.

Una de las cuestiones relacionadas con el desarrollo del derecho a la verdad que es producto de este estudio, es la locución "derecho a saber", el experto consideró que el derecho a la verdad o derecho a saber, existe como tal y tiene su origen en la lucha contra la impunidad, la cual tiene su origen en la necesidad de que se haga justicia. (Comisión Colombiana de Juristas, 2012, p. 27).

En este sentido, el derecho a saber junto a la sanción a los responsables y la reparación a las víctimas constituyen los pilares fundamentales de la justicia y es imprescindible considerarlos de forma integral e interdependiente. De esta forma, es durante el trabajo de esta Subcomisión cuando el derecho a la verdad o derecho a saber cómo fue establecido por el experto internacional, comienza a complejizarse como concepto jurídico, se vincula con el derecho a la reparación de las víctimas de graves violaciones a los Derechos Humanos, así como con el fenómeno de la impunidad y se establece como un derecho de carácter inalienable. Es este el momento en el cual el derecho a la verdad se vincula con el derecho a la reparación de las

\footnotetext{
13 Documento de las Naciones Unidas E/CN.4/Sub.2/1993/8, E/CN.4/1997/104 y E/CN.4/2000/62 y el proyecto de "principios y directrices básicos sobre el derecho de las víctimas de violaciones de las normas internacionales de Derechos Humanos y del Derecho Internacional Humanitario a interponer recursos y obtener reparaciones.

${ }_{14}$ Documento de Naciones Unidas E/CN.4/Sub.2/1997/ Rev.1, Anexo I.

${ }^{15}$ Reproducido en el documento de la Comisión de Derechos Humanos de la ONU. E/CN.4/2005/102/ Add.1 de 8 de febrero de 2005.
} 
víctimas de graves violaciones a los Derechos Humanos y por tanto, se convierte en un elemento sustancial en el marco de la lucha contra la impunidad.

\subsubsection{Comisión de Derechos Humanos de la Organización de las Naciones Unidas}

En el contexto de esta comisión, se destaca el trabajo realizado por la experta independiente Diana Orentlicher, quien fue designada por el Secretario General de la ONU a solicitud de la antigua Comisión de Derechos Humanos, con el fin de elaborar una versión actualizada del Conjunto de Principios para la Protección y la Promoción de los Derechos Humanos mediante la Lucha contra la Impunidad. En su trabajo Orentlicher concluyó lo siguiente:

La evolución reciente del derecho internacional ha confirmado categóricamente la validez del Conjunto de Principios (incluidos los principios sobre el derecho a la verdad). Algunos de ellos abarcan principios de los tratados de Derechos Humanos y del derecho consuetudinario que ya estaban bien asentados en 1997; otros se han visto ratificados por evoluciones más recientes del derecho internacional que se resumen en este estudio. Los principios han constituido, de por sí, un marco influyente para las medidas nacionales de lucha contra la impunidad. (Orentlicher 2004, párr. $65)^{16}$

En este mismo informe Orentlicher, resalta el gran desarrollo del derecho a saber la verdad, el cual, según ella, se ha reafirmado a partir de los instrumentos de Derechos Humanos elaborados por diferentes órganos creados en virtud de tratados de Derechos Humanos. La experta concluyó, que el derecho a la verdad está ampliamente reconocido por la jurisprudencia de Derechos Humanos tanto de carácter universal como regional. En su informe subrayó la relación estrecha que existe entre el derecho a la verdad y el deber del Estado de realizar investigaciones eficaces sobre las violaciones de Derechos Humanos, así como con el derecho de los familiares a ser informados sobre los resultados y obtener reparación.

En el contexto de esta Comisión, el Relator Especial, Louis Despouy, sobre la independencia de los magistrados y abogados, en el informe sobre su misión a Perú, concluyó que "las leyes de

\footnotetext{
${ }^{16}$ Estudio independiente, con inclusión de recomendaciones, sobre las mejores prácticas, para ayudar a los Estados a reforzar su capacidad nacional con miras a combatir todos los aspectos de la impunidad.
} 
amnistía peruanas privan a las víctimas de su derecho a conocer la verdad" (en: Comisión Colombiana de Juristas, 2012, p.29). En esta misma línea, Despouy consideró que la violación al derecho a conocer la verdad sobre los crímenes ocurridos fomentaba la impunidad, estableciendo una doble utilidad en el derecho a saber, primero en relación con la administración de justicia y segundo, en relación con el proceso de reparación:

Así, desde el punto de vista del derecho a la justicia, la verdad es a la vez un requisito para determinar responsabilidades y el primer paso del proceso de reparación. La instancia judicial, debidamente substanciada, es el medio para alcanzar los altos valores de la verdad y la justicia. En esta perspectiva, la administración de justicia con independencia e imparcialidad constituye un instrumento de gran importancia para satisfacer el derecho a la verdad. (Despouy, en Comisión Colombiana de Juristas, 2012, pp.29-30)

Los trabajos realizados por Orentlicher y Despouy nos permiten ver cómo el derecho a la verdad evolucionó en el Derecho Internacional de los Derechos Humanos. Estos establecieron una argumentación sólida que permite considerar el derecho a la verdad como un derecho autónomo, inalienable y sobre todo como norma de derecho internacional de carácter consuetudinario, elemento sustancial para la lucha contra la impunidad e imperativo elemental para reparar integralmente a las víctimas de graves violaciones a los Derechos Humanos. Contrario los trabajos realizados por los Grupos de Trabajo mencionados, en los trabajos de Orentlicher y Despouy sobre el derecho a la verdad, se sitúa como un derecho autónomo con relación estrecha con otros derechos como el derecho a la justicia, a la información, a saber, y a la reparación integral. Precisamente su relación con el derecho a la reparación de las víctimas de graves violaciones a los Derechos Humanos será el corolario de su camino evolutivo y por tanto un elemento clave en relación con los objetivos propuestos en esta investigación.

\subsubsection{Oficina del Alto Comisionado de las Naciones Unidas para los Derechos Humanos y Secretario General de las Naciones Unidas.}

La OACNUDH ha afirmado en múltiples ocasiones el valor que tiene la verdad tanto para las víctimas de graves violaciones a los Derechos Humanos como para la sociedad en su conjunto. Esta Oficina se ha manifestado en relación con las comisiones de la verdad, recordando el derecho de las 
naciones a conocer la verdad sobre los hechos del pasado: "[p]ara evitar que las violaciones se repitan, el ejercicio íntegro y efectivo del derecho a la verdad es esencial" (en: Comisión Colombiana de Juristas, 2012, p.32). De igual forma se pronunció sobre la situación de los Derechos Humanos en Colombia, particularmente sobre la negociación entre el Gobierno y los grupos paramilitares manifestando que

Se desarrolló sin que paralelamente exista un marco legal adecuado que garantizará el derecho a la verdad, a la justicia y a la reparación de las víctimas, y que no haya impunidad para los autores de crímenes de lesa humanidad y de guerra (Informe de la Alta Comisionada, 2005, p. 5).

Igualmente, la OACNUDH ha realizado una labor orientada a sistematizar la evolución de la jurisprudencia y doctrina internacionales de Derechos Humanos y las prácticas nacionales, así como las normas y los estándares internacionales sobre el derecho a la verdad, a través de varios estudios ${ }^{17}$ que representan el corpus iuris internacional existente y constituyen un valioso instrumento para un cabal conocimiento del derecho a la verdad, su base jurídica así como su alcance, naturaleza y contenido.

Por otra parte, el Secretario General de la ONU también ha reafirmado la importancia del derecho a la verdad, y su estrecha relación con el derecho a la justicia en tanto el saber la verdad impide la repetición de los hechos (Ban Ki Mon. 2016, 24 mar). De la misma forma y en el marco de la apertura del proceso de negociación entre el Gobierno de Colombia y grupos paramilitares, fue enfático en reafirmar "la necesidad de respetar plenamente el derecho a la verdad, a la justicia y a las reparación de las víctimas, especialmente en el marco de este tipo procesos que no admiten adminstias generales o impunidades de facto" (Annan, Kofi, fechado 01.07.2004).

\footnotetext{
${ }^{17}$ Estudios sobre el derecho a la verdad - Informe de la Oficina del Alto misionado de las Naciones Unidas para los Derechos Humanos, documento E/CN.4/2006/91 de 9 de enero de 2006; El derecho a la verdad - Informe de la Oficina del Alto Comisionado de las Naciones Unidas para los Derechos Humanos, documento A/HRC/5/7 de 7 de junio de 2007; El derecho a la verdad - Informe de la Oficina del Alto Comisionado de las Naciones Unidas para los Derechos Humanos, documento A/HRC/12/19 de 21 de agosto de 2009; e informe de la Oficina del Alto Comisionado de las Naciones Unidas para los Derechos Humanos sobre el seminario de experiencias en materia de archivos como medio de garantizar el derecho a la verdad, documento A/HRC/17/21 de 14 de abril de 2011. Tomado de: Comisión Colombiana de Juristas, 2012, p. 31.
} 


\subsection{El Derecho a la verdad en el Sistema Interamericano de Derechos Humanos}

El derecho a la verdad no se encuentra explícitamente reconocido en los instrumentos interamericanos de Derechos Humanos. La génesis del derecho a la verdad en el contexto del Sistema Interamericano la podemos situar en el marco de su intervención frente a la grave situación de los Derechos Humanos en los países del Cono Sur y los contextos de impunidad que se presentaron en la región. Desde esta óptica, el derecho a la verdad nace como respuesta a la práctica de la desaparición forzada y a los contextos de violencia en medio de los cuales, los Estados no cumplieron con su papel de garantía y respeto de los Derechos Humanos. Así lo establece la CIDH en su reciente informe titulado "Derecho a la Verdad en América":

El derecho a la verdad ha surgido como respuesta frente a la falta de esclarecimiento, investigación, juzgamiento y sanción de los casos de graves violaciones de Derechos Humanos e infracciones al DIH por parte de los Estados. Es a través de los esfuerzos para combatir la impunidad que los órganos del sistema han desarrollado estándares regionales que dan contenido al derecho a la verdad, y los Estados y la sociedad civil han desarrollado enfoques e iniciativas para implementarlos en una amplia gama de conceptos. Asimismo, el derecho a la verdad constituye uno de los pilares de los mecanismos de justicia transicional. (CIDH, 2014, p.3).

El fundamento legal conforme al cual se inicia la construcción del concepto jurídico de derecho a la verdad en el Sistema Interamericano, sigue recayendo en las normas del DIH, así como en el Protocolo I de los Convenios de Ginebra, por tanto, se hace referencia al derecho de las familias a conocer la suerte que han corrido sus miembros, así como la obligación de los Estados de buscar a los desaparecidos en los conflictos armados. En el informe anual publicado en 1986, la Comisión Interamericana concluyó que "nada puede impedir a los familiares de los desaparecidos conocer lo que aconteció con sus seres más cercanos" (CIDH, 1986, p. 205).

Tanto la Comisión como la Corte Interamericana, a partir de casos contenciosos y de su labor de monitoreo y vigilancia de las situación de los Derechos Humanos en la región, abordaron la grave práctica de la desaparición forzada. No obstante, a partir de los pronunciamientos de la Comisión Interamericana y la jurisprudencia propia de la Corte, se evidencia una expansión progresiva en relación con el alcance del derecho a la verdad a otras violaciones de los Derechos Humanos, tales 
como las ejecuciones extrajudiciales y la tortura. Así mismo, fue precisando el alcance y contenido del derecho a la verdad. De acuerdo con el Informe Anual de la CIDH 1985-1986 y el caso No. 11/48, Monseñor Oscar Arnulfo Romero y Galdámez (El Salvador), respectivamente.

Inicialmente [el derecho a la verdad] fue definido como el "derecho a conocer la verdad de lo ocurrido, así como las razones y circunstancias en las que esos delitos llegaron a cometerse", la Comisión Interamericana de Derechos Humanos fue haciendo más explícito su contenido, en tanto este derecho implica "conocer la verdad integra, completa y pública sobre los hechos ocurridos, sus circunstancias específicas y quiénes participaron en ellos". (En: Comisión Colombiana de Juristas, 2012, p. 35)

La jurisprudencia de la Corte IDH, apoyada en los distintos informes, trabajos e instrumentos de la ONU 18 fue consolidando y ampliando el concepto jurídico de derecho a la verdad hasta establecerlo como una garantía cuya fuente se encuentra tanto en la Declaración Americana como en la Convención Americana. Tanto la Comisión como la Corte han establecido a través de su jurisprudencia, que el derecho a la verdad está vinculado de forma directa con los artículos XVIII y XXIV de la Declaración Americana, y los artículos 8 y 25 de la Convención Americana. De igual forma se ha vinculado en ciertos contextos facticos analizados por la Corte Interamericana y a solicitud de las víctimas, con el derecho de acceso a la información contemplado en el artículo IV de la Declaración Americana y el artículo 13 de la Convención Americana.

Por otra parte, tanto Corte como Comisión, reconocen la doble dimensión del derecho a la verdad, entendido como el derecho de las víctimas y sus familiares a conocer la verdad con respecto a los hechos que dieron lugar a las graves violaciones de los derechos humanos, así como a conocer

\footnotetext{
18 Comisión de Derechos Humanos, Informe de la Oficina del Alto Comisionado de las Naciones Unidas para los Derechos Humanos, Estudio sobre el derecho a la verdad, E/CN.4/2006/91, 9 de enero de 2006, párr. 8. En el caso de las ejecuciones extrajudiciales, inter alía, véase el Principio 9 de los "Principios relativos a una eficaz prevención e investigación de las ejecuciones extralegales, arbitrarias o sumarias", adoptados por el Consejo Económico y Social mediante Resolución 1989/65 de 24 de mayo de 1989 que establece: "se procederá a una investigación exhaustiva, inmediata e imparcial de todos los casos en que haya sospecha de ejecuciones extralegales, arbitrarias o sumarias, incluidos aquéllos en los que las quejas de parientes u otros informes fiables hagan pensar que se produjo una muerte no debida a causas naturales en las circunstancias referidas. Los gobiernos mantendrán órganos y procedimientos de investigación para realizar esas indagaciones. La investigación tendrá como objetivo determinar la causa, la forma y el momento de la muerte, la persona responsable y el procedimiento o práctica que pudiera haberla provocado". Así mismo, el "Manual sobre la prevención e investigación eficaces de las ejecuciones extralegales, arbitrarias o sumarias" adoptado en el año 1991, al señalar los propósitos de la indagación es descubrir la verdad acerca de acontecimientos que ocasionaron la muerte sospechosa de la una víctima". Tomado de: CIDH, 2014.
} 
la identidad de quienes participaron en ellos. Esto implica que el derecho a la verdad, acarrea la obligación de los Estados de esclarecer, investigar, juzgar y sancionar a las personas responsables de los casos de graves violaciones de Derechos Humanos, así como, dependiendo de las circunstancias de cada caso, garantizar el acceso a la información que repose en instituciones y fuerzas militares del Estado.

En este mismo sentido el derecho a la verdad tiene una dimensión colectiva, en el entendido en que hace parte del derecho que tiene la sociedad en su conjunto, de conocer las causas y circunstancias, las responsabilidades políticas, institucionales y sociales que permitieron la comisión de graves violaciones a los Derechos Humanos. Lo anterior, brinda a la sociedad la garantía de la no repetición de dichas atrocidades $(\mathrm{CIDH}, 1986, \mathrm{p} .86)$

La satisfacción de la dimensión colectiva del derecho a la verdad exige la determinación procesal de la más completa verdad histórica posible, lo cual incluye la determinación judicial de los patrones de actuación conjunta y de todas las personas que de diversas formas participaron en dichas violaciones y sus correspondientes responsabilidades. (CIDH, 2014, párr. 20)

En el Informe Anual de la Comisión Interamericana publicado en 1986, la Comisión estableció que:

Toda sociedad tiene el irrenunciable derecho de conocer la verdad de lo ocurrido, así como las razones y circunstancias en las que aberrantes delitos llegaron a cometerse, a fin de evitar que esos hechos vuelvan a ocurrir en el futuro (CIDH, 1986 p.86)

Los regímenes dictatoriales del Cono Sur y en general las situaciones violentas que se presentaron a lo largo y ancho del continente, generaron un alto número de víctimas. Los Estados, muchos de ellos aplicando la doctrina de la seguridad nacional y el enemigo interno, desplegaron diversos repertorios de violencia sobre grupos políticos, estudiantiles y líderes de oposición. Como forma de superar estas situaciones de violencia y avanzar hacia la consolidación democrática, en países como Guatemala, El Salvador, Honduras, Brasil, Argentina, Perú y Chile, se implementaron mecanismos de justicia transicional. Sin embargo, en gran medida, la implementación de estos mecanismos no resultó efectiva frente a la garantía del derecho a la verdad de las víctimas. Esta situación favoreció en algunos casos, procesos de mantenimiento de la impunidad sobre graves 
violaciones a los Derechos Humanos, restringiendo el acceso a la información, al esclarecimiento y a la verdad de las víctimas de graves crímenes y por tanto cubriendo con un manto de olvido grandes contextos de violencia social y política.

La situación de impunidad luego de la implementación de mecanismos de justicia transicional, el descontento de las víctimas y las demandas frente al incumplimiento de los estándares de justicia interamericanos, conllevó a que la Corte IDH entrara a analizar diversas situaciones, frente a las cuales responsabilizó a los estados por la violación de los derechos establecidos en la Convención Interamericana. Ante estas situaciones, la Corte entró a analizar la responsabilidad de los Estados en relación con el acceso a la justicia de las víctimas de graves violaciones a los derechos humanos, infracciones al derecho internacional humanitario y crímenes considerados por el Estatuto de Roma como de lesa humanidad.

En este contexto, a partir de su jurisprudencia, la Corte Interamericana fue estableciendo la relación entre el derecho a la verdad y la justicia transicional, reconociendo que en el marco de contextos transicionales "el logro de una verdad completa y veraz, imparcial y socialmente construida, compartida y legitimada es un elemento fundamental para la reconstrucción de la confianza ciudadana en la institucionalidad estatal" (CIDH, 1986, p.20). Igualmente se ha pronunciado respecto al establecimiento de comisiones de la verdad, frente a lo cual ha reconocido su importancia frente a la contribución y preservación de la memoria histórica, el esclarecimiento de hechos y la determinación de responsabilidades institucionales, sociales y políticas.

La Corte Interamericana también ha sido enfática en afirmar que: "las verdades históricas que a través de ese mecanismo se logren, no deben ser entendidas como un sustituto del deber del Estado de asegurar la determinación judicial de responsabilidades individuales o estatales por los medios jurisdiccionales correspondientes" (Corte I.D.H., Caso Zambrano Vélez y otros vs Ecuador, 2007, párr. 128). De igual forma reconoce la naturaleza complementaria de las comisiones de la verdad y reafirma que el sentido, alcance, potencialidades y límites particulares dependen del contexto en el que surgen, "y de los casos y circunstancias concretas que se analicen" (Caso Zambrano Vélez y otros vs Ecuador, 2007, párr.129). (Corte I.D.H., Caso Zambrano Vélez y otros vs Ecuador, 2007, párr. 129).

En este sentido, la Corte Interamericana le ha otorgado especial relevancia a los informes de comisiones de la verdad o en algunos casos de esclarecimiento histórico, dándole un valor 
fundamental como pruebas que resultaron fundamentales tanto para la determinación de los hechos, como de la responsabilidad internacional de los Estados que se han sometido a su jurisdicción. Este es el caso del Diario Militar vs Guatemala, donde el Estado guatemalteco, luego de un periodo de conflicto armado interno entre los años 1962 y 1996, implementó la Comisión para el Esclarecimiento Histórico como mecanismo de esclarecimiento de la verdad. En este caso, la Corte determinó basándose en los documentos de la Comisión, que: "las autoridades militares no han aportado de forma debida y oportuna información pertinente para esclarecer los hechos" (Corte I.D.H., Caso Diario Militar vs Guatemala, 2012, párr. 251).

El esclarecimiento de los hechos según la Corte Interamericana, es un instrumento fundamental para la garantía del derecho a la verdad, para esto los mecanismos que implementen los Estados, orientados al esclarecimiento de la verdad deben estar dotados, formal y sustancialmente, de las facultades y garantías adecuadas y necesarias para acceder a la documentación e información pertinente para investigar los hechos denunciados y obtener indicios o evidencias. Frente a la actuación de las autoridades estatales en estos mecanismos, la Corte destacó que "las autoridades estatales están obligadas a colaborar en la recaudación de pruebas para alcanzar los objetivos de la investigación y abstenerse de realizar actos que impliquen obstrucciones para la marcha del proceso investigativo" (Corte I.D.H., Caso Diario Militar vs Guatemala, 2012, párr. 251).

En este sentido, los representantes de las víctimas en el caso del Diario Militar alegaron, con base en los hechos, que la denegación de información por parte de las fuerzas militares a la CEH, constituye una violación del derecho autónomo a la verdad, el cual se configura en los artículos 8,13 y 25 de la Convención Americana. El Estado de Guatemala se opuso a la violación del derecho a la verdad, al considerar que este derecho, no está contenido en la Convención. Al respecto, el Tribunal concluyó que "las alegadas violaciones del derecho a conocer la verdad se enmarcan en el proceso de transición que siguió a la firma de los acuerdos de paz, luego de terminado el conflicto armado y estableció que el Estado, violó el derecho a la integridad personal consagrado en los artículos 5.1 y 5.2 de la Convención Americana, al impedir a los familiares el esclarecimiento de la verdad histórica, a través de la vía extrajudicial establecida por el propio Estado en los acuerdos de paz y la Ley de Reconciliación Nacional. (Corte I.D.H., Caso Diario Militar vs Guatemala, 2012, párr. 295). 
En el año 2012 la Corte se pronuncia nuevamente frente al derecho a la verdad en el caso de las Masacres de El Mozote y lugares aledaños vs El Salvador. En este caso la Corte IDH realiza un amplio análisis frente a la violación al derecho a la verdad de las víctimas, el papel de las comisiones de la verdad y el acceso a la información, el esclarecimiento y el acceso a la justicia de las víctimas.

En este caso, los representantes de las víctimas alegaron que si bien el derecho a la verdad no aparece declarado en el texto de la Convención Americana, se encontraría contenido en las protecciones consagradas en los artículos 1.1, 8, 25, y 13 de la misma. Al respecto, los representantes de las víctimas argumentaron que

[E]n el presente caso el Estado violó el derecho a la verdad de las víctimas y sus familiares en la medida en que las masacres habrían sido cometidas por agentes del Estado, como parte de una estrategia militar. En consecuencia, el Estado sería el único que tiene en sus manos información relevante para establecer la verdad de lo ocurrido (Corte I.D.H., Caso Masacres de El Mozote y lugares aledaños vs El Salvador, 2012, párr. 297).

El Tribunal concluye recordando que, el Estado violó el artículo 13 de la Convención Americana (libertad de pensamiento y de expresión). Igualmente desarrolla el derecho a la verdad a partir de la interpretación de los artículos 1.1, 8.1, 25 de la Convención y establece una estructura argumentativa para la protección al derecho a la verdad bajo la óptica del derecho de acceso a la justicia y el deber de investigar:

Respecto a la alegada violación del artículo 13 de la Convención, la Corte recuerda que toda persona, incluyendo los familiares de las víctimas de graves violaciones a Derechos Humanos, tiene, de acuerdo con los artículos 1.1, 8.1, 25, así como en determinadas circunstancias el artículo 13 de la Convención, el derecho a conocer la verdad, por lo que aquéllos y la sociedad toda, deben ser informados de lo sucedido. Asimismo, la Corte considera pertinente reiterar, como lo ha hecho en otros casos que, en cumplimiento de sus obligaciones de garantizar el derecho a conocer la verdad, los Estados pueden establecer comisiones de la verdad, las que contribuyen a la construcción y preservación de la memoria histórica, el esclarecimiento de hechos 
y la determinación de responsabilidades institucionales, sociales y políticas en determinados períodos históricos de una sociedad. No obstante, esto no completa o sustituye la obligación del Estado de establecer la verdad a través de procesos judiciales, por lo cual era una obligación del Estado iniciar e impulsar investigaciones penales para determinar las correspondientes responsabilidades. En el presente caso, la Corte considera que no procede emitir un pronunciamiento sobre la alegada violación de aquella disposición, sin perjuicio del análisis ya realizado bajo el derecho de acceso a la justicia y la obligación de investigar. (Corte I.D.H., Caso Masacres de El Mozote y lugares aledaños vs El Salvador, 2012, párr. 298).

En el caso Gomes Lund y otros (Guerrilha do Araguaia) vs Brasil (2010), la Corte analiza la responsabilidad del Estado por la detención arbitraria, tortura y desaparición forzada de 70 personas, miembros del Partido Comunista de Brasil y campesinos de la región. El contexto se sitúa en los hechos que siguieron al golpe militar de 1964, a partir del cual se implementó en Brasil la doctrina de la seguridad nacional y la consecuente emisión de variadas normas de seguridad y estados de excepción. Durante 1964 y 1979, se presentaron gran cantidad de violaciones a los Derechos Humanos, el Estado de Brasil decidió implementar una ley de Amnistía, así como variados mecanismos posteriores orientados a generar una transición a la democracia. Entre ellos se implementó la Comisión Especial sobre Muertos y Desaparecidos Políticos.

En este caso, el pronunciamiento de la Corte sobre las medidas legislativas y administrativas que se tomaron en el proceso de paz y reconciliación, trae a colación su jurisprudencia en torno a la prohibición de amnistías, y se pronuncia sobre graves violaciones a los Derechos Humanos que han sido considerados en algunos pronunciamientos de la corte como crímenes de lesa humanidad y crímenes internacionales. En este punto, es importante aclarar que la Corte no es la llamada a juzgar crímenes de lesa humanidad, sin embargo en sus pronunciamientos se pronuncia en torno a los hechos probados que constituyen el contexto y frente a cada uno de los elementos que permitirían establecer que se trata de la comisión de crímenes de lesa humanidad.

La base jurídica sobre la cual la Corte desarrolla el derecho a la verdad en este caso, se relaciona con el derecho a la libertad de pensamiento y expresión (art 13 de la Convención Americana). Al respecto, la Corte concluye que "las medidas legislativas y administrativas sobre restricciones de 
acceso a la información secreta en poder del Estado, han impedido la reconstrucción de los hechos y consecuentemente, de la verdad" (Corte I.D.H., Caso Guerrilha do Araguaia vs Brasil, 2010, párr. 185).

El caso ilustra cómo el acceso a la información constituye una piedra angular del derecho a la verdad, y cómo en contextos de justicia transicional o procesos de paz y reconciliación en sentido amplio, se puede tornar inocua la garantía y efectividad del derecho a la verdad, debido a restricciones frente al acceso a archivos, documentos y demás elementos claves frente al esclarecimiento de hechos pasados. La Corte insiste en la importancia de las comisiones de la verdad como medida de reparación, en perspectiva de satisfacer los derechos de las víctimas, sin embargo es contundente en destacar que "las actividades e informaciones que, eventualmente, recabe dicha comisión no sustituyen la obligación del Estado de establecer la verdad y asegurar la determinación judicial de responsabilidades individuales a través de los procesos judiciales penales" (Corte I.D.H., caso Guerrilha do Araguaia vs Brasil, 2010, párr. 297). Finalmente concluye:

El Estado es responsable por la violación del derecho a la libertad de pensamiento y de expresión consagrado en el artículo 13 de la Convención Americana sobre Derechos Humanos, en relación con los artículos 1.1, 8.1 y 25 de dicho instrumento, por la afectación del derecho a buscar y a recibir información, así como del derecho a conocer la verdad de lo ocurrido (Corte I.D.H., caso Guerrilha do Araguaia vs Brasil, 2010, p.116).

Tanto la Comisión como la Corte Interamericana se aproximaron al derecho a la verdad a partir de las demandas de las víctimas y sus representantes, quienes sustentan la garantía de este derecho a partir de las diferentes fuentes de carácter convencional y de los instrumentos que hacen parte del Derecho Internacional de los Derechos Humanos. Por tanto, su naturaleza e interpretación, está sujeta a debates de tipo jurídico y argumentativo, los cuales varían según el contexto factico sobre el cual se situé el juez interamericano.

De otra parte, tanto la Comisión como la Corte han establecido la intrínseca relación que existe entre democracia y derecho a la verdad. En reiterada jurisprudencia se ha establecido que "la falta de información completa, objetiva y verás, sobre lo sucedido durante esos periodos ha sido una constante, una política de Estado e incluso una estrategia de guerra" (CIDH, 2014, párr. 48), en razón a esto, la Asamblea General de la Organización de los Estados Americanos a través de la resolución 
AG/RES 2175(XXXVI-O/06, ha solicitado reiteradamente a la Comisión Interamericana establecer estándares en materia de derecho a la verdad.

La evolución del derecho internacional, particularmente de conceptos jurídicos como crímenes de lesa humanidad, crímenes de guerra y graves violaciones a los Derechos Humanos, tiene una relación directa con el modo conforme el cual se concibe la naturaleza jurídica del derecho a la verdad. Esta evolución de conceptos tiene una influencia directa respecto a las obligaciones internacionales de los Estados en el marco del Sistema Interamericano de Protección de los Derechos Humanos. A partir del análisis realizado, podemos concluir que el derecho a la verdad adquiere una connotación preponderante, cuando la Corte determina ciertas violaciones a los Derechos Humanos como crímenes de guerra y de lesa humanidad. La imprescriptibilidad de los crímenes de lesa humanidad le imprime la obligación a los Estados de adelantar investigaciones serias frente a dichos crímenes y crea estándares mucho más altos que tratándose de violaciones a los Derechos Humanos, lo cual debe ser tenido en cuenta frente a los mecanismos de justicia transicional que se pretendan implementar en un futuro.

La Comisión ha sostenido que en casos de crímenes de lesa humanidad, crímenes de guerra y/o violaciones a los Derechos Humanos que tienen el carácter de imprescriptibles, como la comisión de asesinatos, desapariciones forzadas, violaciones sexuales, traslados o desplazamiento forzoso, torturas, actos inhumanos destinados a causar la muerte o graves daños a la integridad física y mental, ataques contra la población civil o sus bienes, reclutamiento de niños, niñas y adolescentes, los Estados tienen un deber reforzado de investigación y esclarecimiento de los hechos. Igualmente el esclarecimiento de la verdad de lo sucedido adquiere una relevancia particular cuando los hechos se desarrollan dentro de un conflicto armado de carácter no internacional (CIDH, 2014, párr. 76).

Los estándares desarrollados frente al derecho a la verdad en el marco del Sistema Interamericano evolucionan principalmente en dos vías. En un primer momento, es el resultado de las demandas de las víctimas ante la falta de investigación, información y sanción, por parte de los Estados, principalmente del Cono Sur, donde la práctica de la desaparición forzada hizo parte fundamental de los repertorios de violencia empleados por los regímenes dictatoriales y/o autoritarios a través de sus fuerzas de seguridad. Desde este punto de vista, la Corte Interamericana desarrolló el derecho a la verdad de las víctimas a partir de su vinculación directa y fundamental con la obligación de los Estados de investigar y sancionar a los responsables. En ese sentido, el derecho a la verdad 
se constituye inicialmente como un elemento esencial derivado de los derechos a la protección judicial y las garantías judiciales.

En un segundo momento se realiza la integración de instrumentos de carácter internacional desarrollados en el marco del Sistema de Naciones Unidas, que le imprimen al derecho a la verdad, un carácter autónomo e inalienable.

El derecho a la verdad es una norma de derecho internacional consuetudinario que tiene como una de sus fuentes la jurisprudencia de diferentes órganos internacionales de derechos humanos, es un derecho de carácter autónomo y a partir de los estudios e informes de Orentlicher y Joinet, se convierte en un elemento sustancial para la lucha contra la impunidad, así como un pilar fundamental de la justicia y la reparación frente a violaciones sistemáticas a los derechos humanos.

De esta manera podríamos decir, que si en un primer momento el derecho a la verdad es vinculado con las obligaciones internacionales de los Estados en virtud de las normas y derechos establecidos en la Convención Americana, en un segundo momento su desarrollo está íntimamente ligado con el derecho a la reparación por graves violaciones a los Derechos Humanos, crímenes de lesa humanidad y violaciones al DIH, base jurídica que se encuentra establecida en dos instrumentos fundamentalmente: I) Conjunto de Principios actualizado para la protección y promoción de los Derechos Humanos mediante la lucha contra la impunidad y II) Los Principios y directrices básicos sobre el derecho de las víctimas de violaciones manifiestas de las normas internacionales de Derechos Humanos y de violaciones graves de Derechos Humanos y de violaciones graves del Derecho Internacional Humanitario a interponer recursos y obtener reparaciones.

Podríamos agregar un tercer elemento o momento frente al desarrollo y la naturaleza jurídica del derecho a la verdad en el marco del Sistema Interamericano, esto es, su vinculación con el respeto de los Derechos Humanos y la reparación integral a las víctimas en contextos de justicia transicional, procesos de paz y de reconciliación y su consecuente vinculación en esta misma perspectiva con otros derechos como el acceso a la información, la libertad de pensamiento y expresión, el acceso a la justicia, la integridad personal y la obligación de investigar, esclarecer y sancionar a los responsables de graves violaciones a los derechos humanos.

En punto a la relación entre derecho a la verdad y justicia transicional, la Comisión ha manifestado que: "En contextos transicionales, los derechos a la libertad de expresión y al acceso a 
la información adquieren una importancia estructural" (Corte I.D.H., Caso Diario Militar vs. Guatemala 2012, párr. 473).

Por último, el derecho al verdad, en la actualidad es un elemento central del deber de memoria, o deber de recordar de los Estados, está ligado con la gran variedad de mecanismos que en perspectiva de justicia transicional se utilizan para reconstruir la verdad, proteger archivos, acceder a la información, reparar a las víctimas, hacer memoria histórica sobre los hechos del pasado y consolidar un Estado bajo los principios de la democracia. "El derecho a ser informado sobre lo sucedido y de acceder a la información también incluye a la sociedad en general en tanto resulta esencial para el desarrollo de sistemas democráticos" (CIDH, 1999. párr. 224).

\subsubsection{El Derecho a la verdad como medida de reparación.}

La Corte Interamericana a través de su jurisprudencia ha establecido en diversas ocasiones que

Las víctimas de violaciones de Derechos Humanos tienen derecho a la reparación adecuada del daño sufrido, la cual debe concretizarse mediante medidas individuales tendientes a restituir, indemnizar y rehabilitar a la víctima, así como medidas de satisfacción de alcance general y garantías de no repetición" (CIDH, 2008. párr. 1).

En consecuencia, el derecho a la verdad forma parte integral de la reparación por violaciones a los Derechos Humanos y constituye la principal medida de satisfacción y garantía de no repetición de las violaciones.

En lo que respecta al derecho a la verdad como medida de reparación, la Corte Interamericana ha establecido respecto a casos concretos la necesidad de iniciar, impulsar, reabrir, dirigir, continuar y concluir con la mayor diligencia posible, las investigaciones y procesos pertinentes, teniendo en cuenta desde luego, el denominado plazo razonable. Estas medidas tienen el objeto de "establecer toda la verdad de los hechos y determinar las responsabilidades penales que pudieran existir, y remover todos los obstáculos de facto y de jure que mantienen la impunidad total" (CIDH, 2014, p.59).

La prohibición de recurrir a la apertura de procesos de amnistía en beneficio de autores de graves violaciones a los Derechos Humanos, así como de figuras análogas como la prescripción, irretroactividad de la ley penal, cosa juzgada, o cualquier otro eximente de responsabilidad para 
excusarse de la obligación, hace parte integral de las medidas de reparación que se establecen frente a determinados casos donde se ha solicitado a la Corte hacer responsable al Estado por la violación al derecho a la verdad.

Dentro del amplio catálogo de medidas orientadas a garantizar el derecho a la verdad de las víctimas se cuentan entre otras, I) el deber de establecer el patrón sistemático de violaciones a Derechos Humanos; II) establecer el contexto en el cual se presentaron las violaciones; III) identificación e individualización de todos los autores materiales e intelectuales; IV) la obligación de todas las autoridades estatales de colaborar en la recaudación de la prueba; V) el deber de mantener todas las investigaciones sobre graves violaciones de los Derechos Humanos en la jurisdicción ordinaria; VI) publicación de los resultados de las investigaciones; VII) deber de garantizar el acceso de toda la sociedad e instituciones y organizaciones a los archivos sobre violaciones graves de los Derechos Humanos; y VIII) promover acciones pertinentes de cooperación internacional con otros Estados, a fin de facilitar la recopilación y el intercambio de información, así como otras acciones legales que correspondan. (CIDH 2014, P. 59 -61).

Frente al derecho a la verdad como medida de reparación en perspectiva de satisfacción en su dimensión colectiva, la $\mathrm{CIDH}$ ha establecido que "el derecho de una sociedad a conocer íntegramente su pasado no sólo se erige como un modo de reparación y esclarecimiento de los hechos ocurridos, sino que tiene el objeto de prevenir futuras violaciones" (CIDH, 2000, párr. 148).

Finalmente, la Corte establece cuatro elementos estructurales que componen la integralidad en relación con la construcción de la verdad como medida de satisfacción en su dimensión colectiva, esto es: I) la obligación de investigar las graves violaciones a los Derechos Humanos; II) la divulgación pública de los resultados; III) la determinación judicial de los patrones de actuación conjunta; y IV) la determinación de todas las personas que de diversas formas participaron en las violaciones y sus correspondientes responsabilidades. (CIDH 2014 P. 37 - 38)

Como forma de sintetizar concluir lo desarrollado en este aparte vale decir que el derecho a la verdad, en el contexto del Sistema Regional de Protección de los Derechos Humanos, es un elemento esencial del derecho a la justicia, y constituye una obligación de los Estados en perspectiva del cumplimiento de las garantías establecidas en los artículos 8 y 25 de la Convención Americana. Igualmente el derecho a la verdad tiene un fundamento moral, ético y político que se desprende de las 
acciones en contra de la impunidad y por tanto se constituye como requisito para el desarrollo del sistema democrático del Estado.

Para finalizar este aparte, es importante resaltar que la importancia del derecho a la verdad y su progresiva evolución en el contexto del Sistema Interamericano de Protección de los Derechos Humanos, esta vinculada con el desarrollo de los derechos a la protección y garantías judiciales. La lucha contra la impunidad, la cual entiende la Corte como la falta en su conjunto de investigación, persecución, captura, enjuiciamiento y condena de los responsables de las violaciones de los derechos protegidos por la Convención Americana, ha producido una ampliación del derecho a la verdad y progresivamente una importancia estructural frente a casos donde se pretende procesar crímenes de lesa humanidad, crímenes de guerra y/o violaciones a los Derechos Humanos que tienen el carácter de imprescriptibles y por tanto existe una obligación internacional de los Estados en cuanto a un deber reforzado de investigar y esclarecer los hechos.

En un mismo sentido, "el esclarecimiento de la verdad de lo sucedido adquiere una relevancia particular cuando los hechos se desarrollan dentro de un conflicto armado no internacional" (Corte I.D.H., Caso Diario Militar vs. Guatemala 2012, subrayado fuera del texto).

Para los órganos del Sistema, es claro, que el derecho a conocer la verdad sobre lo sucedido no se limita a las víctimas y sus familiares, sino también a la sociedad en su conjunto. Según la Corte, esto se satisface a partir del cumplimiento de la obligación del Estado de investigar de oficio las graves violaciones a los Derechos Humanos y, por el otro, con la divulgación pública de los resultados de los procesos penales e investigativos.

La Corte ha establecido que la satisfacción del derecho a la verdad exige la determinación procesal de la más completa verdad histórica posible._Para los órganos del Sistema, esta verdad histórica incluye tres elementos: I) determinación judicial de los patrones de actuación conjunta, II) determinación de todas las personas que de diversas formas participaron en dichas violaciones, y III) determinación de responsabilidades ${ }^{19}$.

\footnotetext{
${ }^{19}$ Sentencias sistematizadas para comprender este punto: Corte IDH. Caso de la Masacre de la Rochela Vs. Colombia. Fondo, Reparaciones y Costas. Sentencia de 11 de mayo de 2007. Serie C No 163, párr. 195; Caso Ibsen Cárdenas e Ibsen Peña Vs. Bolivia. Fondo, Reparaciones y Costas. Sentencia de 1 de septiembre de 2010 Serie C Nº 217, párr. 158; Caso Chitay Nech y otros Vs. Guatemala. Excepciones Preliminares, Fondo, Reparaciones y Costas. Sentencia de 25 de mayo de 2010. Serie C No212, párr. 234; Caso Gelman Vs. Uruguay. Fondo y Reparaciones. Sentencia de 24 de febrero
} 
Por ultimo cuando estamos frente a contextos de justicia transicional, la Comisión ha reconocido la complejidad frente a la garantía de este derecho en el contexto de estos escenarios, por tanto su análisis se debe remitir a los parámetros que se encuentran en el siguiente marco normativo: I) Conjunto de principios actualizado para la protección y la promoción de los Derechos Humanos mediante la lucha contra la impunidad (Conjunto de principios, 8 feb. 2005), II) los principios y directrices básicos sobre el derecho de las víctimas de violaciones manifiestas de las normas internacionales de Derechos Humanos y de violaciones graves del Derecho Internacional Humanitario a interponer recursos y obtener reparaciones (Resolución No. 60/147, 16 dic. 2005); III) Resolución No. 12/11 y Resolución No. 12/12 del Consejo de Derechos Humanos sobre Derechos Humanos y justicia de transición y derecho a la verdad, 1 oct. 2009.

\section{Conclusiones}

El derecho a la verdad, emerge desde la necesidad de las víctimas y sus familiares de conocer la verdad de los hechos acaecidos en el marco de graves infracciones a los derechos humanos, más concretamente en contextos dictatoriales o de guerra y en relación al delito de desaparición forzada, como principal antecedente.

No obstante lo anterior, el derecho de las víctimas a saber, ha venido ampliando su contexto de aplicación, y tiene hoy por hoy, un alcance que permite a las víctimas conocer las circunstancias en que graves violaciones a derechos humanos fueron perpetradas pero además, permite indagar sobre los responsables de estas violaciones y los contextos en los que las mismas fueron llevadas a cabo.

En esta condiciones, el derecho a la verdad se presenta en conexidad con otros derechos como acceso a la información, desclasificación de documentos, integridad personal y libertad de expresión y de pensamiento, sin embargo, el derecho a conocer la verdad sobre lo ocurrido cobra especial importancia en relación con la lucha contra la impunidad y en consecuencia con el acceso a la justicia, la cual es administrada por el Estado. Este, está obligado a aportar recursos e información

de 2011 Serie C № 221, párr. 192., Tomado de. El Derecho a la Verdad en las Américas, Comisión Interamericana de Derechos Humanos, pág. 38. 
para contribuir con el esclarecimiento de los hechos como elemento fundamental para garantizar la no repetición de estos crímenes.

En relación con la justicia el derecho a la verdad tiene un alcance reparador. La verdad, como elemento que permite dignificar a las víctimas y garantiza la no impunidad, permite no solo la no repetición de los hechos sino que además restablece los derechos de quienes han sido afectados y les da la posibilidad de conocer a los responsables.

El derecho a la verdad evolucionó hasta convertirse en una norma de derecho internacional consuetudinaria de carácter imperativo, con diversas fuentes entre las cuales se encuentra la jurisprudencia de los órganos internacionales.

La verdad como derecho tiene una dimensión individual y colectiva, los sujetos activos son las víctimas de graves violaciones a los derechos humanos, crímenes de lesa humanidad e infracciones al derecho internacional humanitario, los Estados tienen el deber de garantizar el derecho a la verdad implementando diversos mecanismos e instrumentos que permitan su realización efectiva.

El surgimiento y evolución de la justicia transicional ha influido directamente en la estructuración del derecho a la verdad. En contextos de justicia transicional el derecho a la verdad adquiere una importancia central, dado que su dimensión colectiva emerge convirtiéndose en un derecho de toda la sociedad que se concreta en el deber de recordar y en los diferentes mecanismos para la construcción de memoria histórica como patrimonio histórico de los pueblos.

Los mecanismos implementados para la realización efectiva del derecho a la verdad deben permitir el esclarecimiento de los hechos y el acceso a la información. Los instrumentos para garantizar el desarrollo efectivo del derecho a la verdad deben contener medidas orientadas al esclarecimiento de los hechos, esto es: I) el deber de establecer el patrón sistemático de violaciones a Derechos Humanos; II) establecer el contexto en el cual se presentaron las violaciones; III) identificación e individualización de todos los autores materiales e intelectuales; IV) la obligación de todas las autoridades estatales de colaborar en la recaudación de la prueba; $V$ ) el deber de mantener todas las investigaciones sobre graves violaciones de los Derechos Humanos en la jurisdicción ordinaria; VI) publicación de los resultados de las investigaciones; VII) deber de garantizar el acceso de toda la sociedad e instituciones y organizaciones a los archivos sobre violaciones graves de los Derechos Humanos; y VIII) promover acciones pertinentes de cooperación internacional con otros Estados, a fin 
de facilitar la recopilación y el intercambio de información, así como otras acciones legales que correspondan. (CIDH 2014, P. 59 -61)

La garantía y efectividad del derecho a la verdad reposa en gran medida en la posibilidad de responder a los mecanismos antes mencionados de una manera integral, interdependiente y armónica que permita avanzar en la comprensión y trámite ético de los diferentes mecanismos de violencia que atacan a la humanidad en su conjunto.

El desarrollo del derecho penal internacional a partir del fin de la segunda guerra mundial ha influido de forma directa en el desarrollo de la naturaleza jurídica del derecho a la verdad, hoy en día existe una conciencia humanitaria internacional sujeto activo abstracto que le imprime una preponderancia particular a la garantía y efectividad de las medidas orientadas a la realización del derecho a la verdad en su dimensión colectiva, cuyos objetivos incluyen el derecho de la sociedad a conocer y comprender y dar trámite a su pasado. 


\section{EL DERECHO A LA VERDAD EN CONTEXTOS DE JUSTICIA TRANSICIONAL}

No se puede entender la naturaleza jurídica del derecho a la verdad sin abordar su relación con la justicia transicional. Este hecho en el contexto Latinoamericano, está relacionado con la violencia ejercida por los Estados autoritarios, por los gobiernos dictatoriales y en algunos casos, por su evolución hacia convulsiones políticas límites y conflictos armados de carácter interno. Se trata de la adopción de instrumentos de justicia, cuyo propósito consiste en facilitar procesos de rendición de cuentas que permitan el tránsito de la guerra a la paz o de la dictadura a la democracia. En palabras del Relator Especial para el fomento de la verdad, la justicia y la reparación de Naciones Unidas, "es una estrategia para lograr que la justicia corrija violaciones masivas de Derechos Humanos en tiempos de transición" (La Justicia Transicional, 11/09/2012) ${ }^{20}$.

La verdad, desde este punto de vista, es considerada un requisito ético político cuya fundamentación hace parte de la evolución del derecho internacional y del discurso de los Derechos Humanos. Desde el punto de vista social e histórico, puede ser considerado como producto de un proceso caracterizado por la emergencia de la prevalencia de la mirada al pasado, como elemento fundamental para la configuración del futuro ${ }^{21}$ y por tanto, como elemento sustancial de los procesos de reconstrucción de memoria colectiva, garantizando así la no repetición (Orenticher, 2004,). Igualmente puede ser entendido como producto de la crisis del punitivismo penal, es decir de los límites del derecho penal para abordar procesos masivos de violencia estructural22.

\footnotetext{
20 Véase, asimismo, ONU, Consejo de Derechos Humanos, $21^{\circ}$ sesión, Informe del Relator Especial para la promoción de la verdad, justicia, reparación y garantías de no repetición, Pablo de Greiff, A/HRC/21/46, 9 de agosto de 2012.

21 Frente a la nueva prevalencia de las razones que miran al pasado, Iván Orozco Abad, en su libro "Justicia transicional en tiempos del deber de memoria" ilustra de manera clara, la llamada crítica memoriosa a la modernidad, "la crítica de la mirada de futuro con sus mañanas utópicos, con su volverle la espalda al pasado, a un pasado que constriñe la libertad para configurar el presente y el futuro, y con su disposición a voltear la página para olvidar. Ahora se trata de recordar y de castigar para no repetir. Ahora se trata de que el pasado oriente el futuro" Orozco (2009, P.57)

${ }^{22}$ Resalto aquí el ejemplo de el Salvador, en donde la implementación de una comisión de la verdad, surgió como forma de contrarrestar la amnistía decretada por el régimen saliente y como forma de luchar contra la impunidad (Hayner, 2002, p.47).
} 
En contextos de justicia transicional, la búsqueda de la verdad se da necesariamente en el marco de la búsqueda de la justicia. Desde el punto de vista de los gobiernos, es aquí donde radica su conflictividad. La realidad latinoamericana es determinante en este sentido, ya que ante la presión interna e internacional, los gobiernos se muestran dispuestos a admitir que se busque la verdad de lo ocurrido. Sin embargo, pocas veces aceptan las consecuencias de la verdad encontrada. Ante las demandas de justicia, "se encuentran mil pretextos para evitar que los culpables aparezcan ante la justicia, y si no se puede evitar, no faltan los mecanismos para que salgan impunes" (Huhle, 2005, p. 28). Pese a lo anterior, la Corte IDH, ha manifestado reiteradamente que en el marco de la justicia transicional, la creación de un sistema de incentivos útiles a la verdad contribuye indefectiblemente al establecimiento de una paz duradera, en estos contextos el derecho de acceso a la información adquiere una importancia central (CIDH, 2014, párr. 85, 129).

Quizás esta conflictividad o tensión, que se genera al momento de implementar mecanismos de justicia transicional y búsqueda de la verdad, tenga que ver con el contenido altamente político que tienen estos mecanismos, frente a lo cual surgen las tensiones históricas y las complejidades de las relaciones entre la política y el derecho. La justicia transicional desde esta perspectiva puede ser vista como un campo de batalla para las razones que miran hacia adelante y las razones que miran hacia atrás, en el centro de esta tensión se encuentra el derecho a la verdad.

Las comisiones de la verdad, como órganos oficiales, temporales, extrajudiciales y de constatación de hechos, se erigen como el instrumento más importante para la búsqueda de la verdad en contextos de justicia transicional: son "la fórmula mágica" de los gobiernos ${ }^{23}$ ante la necesidad de

\footnotetext{
${ }^{23}$ En la región, se han implementado numerosas Comisiones de la Verdad, a saber: (i) la Comisión Nacional sobre la Desaparición de Personas de Argentina (1983); (ii) la Comisión Nacional de Investigación de Desaparecidos Forzados de Bolivia (1982); (iii) la Comisión Especial sobre Muertos y Desaparecidos Políticos (1995), la Comisión de Amnistía del Ministerio de Justicia (2001) y la Comisión Nacional de la Verdad (2011) de Brasil; (iv) la Comisión Nacional de Verdad y Reconciliación (1990) y la Comisión Nacional sobre Prisión Política y Tortura (2003) de Chile; (v) la Comisión Nacional de Reparación y Reconciliación (2005) y el Centro de Memoria Histórica (2011) de Colombia; (vi) la Comisión Verdad y Justicia (1996) y la Comisión de la Verdad (2007) de Ecuador; (vii) la Comisión de la Verdad (1992) de El Salvador; (viii) la Comisión de la Verdad y la Reconciliación (2001) de Granada; (ix) la Comisión para el Esclarecimiento Histórico de las Violaciones a los Derechos Humanos y los Hechos de Violencia que han Causado Sufrimientos a la Población Guatemalteca (1997) de Guatemala; (x) la Comisión Nacional de la Verdad y la Justicia (1995) de Haití; (xi) la Comisión de la Verdad y la Reconciliación (2009) de Honduras; (xii) la Comisión de la Verdad (2001) de Panamá; (xiii) la Comisión de la Verdad y la Justicia ( 2003) de Paraguay; (xiv) la Comisión de la Verdad y Reconciliación (2000) de Perú; y (xv) la Comisión Investigadora Parlamentaria sobre la Situación de Personas Desaparecidas y Hechos que la Motivaron (1985) y la Comisión para la Paz (2000) de Uruguay. Asimismo, en el año 2008 Canadá creó una Comisión de la Verdad y
} 
separar verdad y justicia. Al respecto, la CIDH se ha manifestado reiteradamente, estableciendo que "no sustituyen la obligación indelegable del Estado de investigar las violaciones que se hayan cometido dentro del ámbito de su jurisdicción, de identificar a los responsables, de imponerles sanciones y de asegurar a la víctima una adecuada reparación" (CIDH, 2014, párr. 133). En este sentido, el mensaje es claro a los gobiernos: la creación de una comisión de la verdad no puede estar basada en "la premisa de que no habrá juicios, sino en que constituye un paso en el sentido de la restauración de la verdad, y oportunamente, de la justicia" (CIDH, 2014, párr. 133).

Frente a la problemática de las relaciones entre la búsqueda de la verdad y la consecución de la justicia, vale la pena recordar lo establecido en el famoso ensayo escrito por Rainer Huhle ${ }^{24}$, con ocasión del 50 aniversario del Tribunal de Nuremberg, en el cual se reconoce, frente al mecanismo de la comisión de la verdad, que en los casos en los cuales se ha implementado bien, se ha producido un momento de rehabilitación moral y público para las víctimas. Sin embargo, Huhle afirma "si la verdad queda establecida, y si esta verdad es una verdad terrible, una verdad de crímenes atroces, de culpas enormes, la falta de justicia queda aún más visible y más sentida. Si la verdad es solo para la historia hace sentir aún más el dolor de la injusticia" (Huhle 2005, p. 38).

En el contexto de una comisión de la verdad, el derecho a la verdad se sintetiza en la garantía de los derechos a la libertad de expresión y acceso a la información, de donde derivan obligaciones para los Estados frente al contenido de la información que se construya a través del mecanismo. El contenido mínimo del derecho a la verdad se debe ver reflejado en la información que arroje la comisión, la cual debe comprender: I) la conducta de quienes se hayan involucrado en la comisión de violaciones graves a los Derechos Humanos o al DIH, especialmente en casos de masividad y sistematicidad; II) los elementos de carácter objetivo y subjetivo que contribuyeron a crear las condiciones y circunstancias dentro de las cuales fueron perpetradas conductas atroces, así como la identificación de factores de índole normativa y fáctica que dieron lugar a la aparición y el mantenimiento de situaciones de impunidad; III) los elementos para establecer si los mecanismos estatales sirvieron de marco a la consumación de conductas punibles; IV) la identificación de las víctimas y sus grupos de pertenencia así como a quienes hayan participado de actos de victimización

Reconciliación con un mandato específico de investigaciones violaciones de derechos en el contexto del tratamiento de niños indígenas en escuelas residenciales.

${ }^{24}$ Director del Centro de Estudios de Derechos Humanos de Nuremberg. 
y por último, V) los elementos que permitan la comprensión del impacto de la impunidad (CIDH, 2004, párr. 32).

La jurisprudencia de la Corte IDH, ha venido estableciendo criterios frente a la garantía del derecho a la verdad en el marco de la implementación de mecanismos de justicia transicional y de búsqueda de la verdad. En el marco de su jurisdicción, la Corte fue estableciendo criterios frente a las leyes de amnistía y auto amnistía, el caso emblemático en este sentido es el caso Barrios Altos vs Perú, donde quedó establecido que las disposiciones de amnistía son inadmisibles por contradecir derechos inderogables reconocidos por el Derecho Internacional de los Derechos Humanos (Corte I.D.H, caso Barrios Altos vs Perú, 2001, párr.41)

Esta línea jurisprudencial se mantuvo en varios casos posteriores ${ }^{25}$, e inclusive se fue profundizando en algunos aspectos hasta conformar una línea jurisprudencial clara en relación con las disposiciones de amnistía. Sin embargo, a partir del conocimiento sobre el caso de El Mozote y lugares aledaños vs el Salvador, se conformaron nuevos criterios, en razón a que fue el primer caso donde la Corte tuvo que pronunciarse sobre una disposición de amnistía, en el contexto de un proceso orientado a poner término por la vía negociada a un conflicto armado de carácter no internacional. En esta sentencia se estableció:

El presente caso de amnistía deriva de un contexto distinto a todos los anteriores, ello tiene repercusiones frente al análisis y calificación jurídica de los hechos y en los conceptos y consideraciones de la Corte (...) es por ello, que en el razonamiento de la Corte, se ha tenido que tomar en cuenta no solo las normas y principios de Derecho Internacional de los Derechos Humanos sino las disposiciones pertinentes del Derecho Internacional Humanitario dado el contexto dentro del cual se produjeron los hechos. (Corte I.D.H., Caso Masacres de Mozotes y lugares aledaños vs. El Salvador 2012, párr. 10).

El aporte central de esta sentencia es el reconocimiento por parte de la Corte de que en ciertos contextos, como los procesos de negociación y terminación de un conflicto armado y por tanto en el marco de procesos justicia transicional, las amnistías pueden "ser permitidas como componente de la

${ }^{25}$ Almohacid Arellano y otros vs Chile (2006), La Cantuta respecto de Perú (2006), Gómez Lund vs Brasil (2010). 
finalización de un conflicto armado no internacional" (Corte I.D.H., Caso Masacres de Mozotes y lugares aledaños vs. El Salvador 2012, párr.17), sin embargo tienen un límite que está constituido por los crímenes de guerra y los crímenes de lesa humanidad, aspectos ambos, que no son susceptibles de olvido e impunidad. En estos casos el derecho a la verdad constituye una piedra angular, pues está de nuevo muy en sintonía con su concepción más dura, entendida como el derecho a conocer 0 derecho a saber las circunstancias y el contexto en el caso específico.

En virtud de lo anterior podemos concluir, que cuando se trata de contextos de justicia transicional desarrollados en el marco de procesos de negociación, que pretenden poner fin a un periodo de conflicto armado de carácter no internacional, las disposiciones de amnistía están permitidas frente a violaciones a los Derechos Humanos que no constituyan crímenes de lesa humanidad o crímenes de guerra. Lo anterior teniendo como base jurídica la aplicación del Protocolo Adicional II de las Convenciones de Ginebra, en las cuales se precisa que "el objeto de las amnistías es alentar un gesto de reconciliación que contribuya a restablecer el curso normal de la vida de un pueblo que ha estado dividido"26.

A partir de esta sentencia la Corte IDH reconoce que en el marco de conflictos armados de carácter no internacional existe una gran complejidad debido a la presencia de múltiples niveles de victimización que corresponden además a una multiplicidad de victimarios y por tanto la aplicación de amnistías puede contribuir a una gran variedad de escenarios que plantean

Un abanico de posibles resultados que pueden fijar los márgenes para el ejercicio de la ponderación de los intereses en el propósito de conjugar los propósitos de investigación, sanción y reparación de graves violaciones a los Derechos Humanos, de un lado, con los de reconciliación nacional y salida negociada de un conflicto armando no internacional por el otro.

En todo caso frente a estos dilemas que son connaturales a un contexto de justicia transicional no hay solución universalmente aplicable, sin embargo si existen lineamientos que se deben tener en cuenta.

${ }^{26}$ El artículo 6.5 del Protocolo II, se establece que "las autoridades en el poder procurarán conceder la amnistía más amplia posible a las personas que hayan tomado parte en el conflicto armado o que se encuentren privadas de libertad, internadas o detenidas por motivos relacionados con el conflicto armado". 
En punto al derecho a la verdad en virtud de estos escenarios, y en perspectiva de implementar mecanismos de búsqueda de la verdad, como una comisión de la verdad, es necesario otorgar un especial procesamiento prioritario y específico a hechos calificables como crímenes de guerra o crímenes de lesa humanidad que sea diferente al trato otorgado a violaciones de Derechos Humanos.

En todo caso el derecho de las víctimas y de la sociedad de acceder a la verdad en el marco de procesos de negociación y presencia de un conflicto armado de carácter no internacional, debe tener un trato especial en contexto de justicia transicional, que tenga en cuenta el ejercicio de la ponderación, para "delinear las especificidades de la justica de tal forma que no sea antagónica con la justicia transicional requerida en procesos de pacificación y reconciliación" Corte I.D.H., Caso Masacres de Mozotes y lugares aledaños vs. El Salvador 2012, párr.20). Para cumplir con este objetivo es recomendable diseñar mecanismos para un trato diferenciado frente al tratamiento de responsables de las más graves violaciones a los Derechos Humanos, con lo cual se sugiere, fortalecer instrumentos como los de selección y priorización de casos, e igualmente crear instrumentos para abordar casos de menor gravedad.

El derecho a la verdad juega un papel fundamental en contextos de justicia transicional, ya que está en el medio de las tensiones entre el deber de hacer justicia, combatir la impunidad y los anhelos de paz, reconciliación y salida negociada al conflicto. Las comisiones de la verdad son mecanismos que contribuyen a gestionar las dificultades inherentes que se presentan al interior de estos contextos, sin embargo no son los únicos mecanismos a utilizar, existe una gran variedad de mecanismos que pueden entrar a jugar un papel importante para la búsqueda de la verdad. El tema referente al trato de archivos, de instituciones de construcción de la memoria histórica, así como otros mecanismos institucionales para el esclarecimiento de los hechos deben ser tenidos en cuenta por parte de los Estados, más atendiendo a que ya existe un gran cumulo de experiencias a nivel mundial sobre las cuales es bueno reflexionar. La comisión de la verdad, aunque útil, no puede ser el mecanismo central en virtud de un proceso de justicia transicional, ni se puede concentrar el debate y la mirada únicamente en esto como fórmula mágica, el verdadero y más claro horizonte debe ser una política integral de verdad y memoria que facilite las oportunidades de coordinación e intercambio de experiencias y saberes, permita la complementariedad de procesos de producción de verdad y memoria y la maximización del impacto y los recursos. 


\subsection{Estándares}

Uno de los criterios que se han establecido en el contexto del Sistema Interamericano de Protección de los Derechos Humanos tiene que ver con la observancia de estándares frente a contextos de justicia transicional. En este sentido tanto la Corte como la Comisión, reconociendo la complejidad de estos escenarios y la importancia de garantizar los derechos a la verdad, la justicia y la reparación de las víctimas, han estipulado que los parámetros sobre los cuales se deben desarrollar los distintos instrumentos de justicia transicional, deben atender el marco normativo compuesto por el "Conjunto de Principios actualizado para la Protección y la Promoción de los Derechos Humanos mediante la Lucha contra la Impunidad" (Conjunto de principios, 8 feb. 2005), los principios y directrices básicos sobre el derecho de las víctimas de violaciones manifiestas de las normas internacionales de Derechos Humanos y de violaciones graves del DIH a interponer recursos y obtener reparaciones (Resolución N 60/147, 16 dic. 2005) y las Resoluciones 12/11 y 12/12 del Consejo de Derechos Humanos sobre Derechos Humanos, justicia de transición y derecho a la verdad.

\subsubsection{Derecho Internacional Humanitario}

Los estándares que se deben tener en cuenta en relación con el derecho a la verdad de las víctimas de graves violaciones a los Derechos Humanos desde la óptica del Derecho Internacional de los Derechos Humanos, están orientados a la protección de todas las personas contra las desapariciones forzadas, en este sentido el proyecto de la convención Internacional para la Protección de todas las personas contra las desapariciones forzadas establece el derecho que tienen todas las victimas a conocer la verdad sobre las circunstancias de la desaparición forzada, los progresos y resultados de la investigación y la suerte de las personas desaparecidas (art. 24(2) E/CN.4/2005/WG.22/WP.1/REV.4).

En este mismo sentido la declaración de la ONU sobre la protección de todas las personas contra las desapariciones forzadas ${ }^{27}$, se refiere a la obligación internacional frente a la comunicación sobre los resultados de la investigaciones, así como el derecho a un recurso judicial rápido y eficaz, como medio para determinar el paradero de las personas privadas de la libertad y su estado de salud,

\footnotetext{
${ }_{27}$ Adoptada mediante la resolución N 47/133 de la Asamblea General de la ONU de 18 de diciembre de 1992.
} 
así como a la "obligación de informar sobre la autoridad que ordenó la privación de la libertad o la hizo efectiva, esta obligación se establece como medio para prevenir la desaparición forzada en toda circunstancia" (art. 9, resolución N 47/133, 18 dic. 1992).

En punto a las ejecuciones extrajudiciales, arbitrarias o sumarias, el Consejo Económico y Social de la ONU estableció dentro de los principios (resolución № 1989/65, 24 mayo 1989) relativos a una eficaz prevención e investigación el derecho que tienen los familiares de la persona fallecida y sus representantes legales a ser informados sobre las audiencias que se celebren, sobre las cuales se estipula el derecho al acceso, así como el derecho de acceso a la información pertinente a la investigación.

En el año 2000 la Asamblea General de la ONU mediante la resolución N 55/89, elaboró un conjunto de principios relativos a la investigación y documentación eficaces de la tortura y otros tratos o penas crueles, inhumanos o degradantes ${ }^{28}$. En el principio 4 estableció que las presuntas víctimas de torturas o malos tratos y sus representantes legales serán informados de las audiencias que se celebren, a las que tendrán acceso, así como a toda la información pertinente a la investigación.

Frente al delito de desplazamiento forzado de personas, los principios rectores de los desplazamientos internos (E/CN.4/1998/53/Add.2, 11 feb. 1998), en el principio 16, se refieren al derecho que tienen los familiares y desplazados de conocer el destino y el paradero de sus familiares desaparecidos e impone la obligación a las autoridades de averiguar el destino y el paradero de todos los desplazados internos desaparecidos, así como facilitar la cooperación con organizaciones de carácter internacional dedicadas a esta labor, de igual forma establece la obligación de informar a los parientes más próximos sobre la marcha de las investigaciones y la notificación de resultados.

Estos documentos otorgan herramientas claves para garantizar el derecho a la verdad de las víctimas de graves violaciones a los Derechos Humanos tanto en contextos de conflicto armado de carácter internacional como de carácter interno.

${ }^{28}$ Adoptados por la Asamblea General de la ONU, mediante Resolución Nº 55/89 de 4 de diciembre de 2000. (Anexo) 


\subsubsection{Principios y directrices básicos sobre el derecho de las víctimas de violaciones} manifiestas de las normas internacionales de Derechos Humanos y de violaciones graves del Derecho Internacional Humanitario a interponer recursos y obtener reparaciones ${ }^{29}$

Este documento consagra un conjunto de mecanismos, procedimientos, modalidades y métodos para garantizar el cumplimiento de las obligaciones jurídicas establecidas en las normas internacionales que reconocen la protección y garantía de los Derechos Humanos. Se elaboró con el fin de dar las directrices a los Estados para la implementación de las diferentes normas de protección de los Derechos Humanos y sobre todo de protección y garantía de los derechos de las víctimas de graves violaciones a los Derechos Humanos a acceder a la justicia y obtener una reparación pronta y eficaz.

El instrumento contiene de manera detallada las obligaciones de respetar y asegurar que se respeten las normas internacionales de Derechos Humanos y DIH. Establece la fuente de las obligaciones de los Estados frente a las normas internacionales a partir de tres elementos: I) Los tratados en los que un Estado sea parte, II) El derecho internacional consuetudinario y III) El derecho interno de cada Estado.

El instrumento ha servido como eje orientador a la Corte Constitucional Colombiana para desarrollar toda la línea jurisprudencial sobre los derechos de las víctimas del conflicto armado colombiano ${ }^{30}$. De otra parte, resulta importante por cuanto es el primer documento que establece explícitamente como una de las formas de reparación las denominadas medidas de satisfacción, las cuales fueron incorporadas vía bloque de constitucionalidad tanto a la jurisprudencia, como a la Ley 1448 de 2011 o Ley de Víctimas y Restitución de Tierras, particularmente en el capítulo IX donde además el legislador colombiano decidió incluir las medidas tanto de carácter simbólico como todo lo concerniente al deber de memoria del Estado y a la reconstrucción de la memoria histórica.

\footnotetext{
${ }^{29}$ Resolución N 60/147 de 16 de diciembre de 2005 de la Asamblea General de la ONU.

30 En relación con este tema ver especialmente, entre muchas otras, las sentencias T-025 de 2004, C-228 de 2008 (Ms. Ps. Eduardo Montealegre Lynnet y Manuel José Cepeda Espinosa); C-370 de 2006 (Ms. Ps. Cepeda Espinosa, Córdoba Triviño, Escobar Gil, Monroy Cabra, Tafur Galvis y Vargas Hernández); C-454 de 2006 (M. P. Jaime Córdoba Triviño); C1199 de 2008 y C-771 de 2011 (en ambas M. P. Nilson Pinilla Pinilla); C-936 de 2010 (M. P. Luis Ernesto Vargas Silva).
} 
El documento incluye la definición sobre víctima de violaciones manifiestas de las normas internacionales de Derechos Humanos y de violaciones graves del Derecho Internacional Humanitario, el tratamiento que se les debe otorgar, su derecho a interponer recursos y el acceso a la justicia, y desarrolla un importante aparte sobre la reparación de los daños sufridos y el acceso a la información sobre las violaciones y mecanismos de reparación. También contiene un aparte orientado a la reparación de los daños, desarrolla el núcleo esencial de la reparación integral, verdad, justicia y reparación, con las correspondientes medidas de restitución, indemnización, satisfacción y garantías de no repetición de las violaciones.

Estos principios contienen el estándar internacional frente a la forma como deben proceder los Estados cuando se pretende afrontar un contexto caracterizado por violaciones masivas y sistemáticas a los Derechos Humanos. En este sentido, en el marco de implementación de mecanismos de justicia transicional, este instrumento contiene los estándares mínimos que deben ser implementados por el Estado frente a la reparación a las víctimas por violaciones de las normas internacionales y graves violaciones del DIH. En cuanto al derecho a la verdad, el instrumento establece que la verificación de los hechos y la revelación pública y completa de la verdad es la principal medida de satisfacción para las víctimas, de igual forma estipula la importancia de hacer de esa verdad un instrumento colectivo al solicitar a los Estados la inclusión de una exposición precisa de las violaciones ocurridas en la enseñanza de las normas internacionales de Derechos Humanos e invitar a facilitar las disculpas públicas y el reconocimiento de los hechos.

Se otorga una importancia central al derecho de acceso a la información pertinente sobre violaciones y mecanismos de reparación y se reconoce explícitamente el derecho de las víctimas, sus representantes y organizaciones de Derechos Humanos a conocer la verdad acerca de las violaciones a los Derechos Humanos. Este instrumento hace parte del estándar internacional que ha utilizado como base jurídica la Corte Interamericana de Derechos Humanos en diferentes casos y es a su vez el instrumento más citado por la Corte Constitucional y la Corte Suprema de Justicia frente al derecho de las víctimas a la reparación del daño por violaciones de las normas internacionales de Derechos Humanos y graves violaciones del Derecho Internacional Humanitario. 


\subsubsection{Conjunto de Principios para la Protección y la Promoción de los Derechos Humanos} mediante la lucha contra la impunidad ${ }^{11}$

Este instrumento es el primero en desarrollar de una manera profunda el derecho a la verdad, es de lejos el instrumento donde mejor se ve reflejado el desarrollo de este derecho y condensa los resultados de los diferentes estudios que fueron solicitados en el marco del Sistema de Naciones Unidas. Constituye además el mayor esfuerzo por combatir el fenómeno de la impunidad, y brindar directrices a los Estados para la superación de contextos caracterizados por violaciones sistemáticas y generalizadas de los Derechos Humanos.

El documento es el resultado de los estudios realizados por el experto sobre la impunidad de autores de violaciones a los derechos civiles y políticos, Louis Joinet, quien luego de sistematizar el desarrollo de la jurisprudencia y la doctrina internacionales de Derechos Humanos, llegó a la conclusión de que el derecho a la verdad o el derecho a saber, existe y es un derecho de carácter inalienable.

El 8 de febrero del año 2005 se presentó la última actualización de este instrumento. Esta nueva actualización fue elaborada por la experta Diane Orentlicher, quien estableció en su preámbulo:

convencida, en consecuencia, de la necesidad de adoptar a tal fin medidas nacionales e internacionales, para que, en interés de las víctimas de violaciones de los Derechos Humanos, se asegure conjuntamente el respeto efectivo del derecho a saber que entraña el derecho a la verdad, el derecho a la justicia y el derecho a obtener reparación, sin los cuales no puede haber recurso eficaz contra las consecuencias nefastas de la impunidad (Orentlicher, 2005, preámbulo).

El instrumento aborda cuatro pilares claves del derecho internacional de los derechos humanos, I) La lucha contra la impunidad, II) el Derecho a Saber, III) el Derecho a la Justicia y IV) el derecho a obtener reparación por las violaciones. El principio 1 del instrumento establece la obligación internacional de los Estados de adoptar medidas eficaces para luchar contra la impunidad, en este sentido, el derecho a saber es desarrollado a partir de 17 principios generales.

\footnotetext{
31 Documento de las Naciones Unidas E/CN.4/Sub.2/1997/Rev.1, Anexo I.
} 
El instrumento reafirma el derecho inalienable de saber la verdad con respecto a graves violaciones a los Derechos Humanos y otros crímenes de trascendencia internacional. Incluye el principio 2 el cual declara que toda persona tiene el derecho inalienable de saber la verdad sobre acontecimientos pasados relacionados con la consumación de crímenes atroces y sobre las circunstancias y razones que ocasionaron desde violaciones masivas o sistemáticas hasta la perpetración de estos crímenes, de igual forma entiende que hacer efectivo el derecho a la verdad contribuye fundamentalmente a la no repetición de las violaciones.

Para este estudio es pertinente el principio 3, mediante el cual consagró el deber de recordar, y estableció de una manera implícita el deber de memoria que constituye uno de los desarrollos más importantes de la Ley 1448 de 2011 y es a su vez el fundamento jurídico internacional para la creación en Colombia del Centro Nacional de Memoria Histórica (CNMH), mecanismos por medio de los cuales el legislador colombiano optó por emprender acciones en perspectiva de garantizar el derecho a la verdad desde su dimensión colectiva, a partir del deber de recordar o deber de memoria del Estado. Así quedó consagrado en el conjunto de principios:

Principio 3. Deber de Recordar: El conocimiento por un pueblo de la historia de su opresión forma parte de su patrimonio y, por ello, se debe conservar adoptando medidas adecuadas en aras del deber de recordar que incumbe al Estado para preservar los archivos y otras pruebas relativas a violaciones de los Derechos Humanos y el derecho humanitario y para facilitar el conocimiento de tales violaciones. Esas medidas deben estar encaminadas a preservar del olvido la memoria colectiva y, en particular, evitar que surjan tesis revisionistas y negacioncitas. (E/CN.4/Sub.2/1997/Rev.1, Anexo I)

El principio 4 consagra el derecho de las víctimas a saber y estipula que independientemente de cualquier procedimiento legal, tanto las víctimas como sus familias tienen el derecho imprescriptible de saber la verdad sobre la muerte 0 desaparición, sobre las circunstancias en las cuales las violaciones tuvieron lugar y, en casos de muerte o desaparición, sobre la suerte de la víctima. E principio 2 dispone que el Estado tiene la obligación de garantizar el derecho inalienable a conocer la verdad.

El principio 5 abre las puertas para el denominado margen de interpretación de los Estados en relación con el derecho a la verdad, dado que este principio le otorga al Estado la facultad para 
emprender medidas para hacer efectivo el derecho a saber, según sus propias particularidades y a partir de una amplia paleta de mecanismos, entre los cuales se encuentran las comisiones de la verdad, comisiones de investigación, así como mecanismos tanto de tipo judicial, administrativo y disciplinario. Este principio le impone una obligación internacional a los Estados en relación con la preservación de archivos, en cuanto le otorga a los Estados la posibilidad de garantizar el derecho a saber por una pluralidad de medios, es tajante en establecer, que en cualquiera de los mecanismos que se establezcan, los archivos deberán ser preservados y protegidos de su destrucción u ocultamiento, así como se debe garantizar su consulta.

Principio 5. Garantías para hacer efectivo el derecho a saber: Incumbe a los Estados adoptar las medidas adecuadas, incluidas las medidas necesarias para garantizar el funcionamiento independiente y eficaz del poder judicial, para hacer efectivo el derecho a saber. Las medidas apropiadas para asegurar ese derecho pueden incluir procesos no judiciales que complementen la función del poder judicial. Las sociedades que han experimentado crímenes odiosos perpetrados en forma masiva o sistemática pueden beneficiarse en particular con la creación de una comisión de la verdad u otra comisión de investigación con objeto de establecer los hechos relativos a esas violaciones de manera de cerciorarse de la verdad e impedir la desaparición de pruebas. Sea que un Estado establezca o no un órgano de ese tipo, debe garantizar la preservación de los archivos relativos a las violaciones de los Derechos Humanos y el derecho humanitario y la posibilidad de consultarlos. (E/CN.4/Sub.2/1997/Rev.1, Anexo I)

El derecho a saber de las víctimas de graves violaciones a los derechos humanos, establecido en el principio 4 del instrumento, le otorga además de su carácter inalienable, un carácter de imprescriptibilidad, características ambas de los derechos humanos fundamentales.

El derecho a la verdad entendido como el derecho a saber, estaría compuesto entonces por los principios generales, los cuales le otorgan un carácter imprescriptible e inalienable, desarrolla los mecanismos por medio de los cuales los Estados pueden garantizar su efectividad y establece el deber de recordar, derecho colectivo que le otorga un lugar especial a los procesos de reconstrucción de la memoria colectiva. 
Finalmente este instrumento consagra medidas y principios orientados al establecimiento de una comisión de la verdad, al tratamiento de los archivos de graves violaciones a los Derechos Humanos, desarrolla las obligaciones internacionales en cuanto a la garantía del derecho a la justicia y el derecho a obtener una reparación pronta y eficaz. Este conjunto de principios constituye parte fundamental de los denominados estándares internacionales en materia de derecho a la verdad, particularmente en contextos de negociación, reconciliación y/o de justicia transicional, su valor jurídico depende aun de un margen de apreciación por parte de los Estados, el cual se materializa a través del control de convencionalidad. En Colombia este instrumento aunque inscrito en el denominado derecho blando o soft law, ha quedado incorporado vía bloque de constitucionalidad como eje orientador frente al deber del Estado de reparar a las víctimas y de garantizar la efectividad del derecho a la verdad y la memoria histórica en contextos de justicia transicional.

\section{Conclusiones}

Como ya lo hemos venido diciendo a lo largo del documento el derecho a la verdad en contextos de justicia transicional adquiere una importancia central. En tanto en estos contextos los pronunciamientos de la Corte IDH han reiterado que el derecho a la verdad hace parte esencial de las medidas de reparación integral.

Los instrumentos que tanto la Corte IDH como la Corte Constitucional colombiana han utilizado para establecer estándares de aplicación, efectividad y garantía del derecho a la verdad en sus dimensiones individual y colectiva y que fueron analizados arriba, constituyen principios internacionales sobre impunidad y reparaciones y tal como lo estiman algunos autores consultados, y dada su incorporación vía bloque de constitucionalidad en el contexto de justicia transicional colombiano, constituyen además principios generales de derecho internacional por lo que el comportamiento del estado debe regirse por estos principios y su compromiso con la comunidad de naciones incluye la aplicación de su contenido. De esto se deriva, que su desconocimiento implicaría la violación del artículo 9 de la constitución política, en tanto las relaciones exteriores del Estado se fundamentan en el respeto a la soberanía nacional, la autodeterminación de los pueblos y los principios generales de derecho internacional aceptados por Colombia. (Gustavo Giraldo Gallon - Michael Reed Hurtado - Principios internacionales sobre impunidad y reparaciones) 
En contextos de justicia transicional se produce una intensa lucha en torno al derecho a la verdad. El contexto en cual se desarrollaron las graves violaciones a los derechos humanos es determinante a la hora de abordar los diferentes mecanismos para la garantía del derecho la verdad.

La masividad de la violencia, la duración del conflicto, el grado de involucramiento del Estado y el nivel de legitimidad que el proceso tenga frente a la sociedad civil y las víctimas, juega un papel determinante a la hora de establecer 0 adecuar instrumentos para la garantía y efectividad del derecho a la verdad. En un conflicto armado con las características del colombiano, en el cual además se presentaron sistemáticas violaciones a los derechos humanos, crímenes de lesa humanidad e infracciones a los derechos humanos en el marco no de un proceso dictatorial, si no el marco de una democracia, las medidas para la garantía del derecho a la verdad tanto desde su dimensión individual como colectiva, deben estar acompañadas indefectiblemente de medidas orientadas al reconocimiento de responsabilidades.

El mecanismo de comisión de la verdad debe ir acompañado de otra sería de instrumentos que permitan avanzar en la garantía del derecho a la verdad desde diferentes sectores sociales y políticos. La implementación de los estándares y principios de lucha contra la impunidad y reparaciones debe hacerse de forma integral.

La revisión de los estándares frente a la garantía del derecho a la verdad otorgan un amplio numero de instrumentos y mecanismos para su efectividad. La implementación de estos mecanismos debe atender las necesidades de las víctimas.

En contextos de justicia transicional, la verdad es una mirada al pasado, es importante que se acompañe de medidas orientadas a la construcción de la memoria histórica para facilitar la proyección del futuro y que al tiempo se avance en las investigaciones, en el esclarecimiento y en la aceptación de responsabilidades.

En el contexto latinoamericano, la corte y la comisión han asumido posiciones claras al respecto, y han establecido parámetros y estándares claros, que permiten a las víctimas, ante graves violaciones a los derechos humanos, acceder a medidas de reparación, y conocer la verdad como forma de combatir la impunidad. El Conjunto de Principios actualizado para la Protección y la Promoción de los Derechos Humanos mediante la Lucha contra la Impunidad (Conjunto de principios, 8 feb. 2005), los principios y directrices básicos sobre el derecho de las víctimas de violaciones 
manifiestas de las normas internacionales de Derechos Humanos y de violaciones graves del DIH a interponer recursos y obtener reparaciones (Resolución $N^{\circ} 60 / 147,16$ dic. 2005) y las Resoluciones 12/11 y 12/12 del Consejo de Derechos Humanos sobre Derechos Humanos, justicia de transición y derecho a la verdad, dan cuenta de ellos y constituyen el marco jurídico para la materialización del derecho a la verdad en contextos de justicia transicional. 


\subsection{El derecho a la verdad en la jurisprudencia Constitucional}

El derecho a la verdad en la jurisprudencia constitucional colombiana ha venido desarrollándose de manera paulatina, atendiendo a las necesidades de orden fáctico y socio político que han venido siendo abordadas por el Tribunal Constitucional. Uno de los aspectos que ha jalonado este proceso al interior de la Corte, está dado por la intención del Gobierno de implementar mecanismos jurídicos para facilitar acuerdos de negociación política con los actores armados y su consecuente desmovilización y reinserción. Es, en otras palabras, la implementación vía legislativa en Colombia, de mecanismos de justicia transicional, en cuyo centro se encuentra la tensión entre el cumplimiento de los estándares de justicia, verdad y reparación y el logro constitucional de la paz y la reconciliación. El análisis de esta tensión y de las problemáticas que se desprenden de esta, ha jalonado la producción constitucional de reglas frente a temas como reparación, conflicto armado, víctimas, delitos, graves violaciones a los Derechos Humanos y por supuesto sobre el derecho a la verdad, la memoria histórica y el deber de recordar. Para una mayor comprensión de la forma como se ha venido incorporando este derecho en nuestro sistema constitucional, propongo la siguiente organización por etapas en su desarrollo.

\subsubsection{El derecho a la verdad como elemento esencial del derecho a un recurso judicial efectivo de las víctimas de los delitos}

Desde el año 2002, la Corte Constitucional ha venido desarrollando una línea jurisprudencial en torno al derecho a la verdad 32 . Una de las primeras decisiones que aproximó el tema fue la sentencia C- 228 de 2002, sentencia fundamental en lo que a derechos de las víctimas se refiere. Por medio de esta, la Corte a través de un estudio de constitucionalidad, estableció los derechos de las víctimas de los delitos, incluyendo la denominada parte civil y a los perjudicados en el marco del proceso penal establecido en la Ley 600 de 2000. En esta sentencia, la Corte realiza un análisis de

32 La línea jurisprudencial sobre el derecho a la verdad la integran las siguientes jurisprudencias: T- 249/03, C-228/02, C580/02, C-875/02, C-370/06, C-454/06, C-516/07, C-209/07, C-516/07, C-208/08 y C-260/11. 
los derechos de la parte civil, la víctima y el perjudicado en el marco del proceso penal a partir de los preceptos constitucionales. De igual forma establece criterios en relación con los derechos de estas tres partes a partir del denominado bloque de constitucionalidad, a través del cual, construye una línea argumentativa que fundamenta en los estándares establecidos en el Derecho Internacional de los Derechos Humanos y en la jurisprudencia de la Corte Interamericana de Derechos Humanos. A continuación un extracto de la sentencia en mención:

Existe una tendencia mundial, que también ha sido recogida en el ámbito nacional por la Constitución, según la cual la víctima o perjudicado por un delito no sólo tiene derecho a la reparación económica de los perjuicios que se le hayan causado, trátese de delitos consumados o tentados, sino que además tiene derecho a que a través del proceso penal se establezca la verdad y se haga justicia. Esa tendencia se evidencia tanto en el texto constitucional como en el derecho internacional y el derecho comparado. (Sentencia C- 228 de 2002, M. J. Cepeda Espinosa y E. Montealegre Lynett)

Cómo se puede observar en esta cita, la Corte comienza desde este pronunciamiento, a establecer un marco jurídico de protección de los derechos de las víctimas. Esta sentencia representa un precedente, en el cual se establece un marco de protección a partir de la inclusión vía bloque de constitucionalidad de los diferentes estándares de reparación establecidos en los instrumentos de carácter internacional. En relación con el derecho a la verdad, se realiza una interpretación extensa a partir del desarrollo del derecho a un recurso judicial efectivo. El modelo sistemático de interpretación utilizado por la Corte Constitucional para ampliar los derechos de las víctimas, en particular el derecho a la verdad, se ilustra a continuación:

La visión tradicional de los derechos de las víctimas de un delito, restringida al resarcimiento económico se ha ido transformando en el derecho internacional, en particular en relación con las violaciones a los Derechos Humanos desde mediados del siglo XX, dentro de una tendencia hacia una concepción amplia del derecho a una tutela judicial idónea y efectiva, a través de la cual las víctimas obtengan tanto la reparación por el daño causado, como claridad sobre la verdad de lo ocurrido, y que se haga justicia en el caso concreto. La Constitución de 1991 recogió esta tendencia 
que cobró fuerza a finales de los años sesenta y se desarrolló en la década de los ochenta. (Sentencia C- 228 de 2002, M. J. Cepeda Espinosa y E. Montealegre Lynett)

El derecho a un recurso judicial efectivo encuentra su fundamentación en la Declaración Americana de los Derechos del Hombre $(1948)^{33}$, así como en la Declaración Universal de los Derechos Humanos (1948)34. A partir de su codificación en estos dos instrumentos, se marca el inicio de una tendencia en el DIDH por desarrollar instrumentos que garanticen a toda persona el derecho a una tutela judicial efectiva, a través de la cual, no solo obtengan reparación por el daño sufrido, si no también garantice sus derechos a la verdad y a la justicia.

En el marco del Sistema Interamericano de Protección de los Derechos Humanos, la Corte Interamericana ha venido desarrollando el derecho a la protección judicial ${ }^{35}$, y ha sostenido lo siguiente:

(...) la inexistencia de un recurso efectivo contra las violaciones a los derechos reconocidos por la Convención constituye una transgresión de la misma por el Estado Parte en el cual semejante situación tenga lugar. En ese sentido debe subrayarse que, para que tal recurso exista, no basta con que esté previsto por la Constitución o la ley o con que sea formalmente admisible, sino que se requiere que sea realmente idóneo

33Declaración Americana de los Derechos y Deberes del Hombre, OAS Res. XXX, aprobada en la Novena Conferencia Internacional Americana (1948), reimpresa en Documentos Básicos Concernientes a los Derechos Humanos en el Sistema Interamericano, OEA/Ser.L.V/LL2 doc.6 rev.1 p. 17 (1992). Artículo XVIII. Derecho de justicia. Toda persona puede ocurrir a los tribunales para hacer valer sus derechos. Asimismo debe disponer de un procedimiento sencillo y breve por el cual la justicia lo ampare contra actos de la autoridad que violen, en perjuicio suyo, alguno de los derechos fundamentales consagrados constitucionalmente.

34 Declaración Universal de Derechos Humanos, A.G. res. 217 A (III), ONU Doc. A/810 p. 71 (1948). Artículo 8. Toda persona tiene derecho a un recurso efectivo, ante los tribunales nacionales competentes, que la ampare contra actos que violen sus derechos fundamentales reconocidos por la constitución o por la ley.

35 Convención Americana de Derechos Humanos, Serie sobre Tratados, OEA, No. 36, 1144, Serie sobre Tratados de la ONU, 123 entrada en vigor 18 de julio de 1978, reimprimido en Documentos Básicos Concernientes a los Derechos Humanos en el Sistema Interamericano, OEA/Ser.L.V/ll.82 doc.6.rev.1 p. 25 (1992). Artículo 25. Protección Judicial. 1.Toda persona tiene derecho a un recurso sencillo y rápido 0 a cualquier otro recurso efectivo ante los jueces 0 tribunales competentes, que la ampare contra actos que violen sus derechos fundamentales reconocidos por la Constitución, la ley o la presente Convención, aun cuando tal violación sea cometida por personas que actúen en ejercicio de sus funciones oficiales. 2. Los Estados partes se comprometen: a) A garantizar que la autoridad competente prevista por el sistema legal del Estado decidirá sobre los derechos de toda persona que interponga tal recurso; b) A desarrollar las posibilidades de recurso judicial, y c) A garantizar el cumplimiento, por las autoridades competentes, de toda decisión en que se haya estimado procedente el recurso." 
para establecer si se ha incurrido en una violación a los Derechos Humanos y proveer

lo necesario para remediarla. (Corte Interamericana, OC-9/87, 6 oct.1987, párr. 24)

Frente al derecho a la verdad como elemento esencial del derecho a un recurso judicial efectivo, la Corte Constitucional ha interpretado que el mismo hace parte esencial del derecho a la protección judicial establecido en el artículo 25 de la Convención, el cual en el ámbito interamericano, equivale al recurso judicial efectivo. En igual sentido se ha expresado la Corte Europea de Derechos Humanos al invocar el artículo $47^{36}$ de la Carta de Derechos Fundamentales de la Unión Europea.

Como resultado de esta tendencia del Derecho Internacional de los Derechos Humanos, la comunidad internacional ha rechazado los mecanismos internos que conduzcan a la impunidad y al ocultamiento de la verdad de lo ocurrido. ${ }^{37}$ Si bien este consenso se refiere a violaciones graves a los Derechos Humanos, el lenguaje de los textos citados, así como la interpretación judicial de los mismos, tienen un alcance que rebasa tales delitos o crímenes. (Sentencia C- 228 de 2002, M. J. Cepeda Espinosa y E. Montealegre Lynett)

En conclusión, a partir de la jurisprudencia en mención, el derecho a la verdad comienza a ser un elemento esencial del denominado recurso judicial efectivo, o desde el punto de vista del ámbito interamericano, del derecho a la protección judicial, ambas obligaciones internacionales en cabeza del Estado, y a partir de esta sentencia, también en el ámbito interno. Finalmente, se puede decir que, la importancia de la sentencia C- 228 del año 2002, radica en el establecimiento de una regla de derecho de rango constitucional basada en el reconocimiento de tres elementos esenciales del denominado recurso judicial efectivo: I) El derecho a la verdad, esto es, la posibilidad de conocer lo que sucedió y en buscar una coincidencia entre la verdad procesal y la verdad real. Este derecho resulta

\footnotetext{
${ }^{36}$ Carta de Derechos Fundamentales de la Unión Europea, 2000 O.J. (C 364) 1, en vigor desde Dic. 7, 2000. Derecho a la tutela judicial efectiva y a un juez imparcial. Artículo 47. "Toda persona cuyos derechos y libertades garantizados por el Derecho de la Unión hayan sido violados tiene derecho a la tutela judicial efectiva respetando las condiciones establecidas en el presente artículo. Toda persona tiene derecho a que su causa sea oída equitativa y públicamente y dentro de un plazo razonable por un juez independiente e imparcial, establecido previamente por la ley. Toda persona podrá hacerse aconsejar, defender y representar. Se prestará asistencia jurídica gratuita a quienes no dispongan de recursos suficientes siempre y cuando dicha asistencia sea necesaria para garantizar la efectividad del acceso a la justicia."

37 Ver Cassel Jr., Douglas W. International Truth Commissions and Justice; Huyse, Luc. Justice after Transition: On the choices succesor elites make in dealing with the past". En: Transitional Justice, Volume I: General Considerations, pp 326349; Mendez, Juan E. The Right to Truth. En: Reigning in Impunity for International Crimes and Serious Violations of Fundamental Rights: Proceedings of The Siracusa Conference, pp. 17-21 Sept., 1998, Christopher C. Joyner Ed., 1998.
} 
particularmente importante frente a graves violaciones de los Derechos Humanos. ${ }^{38}$ II) El derecho a que se haga justicia en el caso concreto, es decir, el derecho a que no haya impunidad y III) El derecho a la reparación del daño que se le ha causado a través de una compensación económica, que es la forma tradicional como se ha resarcido a la víctima de un delito.

\subsubsection{El derecho a la verdad autónomo e inalienable}

Esta segunda etapa se caracteriza por la inclusión de dos elementos fundamentales, I) la manifestación expresa por parte de la Corte Constitucional de la naturaleza autónoma e inalienable del derecho a la verdad, y II) el desarrollo del derecho a la verdad como elemento fundamental de la denominada reparación integral de los daños producto de la comisión de graves violaciones a los Derechos Humanos, crímenes de lesa humanidad e infracciones al Derecho Internacional Humanitario en el marco del conflicto armado de carácter interno. Esta etapa la integran dos sentencias de la Corte Constitucional, sentencias C 370 de $2006^{39}$, hito frente al desarrollo de las medidas de reparación integral, justicia transicional y estandares de justicia y T - 576 de 2008 la cuál reivindica la autonomía e inalienabilidad del derecho a la verdad, con independencia del escenario en el cuál se haya realizado la violación ${ }^{40}$.

Por medio de la sentencia C- 370 de 2006 la Corte analizó una demanda de inconstitucionalidad presentada contra diversos artículos de la Ley 975 de 2005, en el entendido de que con ellos se afectaba el derecho a la verdad de las víctimas del conflicto armado y se desconocía por tanto los estándares internacionales relacionados con el derecho de las víctimas a una reparación

\footnotetext{
38 Ver, entre otros, los casos Velásquez Rodríguez (fundamento 166), Sentencia del 29 de julio de 1988 y Barrios Altos (fundamento 43), Sentencia de 14 de Marzo de 2001 de la Corte Interamericana de Derechos Humanos, donde la Corte resalta como contrarios a la Convención Americana aquellos instrumentos legales desarrollados por los Estados partes que le nieguen a las víctimas su derecho a la verdad y a la justicia.

${ }^{39}$ Sentencia por medio de la cual se analizan cargos de inconstitucionalidad en contra de 23 artículos de la Ley 975 de 2005 o "Ley de Justicia y Paz," Por medio de la cual se dictan disposiciones para la reincorporación de miembros de grupo armados al margen de la ley, que contribuyan de manera efectiva a la consecución de la paz nacional y se dictan otras disposiciones para acuerdos humanitarios.

${ }^{40}$ Acción de tutela instaurada en contra de SaludCoop, por la muerte de un menor de edad por negación de los servicios de salud. Si bien esta sentencia no guarda estrecha relación con el derecho a la verdad en el contexto de la justicia transicional, es sobremanera relevante en cuanto establece la relación del derecho a la verdad, con la garantía de realización del Estado Social de Derecho y, el derecho a la dignidad humana.
} 
integral como consecuencia de la comisión de crímenes sistemáticos y violaciones generalizadas a los derechos humanos.

En esta sentencia se establece el contenido mínimo del derecho a la verdad en sus dimensiones, individual, colectiva y estatal, se realiza una ponderación entre el derecho a la justicia y los derechos a la paz, la verdad y la reparación y se establecen principios en relación con la garantía del derecho a la verdad en procesos de transición.

En cuanto al primer asunto, la Corte establece que el derecho de las víctimas a la verdad salvaguarda en primer lugar, el derecho a que los delitos más graves sean investigados, lo cual implica que el Estado es responsable por acción o por omisión si no hay una investigación seria, acorde con la normatividad nacional e internacional. Por otra parte se establece la obligación del Estado de crear medidas que sancionen el fraude a la justicia, así como medidas que en el marco de procesos de justicia transicional establezcan mecanismos idóneos para la consecución de la verdad.

En cuanto a la dimensión colectiva, el contenido mínimo del derecho a la verdad según la Corte debe incluir tres elementos: I) la posibilidad de las sociedades de conocer su propia historia, II) la posibilidad elaborar un relato colectivo relativamente fidedigno sobre los hechos que la han definido y III) la posibilidad de adelantar investigaciones judiciales imparciales, integrales y sistemáticas sobre los hechos sobre los cuales se pretende dar cuenta. Estos tres elementos vendrían a conformar requisitos constitucionales para la implementación de una política de verdad y memoria histórica.

Frente a este punto la sentencia manifiesta:

La sociedad en su conjunto tiene derecho a conocer la conducta de quienes se hayan involucrado en la comisión de violaciones graves a los Derechos Humanos o el Derecho Internacional Humanitario, especialmente en caso de masividad 0 sistematicidad; comprender los elementos de carácter objetivo y subjetivo que contribuyeron a crear las condiciones y circunstancias dentro de las cuales conductas atroces fueron perpetradas e identificar los factores de índole normativa y fáctica que dieron lugar a la aparición y el mantenimiento de las situaciones de impunidad; contar con elementos para establecer si los mecanismos estatales sirvieron de marco a la consumación de conductas punibles; identificar a las víctimas y sus grupos de pertenencia, así como a quienes hayan participado de actos de victimización; y 
comprender el impacto de la impunidad (Sentencia C- 370 de 2006, M.J. Cepeda, J. Córdova, R. Escobar et al).

Frente a la dimensiones del derecho a la verdad, la sentencia incluye, una dimensión individual que se entiende como el derecho a saber; otra colectiva como el derecho inalienable a la verdad; y otra estatal que se expresa en el deber de recordar. Adicionalmente, dice la sentencia, se trata de un derecho (derecho a la verdad) el cual comporta el derecho a la no repetición de las conductas y el derecho a la reparación.

Con el fin de analizar si las penas alternativas establecidas en la Ley 975 de 2005 eran contrarias al derecho a la justicia, la verdad y la reparación, la Corte incluyó un juicio de ponderación mediante el cual pretendió esclarecer si las penas alternativas y los procedimientos específicos se ajustan a las normas constitucionales y si la afectación al valor justicia es viable en razón a la búsqueda de otros valores constitucionales como el derecho a la paz, el derecho a la verdad y la reparación de las víctimas. La Corte al introducir esta perspectiva de análisis ubica el derecho a la verdad en un extremo y el derecho a la justicia en otro, a partir de esto, establece principios específicos sin los cuales la garantía del derecho a la verdad resultaría inocua. Así se estable en la sentencia:

En efecto, como se señaló anteriormente, en la ley demandada se establecen diferentes mecanismos -como la alternatividad penal y reglas procesales específicasque implican, de entrada, una afectación del valor objetivo de la justicia y del derecho correlativo de las víctimas a la justicia. Por lo tanto, al juzgar los beneficios penales, uno de los extremos de la ponderación ha de ser el de la justicia, como valor y como derecho de las víctimas. La ponderación se ha de llevar a cabo, en consecuencia, entre las diferentes maneras en que las normas demandadas afectan la justicia, y los demás valores y derechos constitucionales a proteger, a saber: la paz, el derecho a la verdad, el derecho a la reparación y el derecho a la no repetición de las conductas violatorias de Derechos Humanos (Sentencia C- 370 de 2006, M.J. Cepeda, J. Córdova, R. Escobar et al)

La Corte concluyó que en materia penal el legislador puede optar por mecanismos amplios en perspectiva de buscar valores de máximo rango constitucional como lo son la paz y el derecho a la verdad frente a lo cual determinó: "un instrumento que limita el alcance del derecho a la justicia, puede 
a su turno promover el derecho a la verdad". (Sentencia C- 370 de 2006, M.J. Cepeda, J. Córdova, R. Escobar et al).

En relación con el contenido mínimo del derecho a la verdad, la Corte determina que varios de los artículos demandados están en contravía de este derecho y establece los siguientes principios frente a su garantía y efectividad:

$\checkmark \quad$ El derecho a la verdad incorpora el derecho a conocer las causas y las circunstancias de tiempo, modo y lugar en las que los delitos fueron cometidos. Todo esto conduce a que la víctima vea públicamente reconocido su dolor y su plena ciudadanía en términos de su reconocimiento como sujeto de derechos. Así mismo, conduce a que las personas afectadas puedan saber, si así lo desean, las razones y condiciones en las cuales se cometió el delito.

$\checkmark \quad$ Cuando se trata del delito de desaparición forzada de personas, el derecho a la verdad apareja el derecho a conocer el destino final de la persona desaparecida. Según lo ha establecido la jurisprudencia internacional, mantener a los familiares de una víctima de desaparición forzada en la incertidumbre sobre el destino de su ser querido, vulnera el derecho a no ser sometido a tratos crueles, inhumanos o degradantes.

$\checkmark \quad$ En cuanto se refiere a la dimensión colectiva de la verdad, su contenido mínimo incluye la posibilidad de las sociedades de conocer su propia historia, de elaborar un relato colectivo relativamente fidedigno sobre los hechos que la han definido y de tener memoria de tales hechos. Para ello, es necesario que se adelanten investigaciones judiciales imparciales, integrales y sistemáticas, sobre los hechos criminales de los que se pretende dar cuenta histórica. Un sistema que no beneficie la reconstrucción de la verdad histórica o que establezca apenas débiles incentivos para ello, podría comprometer este importante derecho.

La Corte también concluye, para declarar la inconstitucionalidad de varios de los artículos demandados, que la ley demandada no establece claramente los mecanismos judiciales necesarios y suficientes para que se pueda esclarecer el fenómeno macrocriminal que se pretende afrontar. Tampoco establece mecanismos judiciales que aseguren la revelación de la verdad sobre los delitos concretos cometidos por los integrantes de los grupos específicos que se desmovilicen. 
Por último, hacemos referencia a la sentencia T- 576 de 2008 por medio de la cual la Corte Constitucional, en sede de tutela se pronunció frente a la violación del derecho fundamental a la verdad de una madre a cuyo hijo menor le fueron negados los servicios médicos por parte de SaludCoop produciéndole la muerte. Esta sentencia resulta especialmente relevante en este apartado, por cuanto incluye con fuerza normativa el carácter autónomo e inalienable del derecho a la verdad. De la misma forma, esta sentencia permite entender el derecho a saber vinculado con el acceso y garantía de otros derechos, así como lo relaciona con la realización efectiva del Estado social de derecho y con los objetivos de una sociedad en vía de fortalecimiento de su democracia.

El derecho a la verdad respecto de graves y serias violaciones de Derechos Humanos y del Derecho Internacional Humanitario constituye un derecho autónomo, inalienable e imprescriptible, reconocido tanto en el campo nacional y regional, como en el internacional. Está conectado con el deber de conducir investigaciones efectivas cuando se han presentado serias violaciones de Derechos Humanos y con la obligación de ofrecer remedios eficaces y una justa reparación. De esta manera, se vincula asimismo con la garantía de realización del Estado Social de Derecho y, en consecuencia, se liga con los principios de transparencia, rendición de cuentas y buen gobierno en una sociedad democrática. Se relaciona, por lo demás, con la efectiva puesta en vigencia de otros derechos tales como el derecho a tener una vida en familia, el derecho a que se efectúe una investigación, el derecho a ser oído por un tribunal imparcial e independiente, el derecho a estar libre de tortura y de tratamientos crueles y degradantes, el derecho a buscar y a proporcionar información. En últimas, el derecho a la verdad se ata de manera profunda con el derecho a la dignidad humana de toda persona y tiene también un matiz social indeclinable. Su efectiva garantía contribuye a construir el tejido social sobre la base de la buena fe y de la confianza legítima, ingredientes sin los cuales toda sociedad está condenada a sucumbir en el círculo vicioso de la mentira, de la desconfianza, de la venganza y de la violencia. (Sentencia C- 370 de 2006, M.J. Cepeda, J. Córdova, R. Escobar et al). 


\subsubsection{Criterios jurisprudenciales sobre el derecho a la verdad}

Esta tercera y última etapa se caracteriza por la vinculación de precedentes constitucionales jurisprudenciales, y principios y reglas claros frente al derecho a la verdad. Está integrada por las sentencias C- 771 de 201141 y C- 715 de $2012^{42}$.

En cuanto a los estándares, la Corte reconoce que existe un marco jurídico internacional que desarrolla el derecho a la verdad, el cual se encuentra consagrado en los Principios para la protección y promoción de los Derechos Humanos mediante la lucha contra la impunidad (principios 1 al 4), reconoce la relación entre el derecho a la verdad y el principio de dignidad humana, en el deber de memoria histórica y de recordar, así como en el derecho al buen nombre y a la imagen.

Se reconoce también, el carácter inalienable del derecho a la verdad, su carácter individual y colectivo como derecho de las víctimas, sus familiares, perjudicados y la sociedad en su conjunto cuando se trata de contextos de masividad y sistematicidad caracterizados por la ocurrencia de graves violaciones a los Derechos Humanos.

Frente a la dimensión individual del derecho a la verdad, la Corte establece que hacer efectivo este derecho implica que las víctimas y sus familiares conozcan la verdad sobre los hechos, los responsables y las consecuencias de lo sucedido. Igualmente "apareja por tanto, el derecho a conocer la autoría del crimen, los motivos y las circunstancias de tiempo, modo y lugar en que ocurrieron los hechos delictivos, y finalmente el patrón criminal que marca la comisión de los hechos criminales. Esto último, implica el derecho a conocer si el delito que se investiga constituye una grave violación a los Derechos Humanos, un crimen de guerra o un crimen de lesa humanidad". (Sentencia C-771 de 2011)

La dimensión colectiva del derecho a la verdad por su parte, significa que la sociedad debe conocer la realidad de lo sucedido, su propia historia, la posibilidad de elaborar un relato colectivo a través de la divulgación pública de los resultados de las investigaciones, e implica la obligación de

\footnotetext{
${ }^{41}$ Por medio de esta sentencia la Corte Constitucional avaló la constitucionalidad de la Ley 1424 de 2010 por medio de la cual se dictan disposiciones de justicia transicional que garanticen verdad, justicia y reparación a las víctimas de desmovilizados de grupos organizados al margen de la ley, se conceden beneficios jurídicos y se dictan otras disposiciones.

42 Por medio de esta sentencia la Corte Constitucional revisó cargos de inconstitucionalidad frente a la Ley 1448 de 2011 en los apartes orientados al proceso establecido para la restitución de tierras a los despojados.
} 
contar con una "memoria pública" sobre los resultados de estas investigaciones sobre graves violaciones de Derechos Humanos.

El derecho a la verdad según la Corte constituye un derecho imprescriptible y por tanto puede y debe ser garantizado en todo tiempo, con su garantía se busca entre otros objetivos, la coincidencia entre la verdad procesal y la verdad real. Se encuentra intrínsecamente relacionado y conectado con el derecho a la justicia y a la reparación y constituye un elemento fundamental frente a la garantía del derecho de acceso a la justicia, en cuanto esta, "sólo es posible si se proscribe la impunidad y se garantiza, a través de investigaciones serias, responsables, imparciales, integrales y sistemáticas por parte del Estado, el consecuente esclarecimiento de los hechos y la correspondiente sanción".(Sentencia C- 771 de 2011, MP Nilson Pinilla Pinilla).

Para la Corte, el derecho a la verdad se encuentra íntimamente vinculado con el derecho a la reparación, en tanto el conocimiento de lo sucedido para las víctimas y sus familiares, constituye un medio de reparación. Así mismo es enfática en reconocer el derecho de los familiares de las personas víctimas de desaparición forzada de conocer el destino de los desaparecidos y el estado y resultado de las investigaciones oficiales. En este sentido, el derecho a conocer el paradero de las personas desaparecidas o secuestradas se encuentra amparado en el derecho del familiar o allegado de la víctima a no ser objeto de tratos crueles, inhumanos o degradantes y debe ser satisfecho, incluso, si no existen procesos penales en contra de los presuntos responsables (por muerte, indeterminación o cualquier otra causa) $)^{43}$.

Finalmente la Corte establece, no solo la importancia y la obligación del Estado de adelantar investigaciones criminales con el fin de esclarecer la responsabilidad penal individual y la verdad de los hechos, sino también la importancia de mecanismos alternativos de reconstrucción de la verdad histórica, como comisiones de la verdad de carácter administrativo, que en casos de vulneraciones masivas y sistemáticas de los Derechos Humanos, deben servir a los fines constitucionales antes

\footnotetext{
${ }^{43}$ La Corte Interamericana de Derechos Humanos y el Tribunal Europeo de Derechos Humanos han estimado que las personas que ignoran el paradero de familiares desaparecidos se encuentran en una situación tal de angustia y ansiedad que encuentran violado su derecho a la integridad psíquica y moral, y lo establecido en la Convención de 10 de diciembre de 1984, por tanto, constituyen un trato cruel, inhumano o degradante. Al respecto se puede consultar, entre otras, la sentencia de la Corte Interamericana de Derechos Humanos en el Caso Blake, (Sentencia 24 ene. 1998); Caso Villagrán Morales y otros, (Sentencia 19 nov. 1991); caso Bámaca Velásquez, (Sentencia 8 nov. 2000).
} 
mencionados.

\section{Conclusiones}

La paulatina incorporación del derecho a la verdad en el sistema normativo colombiano, es una respuesta a la necesidad siempre presente de brindar herramientas jurídicas que se adapten a los procesos de negociación entre el gobierno colombiano y los grupos armados ilegales, facilitando la desmovilización de estos grupos y su posterior reintegración.

Como bien se ha dicho en capítulos anteriores, el conflicto armado colombiano y las masivas violaciones a los derechos humanos que en este contexto se han perpetrado, presentan un reto en términos del balance entre justicia y paz, siendo el derecho a la verdad un componente central de este debate.

En nuestro país, la corte constitucional sienta un precedente a partir de la Sentencia C- 228 de 2002, estableciendo que el derecho a la verdad, se incorpora dentro del componente de reparación integral a las víctimas, que va más allá de la reparación monetaria.

Partiendo del consenso internacional en cuanto al rechazo de los mecanismos que promuevan la impunidad en casos de sistematicidad de las violaciones a los derechos humanos, se asimila el concepto del deber de la aplicación del recurso judicial efectivo, en otras palabras, se vincula el derecho a la verdad con el derecho a la justicia.

En este sentido, el derecho a la verdad toma una doble connotación: Como un derecho no sólo de las víctimas sino de la sociedad en su conjunto, la cual tiene derecho a conocer la conducta de quienes se hayan involucrado en la comisión de los hechos; comprender los elementos de carácter objetivo y subjetivo que contribuyeron a crear las condiciones y circunstancias dentro de las cuales conductas atroces fueron perpetradas e identificar los factores que dieron lugar a la aparición y el mantenimiento de las situaciones de impunidad. Por otra parte, se plantea como un deber del Estado, tanto de investigar los hechos para encontrar la verdad judicial, como de recordar, garantizando así la no repetición de los hechos y la reparación simbólica a las víctimas a través de su dignificación.

Por tanto el derecho a la verdad se configura como un derecho de carácter autónomo, que si bien tiene relación con otros derechos, no pierde esta característica y debe ser entendido y defendido como tal y en segundo lugar adquiere un carácter inalienable, en tanto desborda su carácter individual 
como el derecho de las víctimas a saber y toma una dimensión colectiva y una importancia para la sociedad en su conjunto. Finalmente, este derecho toma una especial relevancia para el Estado, quien tiene el deber de garantizarlo a través de la implementación de mecanismos que permitan esclarecer la verdad, luchar contra la impunidad y garantizar no sólo la reparación a las victimas sino además, la no repetición de los hechos.

Por último, la jurisprudencia constitucional estableció reglas frente a la efectividad y garantía del derecho a la verdad, desbordando inclusive su relación con el conflicto armado y extendiéndola a todas las víctimas de los delitos. En punto a la dimensión colectiva del derecho, establece tres reglas de suma importancia para la implementación de mecanismos de justicia transicional en contextos de negociación política con los grupo armados. Esto es, la posibilidad de las sociedades de conocer su propia historia, la posibilidad de elaborar un relato colectivo relativamente fidedigno sobre los hechos que la han definido y la posibilidad de adelantar investigaciones imparciales, integrales y sistemáticas sobre los hechos sobre los cuales se pretende dar cuenta. Estas tres reglas hacen parte de lo que en Colombia se ha llamado el deber de memoria del Estado y deben ser aplicadas para que los ejercicios de construcción de memoria histórica aporten a la garantía y efectividad del derecho a la verdad, campos con dimensiones distintas.

\section{DERECHO A LA VERDAD EN EL CONTEXTO DE JUSTICIA TRANSICIONAL COLOMBIANO}

A partir del año 1997 el Estado colombiano inició una adopción legislativa orientada a facilitar la desmovilización, el desarme y la reinserción de miembros de grupos armados organizados al margen de la ley, así como la implementación de mecanismos para atender a las víctimas del conflicto armado. En este contexto se expidieron, entre otras, la Ley 418 de $1997^{44}$ que sería prorrogada y adicionada posteriormente por las leyes 548 de 1999, 782 de 2002, 1106 de 2006 y 1421 de 2010. El

\footnotetext{
44 Por medio de la Ley 418 de 1997 se crearon "Instrumentos para la búsqueda de la convivencia y la eficacia de la justicia, y se establecieron otras disposiciones".
} 
objetivo de estas leyes fue aplicar el indulto y la amnistía a miembros de grupos armados a partir de la aplicación de la figura de los delitos políticos ${ }^{45}$.

A partir de la lectura de estas normas, se puede concluir que ninguna de ellas estableció mecanismos claros para la búsqueda de la verdad, entre otras debido a que para ese momento Colombia no tenía desarrollado un marco jurisprudencial constitucional que protegiera los derechos a la verdad, la justicia y la reparación de las víctimas ${ }^{46}$. Además de esto, aún se mantenía un sistema penal de corte inquisitivo que no favorecía la búsqueda de la verdad procesal, cuestión que vino a cambiar en el año 2004, a partir de la implementación del sistema procesal penal oral de corte adversativo, el cual desarrolló amplias garantías para la búsqueda de la verdad, la justicia y la reparación para las víctimas de los delitos ${ }^{47}$.

Fue a partir de la Ley 975 de 2005 y fundamentalmente después de su revisión constitucional a partir de la sentencia C-370 de 2006, cuando inicia en Colombia el desarrollo del derecho a la verdad como elemento escencial del derecho a la reparación y como pilar fundamental del Estado social de derecho y de la democracia.

\subsection{Ley 975 de 2005 o Ley de Justicia y Paz ${ }^{48}$}

La ley de Justicia y Paz, Ley 975 de 2005, estableció el marco jurídico que reguló el proceso de desarme, desmovilización y reinserción de miembros de grupos armados al margen de la ley. Esta

\footnotetext{
45 La sala de casación penal de la Corte Suprema de Justicia ha establecido que el delito político tiene ocurrencia cuando se atenta contra el régimen constitucional y legal vigente en búsqueda de un nuevo orden.

${ }^{46}$ Estos marcos normativos, aunque hacen parte fundamental como antencedentes frente a los procesos de diálogo y negociación política entre el Estado y los actores armados, no incluyeron medidas orientadas a reparar a las víctimas de graves violaciones a los derechos humanos, crimenes de lesa humanidad e infracciones al Derecho Internacional Humanitario. en algunos casos se incorporaron medidas de corte humanitario y asistencial.
}

47 La ley 906 de 2004, que establece la estructura para la puesta en marcha del sistema penal acusatorio, sienta un precedente en términos de verdad, la justicia y la reparación como un imperativo categórico en materia de garantías de os derechos de las víctimas.

48 "Por la cual se dictan disposiciones para la reincorporación de miembros de grupos armados organizados al margen de la ley, que contribuyan de manera efectiva a la consecución de la paz nacional y se dictan otras disposiciones para acuerdos humanitarios". 
ley buscaba entre otros: facilitar los procesos de paz y la reincorporación individual o colectiva a la vida civil de miembros de grupos armados al margen de la ley; garantizar los derechos de las víctimas a la verdad, a la justicia y a la reparación integral en la búsqueda de la paz y la reconciliación nacional, y facilitar los acuerdos humanitarios. En el procedimiento judicial de carácter penal, excepcional y de justicia transicional que establece dicha ley, existe la etapa de versiones libres, en la cual los postulados, miembros de grupos paramilitares desmovilizados en el marco del proceso de desmovilización realizado entre las AUC y el gobierno del Álvaro Uribe, debían confesar de forma completa y veraz todos los delitos en los que hayan participado, todos los que han cometido o todos aquellos de los cuales tengan conocimiento; informar sobre las circunstancias de tiempo, modo y lugar en que ocurrieron los delitos; e indicar todos los bienes de origen licito e ilícito que tenga, directamente 0 a través de testaferros, con el fin de que estos bienes sean entregados y sirvan para garantizar la reparación a las víctimas.

Una vez entró en vigor, la Ley de Justicia y Paz fue demandada ante la Corte Constitucional por vicios de inconstitucionalidad y dentro de la gran mayoría de cargos presentados por las organizaciones defensoras de los Derechos Humanos, se encontraban cargos basados en la violación al derecho a la verdad de las víctimas y de la sociedad en su conjunto. Por tanto, a partir de la sentencia C- 370 de 2006 se declaró la constitucionalidad condicionada de varios artículos con el fin de proteger los derechos a la verdad, la justicia y la reparación.

A partir del artículo $4^{\circ 49}$ de la Ley, se establece la importancia del derecho a la verdad en el contexto del proceso de reconciliación nacional. Mediante el decreto 3391 de $2006^{50}$ se establece un número plural de programas restaurativos orientados a atender el desarrollo humano y social de las víctimas dentro de los cuales se establece la creación de programas orientados a la reconstrucción de la memoria histórica dentro de los procesos de reconciliación nacional.

\footnotetext{
${ }^{49}$ Artículo $4^{\circ}$. Derecho a la verdad, la justicia y la reparación y el debido proceso. El proceso de reconciliación nacional al que dé lugar la presente ley, deberá promover, en todo caso, el derecho de las víctimas a la verdad, la justicia y la reparación y respetar el derecho al debido proceso y las garantías judiciales de los procesados.

50 Por medio del cual se reglamentó la Ley 975 de 2005.
} 
El artículo $7^{051}$ de la Ley de Justicia y Paz estableció el derecho a la verdad como un derecho tanto de las víctimas como de la sociedad en su conjunto, por tanto incluyó el derecho a la verdad desde sus dimensiones individual y colectiva, haciendo referencia también al derecho a la verdad, como el derecho a la información dentro de los procesos judiciales y como derecho a saber el paradero de las víctimas de secuestro y desaparición forzada. Este artículo abrió la puerta para que en el futuro se implementen en Colombia otros mecanismos tanto judiciales como no judiciales para la reconstrucción de la verdad.

Dentro de los principios procesales que orientan este marco jurídico penal de excepción, se establece el esclarecimiento de la verdad ${ }^{2}$, principio que le impone a los servidores públicos la obligación de utilizar todos los medios disponibles y necesarios para que se asegure el esclarecimiento de la verdad sobre los hechos objeto de investigación. En este mismo principio se incluye la obligación de los fiscales de establecer en el transcurso de las investigaciones, las circunstancias de tiempo, modo y lugar en que se realizaron las conductas punibles. Se podría decir que la Ley 975 de 2005 incluyó el esclarecimiento de la verdad como núcleo esencial del derecho a la verdad desde su dimensión individual y colectiva, observemos el párrafo al cual se hace referencia:

\footnotetext{
${ }^{51}$ Artículo $7^{\circ}$. Derecho a la verdad. La sociedad, y en especial las víctimas, tienen el derecho inalienable, pleno y efectivo de conocer la verdad sobre los delitos cometidos por grupos armados al margen de la ley, y sobre el paradero de las víctimas de secuestro y desaparición forzada.

Las investigaciones y procesos judiciales a los que se aplique la presente ley deben promover la investigación de lo sucedido a las víctimas de esas conductas e informar a sus familiares lo pertinente.

Los procesos judiciales que se adelanten a partir de la vigencia de la presente ley no impedirán que en el futuro puedan aplicarse otros mecanismos no judiciales de reconstrucción de la verdad.

52 Artículo 15. Esclarecimiento de la Verdad. Dentro del procedimiento que establece la presente Ley los servidores públicos dispondrán lo necesario para que se asegure el esclarecimiento de la verdad sobre los hechos objeto de investigación y se garantice la defensa de los procesados.

La Unidad Nacional de Fiscalías para la Justicia y la Paz creada por esta ley, deberá investigar, por conducto del fiscal delegado para el caso, con el apoyo del grupo especializado de policía judicial, las circunstancias de tiempo, modo y lugar en que se realizaron las conductas punibles; las condiciones de vida, sociales, familiares, e individuales del imputado 0 acusado y su conducta anterior, los antecedentes judiciales y de policía, y los daños que individual o colectivamente haya causado de manera directa a las víctimas, tales como lesiones físicas o psicológicas, sufrimiento emocional, perdida financiera o menoscabo sustancial de derechos fundamentales.

Con la colaboración de los desmovilizados, la policía judicial investigará el paradero de las personas secuestradas o desaparecidas, e informará oportunamente a los familiares sobre los resultados obtenidos.

La Fiscalía General de la Nación velará por la protección de las víctimas, los testigos y los peritos que pretenda presentar en juicio. La protección de los peritos y testigos que pretenda presentar la defensa estará a cargo de la defensoría del pueblo. La protección de los magistrados de los tribunales Superiores de Distrito Judicial que deban conocer el juzgamiento será responsabilidad del Consejo Superior de la Judicatura.
} 
La Unidad Nacional de Fiscalía para la Justicia y la Paz creada por esta ley, deberá investigar, por conducto del fiscal delegado para el caso, con el apoyo del grupo especializado de policía judicial, las circunstancias de tiempo, modo y lugar en que se realizaron las conductas punibles; las condiciones de vida, sociales, familiares e individuales del imputado o acusado y su conducta anterior; los antecedentes judiciales y de policía, y los daños que individual o colectivamente haya causado de manera directa a las víctimas, tales como lesiones físicas o sicológicas, sufrimiento emocional, pérdida financiera o menoscabo sustancial de derechos fundamentales (art 15) (subrayado fuera del texto).

Otra de las formas por medio de la cuales se inscribe el derecho a la verdad dentro de la Ley de Justicia y Paz, es a partir de las medidas de satisfacción y garantías de no repetición $n^{53}$. Desde esta perspectiva el Estado está en el deber de incluir medidas orientadas a la verificación de los hechos y la difusión pública y completa de la verdad judicial. La Ley en mención también estableció la creación de la Comisión Nacional de Reparación y Reconciliación (CNRR) cuyo mandato incluyó "presentar un informe público sobre las razones para el surgimiento y evolución de los grupos armados ilegales" (art 51.2) y se establece igualmente un capítulo orientado a la protección de los archivos para facilitar la

${ }^{53}$ Artículo 48. Medidas de satisfacción y garantías de no repetición. Las medidas de satisfacción y las garantías de no repetición, adoptadas por las distintas autoridades directamente comprometidas en el proceso de reconciliación nacional, deberán incluir:

48.1 La verificación de los hechos y la difusión pública y completa de la verdad judicial, en la medida en que no provoque más daños innecesarios a la víctima, los testigos u otras personas, ni cree un peligro para su seguridad.

48.2 La búsqueda de los desaparecidos o de las personas muertas y la ayuda para identificarlas y volverlas a inhumar según las tradiciones familiares y comunitarias. Esta tarea se encuentra principalmente a cargo de la Unidad Nacional de Fiscalías para la Justicia y la Paz.

48.3 La decisión judicial que restablezca la dignidad, reputación y derechos de la víctima y las de sus parientes en primer grado de consanguinidad.

48.4 La disculpa, que incluya el reconocimiento público de los hechos y la aceptación de responsabilidades.

48.5 La aplicación de sanciones a los responsables de las violaciones, todo lo cual estará a cargo de los órganos judiciales que intervengan en los procesos de que trata la presente ley.

48.6 La sala competente del Tribunal Superior de Distrito judicial podrá ordenar conmemoraciones, homenajes y reconocimiento a las víctimas de los grupos armados al margen de la ley. Adicionalmente, la Comisión Nacional de

Reconciliación y Reparaciones podrá recomendar a los órganos políticos o de gobierno de los distintos niveles, la adopción de este tipo de medidas.

48.7 La prevención de violaciones de Derechos Humanos.

48.8 La asistencia a cursos de capacitación en materia de Derechos Humanos a los responsables de las violaciones. Esta medida podrá ser impuesta a los condenados por la sala competente Tribunal Superior de Distrito Judicial. 
reconstrucción de la memoria histórica (art. 56), el deber de memoria del estado (art. 57) y derecho a la información y preservación de los archivos (art. 58) ${ }^{54}$.

Teniendo en cuenta lo anterior puede decirse que en general, la ley 975 de 2005 incorporó elementos esenciales que dan cuenta de la importancia del derecho a la verdad dentro de un esquema de justicia transicional. Si bien, en un primer momento la ley se orientó hacia la materialización de una verdad judicial, en la cual los excombatientes se acogían al cumplimiento de condiciones para el esclarecimiento de la verdad que les garantizara acceder a los beneficios de alternatividad establecidos en la ley (Arango, 2007, p.289), la posterior creación de la CNRR reorientó este enfoque y permitió un trabajo complementario en el cual el trabajo de reconstrucción de memoria, centrado en las víctimas y comunidades permitió entender el derecho a la verdad como un derecho multidimensional, en el cuál la verdad es una construcción colectiva desde la memoria de todos los involucrados en la historia del territorio.

La Sentencia C-370 de 2006 estudia algunas cuestiones que ejemplifican mejor esta dualidad. Al analizar la ley se observa que algunos incisos de los artículos 48 y 58 de la ley 975 establecen el deber de difusión pública y completa de la verdad judicial siempre y cuando no provoque más daños a las víctimas u otras personas, no atente contra la seguridad y no viole el derecho a la intimidad. Si bien, en el de la ley 975 , el establecimiento de estas restricciones puede constituir una violación al derecho al acceso a la información, y por tanto impedir el acceso a la verdad por parte de la sociedad en general (Arango, 2007, p.300-302), el Centro Nacional de Memoria histórica ha jugado un rol determinante para contrarrestar estas falencias. A través de informes como "Crímenes que no

\footnotetext{
${ }^{54}$ Capítulo X Conservación de Archivos

Artículo 56. Deber de Memoria. El conocimiento de la historia de las causas, desarrollos y consecuencias de la acción de los grupos armados al margen de la ley deberá ser mantenido mediante procedimientos adecuados, en cumplimiento del deber a la preservación a la memoria histórica que corresponde al Estado.

Artículo 57. Medidas de Preservación de los Archivos. El derecho a la verdad implica que sean preservados los archivos. Para ello los órganos judiciales que los tengan a su cargo, así como la procuraduría general de la Nación, deberán adoptar las medias para impedir la sustracción, la destrucción o la falsificación de los archivos, que pretendan imponer la impunidad. Lo anterior sin perjuicio de las normas penales pertinentes.

Artículo 58. Medidas para facilitar el acceso a los archivos. El acceso a los archivos debe ser facilitado en el interés de las víctimas y de sus parientes para hacer valer sus derechos.

Cuando el acceso se solicite en interés de la investigación histórica, las formalidades de autorización solos tendrán finalidad del control de acceso, custodia y adecuado mantenimiento del material, y no con fines de censura.

En todo caso se deberán adoptar las medidas necesarias para resguardar el derecho a la intimidad de las víctimas de violencia sexual, y de las niñas, niños y adolescentes víctimas de los grupos armados al margen de la ley, y para no provocar más daños innecesarios a la víctima, los testigos, u otras personas, ni crear un peligro para su seguridad.
} 
prescriben", "Aniquilar la diferencia", y la serie sobre desaparición forzada, esta institución ha logrado dar a la sociedad colombiana en general, un panorama sobre la violencia sexual, los ataques dirigidos a la población LGTBI y otros temas especialmente atroces, los cuáles hasta entonces no habían sido especialmente documentados o publicitados o sobre los cuáles por su naturaleza, no se había propiciado un debate amplio al respecto.

En conclusión, la Ley 975 de 2005 o Ley de Justicia y Paz incluyó el derecho a la verdad desde sus diferentes perspectivas, sus dimensiones individual y colectiva y como elemento fundamental para la garantía de la reparación integral de las víctimas de los miembros y grupos desmovilizados. A partir de la entrada en rigor de la CNRR se creó el Grupo de Memoria Histórica en el año 2007, el cual fue el encargado de la elaboración del informe establecido en el artículo 51 que hace referencia a las razones para el surgimiento y evolución de los grupos armados y que hoy lleva el nombre de Informe General ¡Basta ya! Colombia: Memorias de Guerra y Dignidad.

Tras diez años de aplicación, la Ley de Justicia y Paz ha tenido muchas críticas, particularmente se le atribuyen problemáticas en torno a la celeridad y la efectividad de sus procedimientos. A 10 años de aplicación existen 15 sentencias en firme contra los principales jefes paramilitares y ha sido objeto de múltiples problemáticas, entre ellas, la gran dificultad para avanzar en las investigaciones, la imposibilidad de establecer los diferentes daños que se le causaron a las víctimas debido a que el procedimiento se desarrolla en el contexto de la justicia penal y el acceso a este escenario por parte de las víctimas procedentes de territorios alejados resulta muy precario, este contexo ha implicado igualmente un avance lento en cuanto al esclarecimiento de la verdad. Actualmente se introdujo una reforma estructural que pretende hacer más ágiles y efectivos los procedimientos, sin embargo, esta reforma (Ley 1592 de 2012) también ha sido objeto de diferentes críticas.

De particular importancia resultan los cambios que se realizaron en torno a la figura del denominado esclarecimiento de la verdad. El artículo 10 de la Ley 1592 de $2012^{55}$ reformó el artículo

${ }^{55}$ Artículo 10. Modifíquese el artículo 15 de la Ley 975 de 2005, el cual quedará así:

Artículo 15. Esclarecimiento de la verdad. Dentro del procedimiento que establece la siguiente Ley los servidores públicos dispondrán lo necesario para que se asegure el esclarecimiento de la verdad sobre el patrón de macro criminalidad en el accionar de los grupos armados organizados al margen de la ley y se pueda develar los contextos, las causas y los motivos del mismo. 
15 de la Ley de Justicia y Paz e incluyó los criterios de priorización y selección de casos, dos elementos que constituyen la nueva piedra angular del esclarecimiento de la verdad en el plano judicial, por cuanto se orientan al esclarecimiento del patrón de macrocriminalidad ${ }^{56}$ y la responsabilidad de los máximos responsables. Estos elementos tomados del desarrollo del derecho penal internacional facilitan los procesos de esclarecimiento de la verdad en conflictos armados de carácter interno, que como el colombiano se caracterizan por un muy amplio número de víctimas y a su vez un amplio numero de victimarios, proceso llamado por algunos autores como de victimización horizontal.

Finalmente esta reforma introdujo el artículo $56 \mathrm{~A}^{57}$, por medio del cual se estableció el deber judicial de memoria. Por medio de este artículo los Tribunales Superiores del Distrito Judicial adquieren un deber en relación con la reconstrucción de la memoria histórica; y se establecen mecanismos de interacción entre el Centro Nacional de Memoria Histórica, la Fiscalía General de la

La investigación se surtirá conforme a los criterios de priorización que determine el Fiscal General de la Nación en desarrollo del artículo $16^{a}$ de la presente ley. En todo caso se garantizará el derecho de defensa de los procesados y la participación efectiva de las víctimas.

La información que surja de los procesos de justicia y paz deberá ser tenida en cuenta en las investigaciones que busquen esclarecer las redes de apoyo y financiación de los grupos armados organizados al margen de la ley.

56 El concepto Patrón de Criminalidad en el sistema de Justicia y Paz tiene fundamento legal en la Ley 1592 de 2012 que reformó la ley 975 de 2005, así como en el decreto reglamentario 2011 de 2013. Precisamente el artículo 16 de este decreto reglamentario de la ley 1592, establece, Definición de Patrón de Criminalidad: Es el conjunto de actividades criminales, prácticas y modos de actuación criminal que se desarrollan de manera repetida en un determinado territorio y durante un periodo de tiempo determinado, de los cuales se puede deducir los elementos esenciales de las políticas y planes implementados por el grupo armado organizado al margen de la ley responsable de los mismos. La identificación del patrón de macro criminalidad permite concentrar los esfuerzos de investigación en los máximos responsables del desarrollo o realización de un plan criminal y contribuye a develar la estructura y modus operandi del grupo armado organizado al margen de la ley, así como las relaciones que hicieron posible su operación.

${ }^{57}$ Artículo 56A. Deber judicial de memoria. Los Tribunales Superiores de Distrito Judicial, a través de la correspondiente secretaría, deberán organizar, sistematizar y conservar los archivos de los hechos y circunstancias relacionados con las conductas de las personas objeto de cualquiera de las medidas de que trata la presente ley, con el fin de garantizar los derechos de las víctimas a la verdad y preservar la memoria judicial.

También deberán garantizar el acceso público a los registros de casos ejecutoriados y disponer de los medios necesarios para divulgar la verdad de lo acontecido, en coordinación con el Centro de Memoria Histórica.

Los Tribunales Superiores de Distrito Judicial, a través de la correspondiente secretaría, deberán remitir copias de estos registros al Centro de Memoria Histórica.

En virtud del artículo 144 de la Ley 1448 de 2011, los Tribunales Superiores de Distrito Judicial podrán, a fin de fortalecer la construcción de la memoria histórica, encomendar la custodia de los archivos a los que se refiere el presente artículo al Archivo General de la Nación o a los Archivos de los entes territoriales.

La Fiscalía General de la Nación y el Centro de Memoria Histórica celebrarán convenios con el fin de regular el flujo de información para la construcción de la memoria histórica.

En desarrollo de estos convenios el Centro de Memoria Histórica podrá acceder a información reservada, sin que ésta pierda tal carácter. 
Nación y los Tribunales con el fin de preservar los archivos y articular acciones que contribuyan al deber de memoria del Estado.

La verdad histórica que se ha venido construyendo a partir del marco legal de Justicia y Paz, ha demostrado múltiples limitaciones que son producto de su desarrollo en el escenario eminentemente judicial, aunque las versiones libres permitieron un encuentro entre la víctima y su victimario, el mecanismo puramente adversarial del proceso penal, no permite la construcción de relatos amplios que aporten a la generación de verdades con carácter histórico, las verdades judiciales producto del escenario de justicia y paz, aunque de suma importancia para la comprensión del fenómeno macrocriminal, solamente incluyen la voz de victimarios, víctimas y testigos, lo cual redunda en la producción de verdades parciales y en blanco y negro.

De lo anterior se desprende que, si bien la incorporación del derecho a la verdad en la ley 975 se hizo partiendo de una verdad judicial, responde en primera medida a la inquietud planteada en contextos de transición, que no permiten la investigación de todas y cada una de las violaciones a los derechos humanos cometidas, sino que se basa en la selección de casos emblemáticos y ofrece incentivos a los perpetradores por sus contribuciones a la búsqueda de la verdad.

Por otra parte este contexto constituye un amplio cúmulo de aprendizajes que van a servir a la implementación de nuevos mecanismos de reconstrucción y búsqueda de la verdad. Es claro, que el escenario de Justicia y Paz, y particularmente los contenidos de las 46 sentencias existentes, ${ }^{58}$ otorgan importantes elementos frente a los patrones de macrocriminalidad de los grupos paramilitares, sin embargo, el reto que se nos plantea es bastante más difícil en materia de construcción de la verdad, pues incluye la pregunta sobre los patrones de macrocriminalidad de la violencia estatal y los crímenes de Estado.

58 Información a 25.10. 2016, tomada de la página de la Fiscalía General de la Nación. http://www.fiscalia.gov.co/jyp/direccion-de-fiscalia-nacional-especializada-de-justicia-transicional/ley_justicia_y_paz/ 


\subsection{Ley 1448 de 2011 o Ley de Víctimas y Restitución de Tierras}

Con el fin de ampliar los mecanismos de justicia transicional y consolidar mas instrumentos para lograr la garantía de los derechos a la verdad, la justicia y la reparación de las víctimas, el presidente Juan Manuel Santos sancionó la Ley 1448 de 2011 o Ley de Víctimas y Restitución de Tierras, mecanismo de justicia transicional de carácter administrativo que, junto a la Ley de Justicia y Paz y particularmente frente a la reforma introducida por la Ley 1592 de 2012, vino a completar el marco jurídico de justicia transicional aplicable en Colombia para la desmovilización y reinserción de miembros de grupos armados organizados al margen de la ley, y la reparación, asistencia y atención a las víctimas de graves violaciones a los Derechos Humanos.

El objeto de la Ley es establecer un conjunto de medidas judiciales, administrativas, sociales y económicas, individuales y colectivas, en beneficio de las víctimas que individual o colectivamente hayan sufrido un daño por hechos ocurridos a partir del $1^{\circ}$ de enero de 1985 como consecuencia de infracciones al DIH o de violaciones graves y manifiestas a las normas internacionales de Derechos Humanos, ocurridas con ocasión del conflicto armado interno, dentro de un marco de justicia transicional, que posibiliten hacer efectivo el goce de sus derechos a la verdad, la justicia y la reparación con garantía de no repetición, de modo que se reconozca su condición de víctimas y se dignifique a través de la materialización de sus derechos constitucionales.

Es necesario aclarar que si bien la ley establece el 1 de enero de 1985 como fecha límite frente a las medidas de atención y reparación establecidas en la ley, en lo que atañe a las medidas de reparación simbólica, las garantías de no repetición y en relación con el derecho a la verdad, la ley establece el derecho a este tipo de medidas de las personas que hayan sido víctimas de hechos ocurridos antes de esa fecha, como parte de un conglomerado social y sin necesidad de que sean individualizadas.

El derecho a la verdad se introduce como principio orientador del marco jurídico establecido. A través del artículo $23^{59}$ de la Ley, se reconoce que es un derecho y un principio general de la

\footnotetext{
${ }^{59}$ Artículo 23. Derecho a la verdad. Las víctimas, sus familiares y la sociedad en general, tienen el derecho imprescriptible e inalienable a conocer la verdad acerca de los motivos y las circunstancias en que se cometieron las violaciones de que trata el artículo $3^{\circ}$ de la presente ley, y en caso de fallecimiento o desaparición, acerca de la suerte que corrió la víctima,
} 
reparación integral, establece y reconoce su imprescriptibilidad y su carácter inalienable, y otorga un lugar central a su dimensión colectiva cuando manifiesta el derecho a la verdad de la sociedad en general. Frente al carácter individual, se refiere al esclarecimiento de los motivos y las circunstancias en que se cometieron las violaciones, hace referencia al deber de informar sobre el paradero de las personas desaparecidas y se refiere al derecho a la verdad que se materializa en el derecho a saber y en el derecho a la información.

La Ley está estructurada a partir de los diferentes componentes que integran el concepto de reparación integral, su estructura interna divide por capítulos las diferentes normas que desarrollan los componentes de restitución, indemnización, rehabilitación, garantías de no repetición y las medidas de satisfacción y reparación simbólica. Debido al reconocimiento por parte del Estado de las situaciones precarias en las que se encontraban las víctimas, inclusive antes de sufrir una violación grave de sus Derechos Humanos fundamentales, se incluyó como principio orientador el concepto de la reparación con enfoque transformador, y una serie de medidas orientadas a atender y brindar asistencia a las víctimas con el fin de restablecer la vigencia efectiva de derechos fundamentales constitucionales mientras se avanza en la reparación integral por daños producto de las diferentes violaciones a sus Derechos Humanos.

Es de anotar que el derecho a la verdad tiene dos connotaciones, por una parte se trata de un derecho que se ha constituido progresivamente a partir de los diferentes instrumentos de Derechos Humanos y cuyo núcleo duro se encuentra en los instrumentos que hacen parte del Derecho Internacional de los Derechos Humanos y que encuentra su fundamento legal en los fines del Estado de derecho y la consolidación de un Estado democrático. Es por tanto, una condición fundamental para la consolidación del Estado de Derecho garantizar el derecho inalienable a la verdad de la sociedad. Por otra parte, el derecho a la verdad se encuentra inmerso en la obligación del Estado de reparar los daños ocasionados por la comisión de graves violaciones a los Derechos Humanos

y al esclarecimiento de su paradero. La Fiscalía General de la Nación y los organismos de policía judicial deberán garantizar el derecho a la búsqueda de las víctimas mientras no sean halladas vivas o muertas.

El Estado debe garantizar el derecho y acceso a la información por parte de la víctima, sus representantes y abogados con el objeto de posibilitar la materialización de sus derechos, en el marco de las normas que establecen reserva legal y el manejo de información confidencial. 
cometidos tanto por agentes estatales como no estatales, y encuentra su fundamento en la obligación general internacional de reparar el daño a las víctimas.

Las medidas de satisfacción fueron incluidas tal y como se mencionó anteriormente en los principios y directrices básicos sobre el derecho de las víctimas de violaciones manifiestas de las normas internacionales de Derechos Humanos y de violaciones graves del DIH a interponer recursos y obtener reparaciones. Este instrumento recogió en el año 2005 los diferentes estudios que se habían hecho en torno al derecho a la verdad, la justicia y la reparación y agrupó cada uno de estos derechos en un tipo de medida específica con el fin de otorgar mecanismos para que los Estados los implementen en sus procedimientos internos. La Ley 1448 de 2011 optó por incluir las medidas de satisfacción y en ellas incluyó acciones de diferente tipo, entre las cuales incluyó las acciones orientadas a la reconstrucción de la memoria histórica.

Las medidas de satisfacción son definidas en el artículo 139 de la Ley en mención como aquellas acciones tendientes a restablecer la dignidad de la víctima y difundir la verdad sobre lo sucedido, proporcionan bienestar y contribuyen a mitigar el dolor de la víctima. Estas medidas aportan a la garantía del derecho a la verdad a partir de diferentes acciones como el reconocimiento público del carácter de víctima, la realización de actos con carácter conmemorativo y la difusión pública del relato de las víctimas sobre sus procesos de victimización entre otras.

El artículo 143 de la Ley de Víctimas y Restitución de Tierras establece el deber de memoria del Estado, el cual

[S]e traduce en propiciar las garantías y condiciones necesarias para que la sociedad, a través de sus diferentes expresiones tales como víctimas, academia, centros de pensamiento, organizaciones sociales, organizaciones de víctimas y de Derechos Humanos, así como los organismos del Estado que cuenten con competencia, autonomía y recursos, puedan avanzar en ejercicios de reconstrucción de memoria como aporte a la realización del derecho a la verdad del que son titulares las víctimas y la sociedad en su conjunto.

En un parágrafo del artículo se estipula que:

[E]n ningún caso las instituciones del Estado podrán impulsar o promover ejercicios orientados a la construcción de una historia o verdad oficial que niegue, vulnere 0 
restrinja los principios constitucionales de pluralidad, participación y solidaridad y los derechos de libertad de expresión y pensamiento. Se respetará también la prohibición de censura consagrada en la Carta Política.

En este marco, con miras al cumplimiento de las obligaciones derivadas del derecho a la verdad y la garantía del deber de memoria por parte del Estado en favor de las víctimas y de la sociedad en general, la Ley 1448 de 2011 creó el Centro Nacional de Memoria Histórica -CNMH, el cual tiene por objeto reunir, recuperar y acopiar todo el material documental, testimonios orales y de cualquier medio sobre las violaciones graves a los Derechos Humanos y al Derecho Internacional Humanitario, así como contribuir mediante sus investigaciones a la reconstrucción de la memoria histórica y al esclarecimiento de la verdad. EI CNMH ha venido realizando una importante labor a partir de las investigaciones basadas en casos emblemáticos ${ }^{60} \mathrm{e}$ informes temáticos ${ }^{61}$, el apoyo a la construcción de memoria desde diferentes contextos sociales y comunitarios, la construcción de una política pública de archivos y la conceptualización y avance sobre los retos en cuanto a la construcción social de una memoria colectiva y del Museo Nacional de la Memoria Histórica. Los aportes al derecho a la verdad desde esta perspectiva, son claves pues representan la voz de las víctimas y contribuyen a la comprensión de los diferentes contextos locales y nacionales, los repertorios de violencia, modalidades de victimización, daños y afectaciones causados a la población civil, constituyen elementos para la comprensión de la violencia como fenómeno estructural de la sociedad colombiana y Latinoamericana.

En el año 2013 el CNMH publicó el informe general "Basta Ya Colombia!: memorias de guerra y dignidad", el informe da cumplimiento al mandato legal establecido en la Ley 975 de 2005, o Ley de Justicia y Paz, de elaborar un relato sobre el origen y la evolución de los actores armados ilegales. En su desarrollo, el GMH, adscrito primero a la CNRR, y cuyo legado fue asumido por el CNMH, se propuso dar respuesta a este requerimiento desde la consideración de los actores armados ilegales,

${ }^{60}$ El CNMH define el caso emblemático como lugares de condensación de procesos múltiples que se distinguen no solo por la naturaleza de los hechos, sino también por su fuerza explicativa.

${ }^{61}$ Algunos de los estudios temáticos más importantes son: I) Justicia y Paz ¿verdad judicial o verdad histórica?, II) política de reforma agraria y tierras en Colombia, III) resistencia en el cauca indígena, iv) guerrilla y población civil, v) tres informes especiales sobre las dimensiones del desaparición forzada en Colombia. 
no solo como aparatos de guerra, sino, especialmente, como productos sociales y políticos del devenir de nuestra configuración histórica como país ${ }^{62}$. El informe generó importantes aportes al derecho a la verdad, particularmente su contenido otorga elementos para el esclarecimiento de hechos relacionados con actores armados involucrados, las diferentes modalidades de violencia, victimas, grupos y sectores sociales victimizados, la actuación del Estado en estos contextos, el papel de la justicia y los contextos tanto locales como nacionales.

Al igual que ocurre con la ley de Justicia y Paz, los aportes del CNMH son contundentes en cuanto a la actuación de los grupos paramilitares, sin embargo nuevamente el reto se centra en los crímenes de Estado, así como en la violencia ejercida por los diferentes grupos guerrilleros, cuestión sobre la cual existen muchos vacíos que se deberán ir llenando en la medida en que se avance en mecanismos de construcción de la verdad.

No obstante lo anterior, no puede desconocerse el avance que en materia de esclarecimiento a la verdad y acceso a la justicia se ha hecho, no sólo a través de la implementación de la ley 975 sino además, a través del reconocimiento que del derecho a la verdad se ha hecho en la ley 1448 como elemento fundamental dentro de la reparación a las víctimas, dado el carácter dignificador de la misma a pesar de sus limitaciones.

\subsection{Ley 1424 de 2010 - El Mecanismo no Judicial de Contribución a la Verdad y la Dirección de Acuerdos de la Verdad}

El mecanismo no judicial de contribución a la verdad de la Ley 1424 de 2010 surgió ante el llamado limbo jurídico que se presentó con aproximadamente 19.000 paramilitares durante el proceso de desmovilización llevado a cabo por el primer gobierno de Álvaro Uribe Vélez. Para entender el limbo, y por tanto el surgimiento del mecanismo no judicial de contribución a la verdad, es necesario remontarnos a los orígenes de las diferentes leyes orientadas a facilitar la consecución de diálogos de paz y la desmovilización y reinserción de combatientes.

62 GMH ¡BASTA YA! Colombia: Memorias de guerra y dignidad. Bogotá: Imprenta Nacional, 2013. 
Tal como se mencionó al inicio de este capítulo, el Gobierno Nacional inició una producción legislativa orientada a establecer mecanismos jurídicos que facilitaran la desmovilización y reincorporación a la vida civil de combatientes, así como facilitar acuerdos humanitarios. Fue así como se aprobó la Ley 418 de 1997 que fue progresivamente prorrogada en su vigencia por otras normas ${ }^{63}$, hasta llegar a la Ley 975 de 2005 la cual incluyó, como se dijo arriba, un marco jurídico de justicia transicional diferente al modelo tradicionalmente utilizado, basado únicamente en procesos de desarme, desmovilización y reinserción (DDR), sin atender fines como la paz, la reconciliación y la reparación a las víctimas.

Estas leyes establecían la posibilidad de conceder los beneficios de amnistía impropia ${ }^{64} \mathrm{e}$ indulto a las personas que hubieren incurrido en delitos políticos y conexos. En aplicación de estas disposiciones, aproximadamente 12.000 personas desmovilizadas de grupos paramilitares fueron beneficiadas con amnistías impropias, a través de la expedición de resoluciones inhibitorias ${ }^{65}$ en investigaciones preliminares adelantadas por el delito de sedición.

La calificación de los paramilitares como delincuentes políticos generó amplias discusiones en el país, al cuestionarse la validez de aplicar el tipo penal de sedición, razón por la cual, se incluyó en el artículo 71 de la Ley 975 de 2005 una adición al artículo 468 del Código Penal que regula el delito de sedición, estableciendo que incurrían también en esta conducta ilícita "quienes conformen 0 hagan parte de grupos guerrilleros o de autodefensa cuyo accionar interfiera con el normal funcionamiento del orden constitucional y legal". Este artículo fue declarado inexequible por la Corte Constitucional mediante Sentencia C-370 de 2006, por vicios de procedimiento en su formación.

Sin embargo, este artículo estuvo vigente desde el momento en que la Ley 975 se publicó en el diario oficial (25 de julio de 2005) hasta la fecha en que se profirió el citado fallo por parte de la Corte Constitucional (18 de mayo de 2006), circunstancia que permitió que la Sala Penal de la Corte

\footnotetext{
63 La Ley 418 de 1997 fue prorrogada en su vigencia y modificada en algunos de sus contenidos por las leyes 548 de 1999 , 782 de 2002, 1106 de 2006 y 1421 de 2010.

64 La amnistía puede ser propia o impropia. Propia, cuando sus beneficios cobijan a personas sindicadas que estén siendo investigadas o juzgados por delitos políticos, caso en el cual el fiscal o juez ordena la cesación de todo procedimiento. Se considerará impropia, cuando sobre los delincuentes políticos respecto de los cuales ya se ha dictado sentencia condenatoria, procede el juez que dictó la sentencia de primera instancia, a hacer cesar la ejecución de la pena.

${ }^{65} \mathrm{La}$ resolución inhibitoria consiste en un acto administrativo de carácter procesal por medio del cual el fiscal, decide abstenerse de iniciar la acción penal en contra de un sindicado.
} 
Suprema de Justicia concluyera la validez de su aplicación, aduciendo el principio de favorabilidad, según los siguientes argumentos:

Lo consignado hasta aquí conduce a predicar de manera categórica - tal como ya se había adelantado que la inexequibilidad del artículo 71 de la Ley 975 de 2005 declarada mediante la sentencia C-370 de mayo 18 de 2006 sólo produce efectos hacia el futuro, lo que comporta afirmar que todas aquellas conductas que fueron cometidas antes de la reseñada fecha I) constitutivas para entonces de concierto para delinquir con fines de organizar, promover, armar o financiar grupos armados al margen de la ley, siempre y cuando su accionar interfiera con el normal funcionamiento del orden constitucional y legal, o II) por quienes hayan conformado 0 hagan parte de grupos guerrilleros con similar accionar de interferencia, deberán ser tipificadas como sedición, a términos del precitado artículo 71 , dado que tal calificación comporta efectos favorables para el sindicado o condenado. (Corte Suprema de Justicia, 8 ago. 2006)

Como consecuencia de la declaratoria de inconstitucionalidad de la disposición que permitía la calificación de sediciosos para las personas desmovilizadas de grupos paramilitares, el Gobierno Nacional expidió el Decreto 4436 de 2006, reglamentario de la Ley 782 de 2002 (que prorrogó la ley 418 de 1997), con el fin de establecer parámetros para el otorgamiento de beneficios jurídicos (amnistía impropia e indulto) a las personas desmovilizadas procedentes de tales grupos, que con anterioridad a la Sentencia C-370 de 2006 hubieren incurrido en conductas relativas a su conformación e integración, consideradas como delito de sedición por la autoridad judicial competente.

Sin embargo, la Corte Suprema de Justicia en la sentencia proferida por los Magistrados Yesid Ramírez y Julio Enrique Socha, el 11 de julio de 2007, dentro del proceso de radicado $\mathrm{N}^{\circ} 26945$, concluyó que se hacía inoperante este decreto, al establecer que la conducta de los paramilitares no constituía delito político y, en consecuencia, estos no pueden ser beneficiarios de amnistía ni indulto, no podrán acceder al servicio público y de hacerlo estarían incursos en causal de pérdida de investidura y por tanto su actuar lo incluyó dentro del tipo penal de concierto para delinquir agravado.

Esta sentencia generó el denominado "limbo jurídico", el cual hace referencia a la inseguridad jurídica en la cual se encontraban los paramilitares desmovilizados, que era necesario resolver con el 
fin de garantizar la reintegración a la vida civil, si no estaban incursos en graves delitos, situación que les exigía postularse a la Ley 975 de 2005.

Así las cosas, surgió la Ley 1312 de 2009, a través de la cual se incluyó el numeral 17 del artículo 324 de la Ley 906 de 200466, disposición relativa al principio de oportunidad. Esta norma habilitaba la aplicación de este principio a favor de las personas desmovilizadas comprometidas con la reintegración a la vida civil que no tuvieran en su contra investigaciones por delitos cometidos antes o después de su desmovilización, con excepción de los relativos a la pertenencia al respectivo grupo paramilitar. Pero este instrumento jurídico fue declarado inexequible por la Corte Constitucional, en la sentencia C-936 de 2010, al sustentar que no garantizaba el derecho de las víctimas a la verdad, la justicia y la reparación, entre otras razones, lo cual conllevó a la expedición de la Ley 1424 de 2010 (CNMH, 2014)

En consecuencia, la Ley 1424 fue definida con el objetivo de contribuir al logro de la paz, la satisfacción de las garantías de verdad, justicia y reparación de las víctimas. Igualmente, se establece en el marco de los instrumentos de jurídicos de justicia transicional y por tanto contribuye al logro de la paz y la no repetición de los hechos de violencia.

Este instrumento jurídico estableció los parámetros para que las personas desmovilizadas de grupos paramilitares que hubiesen incurrido únicamente en determinados delitos ${ }^{67}$, como consecuencia de su pertenencia a estos grupos, "pudieran acceder a los beneficios jurídicos de suspensión de las órdenes de captura o la no imposición de medida de aseguramiento y la suspensión condicional de la ejecución de la pena, atendiendo al estado del proceso penal adelantado" (CNMH, 2014, p.57). De esta manera nace a la vida jurídica y del contexto de la justicia transicional colombiana los mecanismos no judiciales de contribución a la verdad, en cuanto que para que las personas desmovilizadas logren acceder a los beneficios de la ley 1424 deben en primer lugar suscribir el instrumento denominado acuerdo de contribución a la verdad y la memoria histórica. El CNMH en el marco del Decreto 2244 de 2011 a través de la Dirección de Acuerdos de la Verdad tiene la función de recolectar, clasificar, sistematizar, analizar y preservar la información que surja de los Acuerdos de

66 Ley 906 de 2004, por medio de la cual se expide el código de procedimiento penal.

${ }^{67}$ Delitos de concierto para delinquir simple o agravado, utilización ilegal de uniformes e insignias, utilización ilícita de equipos transmisores o receptores, y porte ilegal de armas de fuego o municiones de uso privativo de las Fuerzas Armadas o de defensa personal. Artículo 1, Ley 1424 de 2010. 
Contribución a la Verdad Histórica y la Reparación de que trata la Ley 1424 de 2010, así como de la información que se reciba, de forma individual y colectiva, de los desmovilizados con quienes se haya suscrito el Acuerdo de Contribución a la Verdad Histórica y la Reparación y de aquellas personas que voluntariamente deseen hacer manifestaciones sobre asuntos que guarden relación o sean de interés para el mecanismo no judicial de contribución a la verdad y la memoria histórica.

Este mecanismo es concebido como un proceso de memoria histórica y se concibe como medida de satisfacción para las víctimas del conflicto armado colombiano. Está relacionado con figuras de carácter internacional, tales como las comisiones de la verdad o las comisiones de investigación. Su evaluación constitucional y aprobación por parte de la Sentencia C-771 de 2011 se basa en tres presupuestos a los cuales debe atender este mecanismo:

$\checkmark$ Contribuir efectivamente al esclarecimiento de la conformación de los grupos paramilitares al que pertenecían.

$\checkmark$ Contribuir frente al esclarecimiento del contexto general de su participación

$\checkmark Y$ poner de presente todos los hechos o actuaciones de que tengan conocimiento en razón de su pertenencia, como garantía al derecho a saber de la sociedad.

El mecanismo de contribución a la verdad, ha venido generando importantes resultados en relación al esclarecimiento de los contextos en los cuales surgieron y operaron las diferentes estructuras paramilitares a lo largo y ancho del país. La ley 1424 tiene el título de ser la ley más rápida tramitada en el Congreso de la Republica y demostró, la inseguridad jurídica subyacente al mecanismo establecido en la Ley 975 de 2005. Esta cuestión resulta de vital importancia en perspectiva de nuevos mecanismos que se implementen en un eventual proceso de acuerdo de terminación del conflicto, pues deben ser muy bien planificados y deben brindar la suficiente seguridad jurídica para generar la confianza necesaria frente a los procesos de DDR que se quieren implementar con los grupos armados que aun continúan desplegando acciones armadas sobre los territorios. 


\section{CONCLUSIONES Y RECOMENDACIONES.}

Al realizar el abordaje al derecho a la verdad, a partir del enfoque dogmático teórico, surgen múltiples problemáticas que están relacionadas con las propias tensiones, que subyacen del discurso de los derechos humanos y que por tanto deben tenerse en cuenta al analizar cuestiones como la estructura fundamental, el nivel de juridicidad o la naturaleza jurídica del derecho a la verdad. La tensión entre la razón de Estado y la razón de los derechos, planteada por Boaventura de Souza Santos, permite entender de una forma más holística las problemáticas frente a la efectividad del derecho a la verdad, o como lo denominan algunas investigaciones, el nivel de juridicidad del derecho a la verdad. Esta tensión se trata: "de un vasto campo de tensiones que enfrenta las creencias con los intereses políticos, el derecho internacional con el nacional, los pactos políticos y las luchas sociales, y la normalidad democrática con el Estado de emergencia. Es el reconocimiento o no de las violaciones masivas de los derechos humanos - masacres, asesinatos, torturas, desapariciones, confiscaciones, homicidios en general, crímenes contra la humanidad - cometidas por Estados de excepción, potencias coloniales o regímenes dictatoriales. Este es el campo del derecho a la verdad y la memoria, de las comisiones de la verdad y reconciliación, es un campo de confrontación política en muchas partes del mundo y tiene en el continente latinoamericano el caso específico de los crímenes cometidos por las dictaduras militares de la década de los setenta" (De Sousa, 2014, p.49).

A nivel internacional, el derecho a la verdad se desarrolló de manera paulatina, hoy existe un cuerpo normativo internacional amplio frente a su composición, importancia y elementos esenciales. Su desarrollo está determinado por la necesidad de combatir el fenómeno de la impunidad, particularmente por la inacción de los Estados desde la óptica de garante de los derechos humanos de la población, así como por la participación directa de los Gobiernos en la comisión de graves violaciones a los derechos humanos, crímenes de lesa humanidad e infracciones al $\mathrm{DIH}$.

La evolución del derecho penal internacional y la evolución conceptual y jurídica frente a crímenes de carácter internacional, ha incorporado nuevos estándares frente a la garantía y efectividad del derecho a la verdad, particularmente respecto al deber reforzado de los Estados en la búsqueda de la verdad cuando se trata de conflictos de carácter interno, donde se han cometido sistemática y 
generalizadamente crímenes de lesa humanidad, infracciones al DIH y graves violaciones a los derechos humanos.

La justicia transicional como modelo de justicia para afrontar un pasado problemático, caracterizado por violaciones graves a los derechos humanos, crímenes de lesa humanidad e infracciones al $\mathrm{DIH}$, ha contribuido a la producción de verdad. Los diferentes mecanismos implementados en Colombia, de carácter judicial y administrativo, han aportado a la generación de un contexto amplio de producción de verdad, al cual le aportan en mayor o menor medida diferentes sectores de la sociedad.

En el contexto de la justicia transicional, el derecho a la verdad, tiene diferentes componentes, el esclarecimiento de hechos ocupa un lugar privilegiado, y su garantía regula las relaciones entre la producción de verdad judicial y la verdad histórica, y por tanto está relacionado con la posibilidad de construir un relato social desde la perspectiva de memoria que contribuya a la comprensión de la violencia y por tanto a la no repetición (Uprimy, 2006, p.345),

En Colombia a partir de la implementación de instrumentos de justicia transicional, se desarrolló un cuerpo jurídico sólido, que incorporó vía bloque de constitucionalidad, estándares duros frente al deber de garantizar y hacer efectivo el derecho a la verdad. Sin embargo al momento de su aplicación efectiva, las tensiones inherentes a la justicia con carácter transicional sometidas a debates políticos tornan inocua y preocupante su plena efectividad. Las demandas de las víctimas de ejecuciones extrajudiciales, desaparición forzada o violencia sexual, frente a la inactividad del aparato judicial y frente a la ausencia de esclarecimiento y de responsabilidades es un ejemplo de lo planteado.

Frente al derecho a la verdad, el legislador colombiano optó por desarrollar un contenido que en la Ley de Justicia y Paz podríamos denominarlo como de verdad judicial, el cual profundiza más en el aspecto individual y está mucho más determinado por los objetivos que son resorte del denominado recurso judicial efectivo, en cuanto incluye elementos que responsabilizan y está fundamentado en un proceso de carácter judicial. A pesar de que son pocos los pronunciamientos frente a la sistematicidad y generalidad en la cual han ocurrido las violaciones, su contenido en materia de derecho a la verdad es clave en cuanto establece la naturaleza jurídica internacional de los crímenes. Por otra parte en todas las sentencias de justicia y paz se nota un profundo interes por contribuir a lo que la regla 
constitucional llamó " la posibilidad de elaborar un relato colectivo relativamente fidedigno sobre los hechos".

Sin perjuicio de lo anterior es necesario puntualizar en que, si bien la ley 975 sienta un precedente en cuanto a la incorporación del derecho a la verdad en contexto transicional, a raíz del marco incompleto en que este derecho es abordado en la ley, se presenta una contingencia en la que es necesario desbordar la verdad desde lo judicial, y se incorporan elementos de reconstrucción de la verdad desde la memoria histórica, ampliando el alcance de la configuración de una verdad más amplia, construida desde la comunidad, y que incorporó diversos elementos que van más allá de los elementos del esclarecimiento incluyendo cuestiones de carácter psicosocial y comunitario, que en el marco del esclarecimiento no son tenidos en cuenta.

El CNMH se encuentra inmerso en un mecanismo de carácter administrativo y se establece como instrumento para hacer efectivas medidas orientadas a la satisfacción de las víctimas. Su naturaleza jurídica, obedece al cumplimiento de los instrumentos internacionales relacionados con la reparación integral a víctimas y particularmente es la incorporación de los procedimientos establecidos en los principios y directrices básicos sobre el derecho de las víctimas de violaciones manifiestas de las normas internacionales de Derechos Humanos y de violaciones graves del Derecho Internacional Humanitario a interponer recursos y obtener reparaciones, en particular es la aplicación en Colombia del deber de memoria de los Estados.

La contribución del CNMH es de carácter invaluable, los diversos informes dan cuenta de temáticas claves para la comprensión social del conflicto colombiano y van más allá, permitiendo además comprender socialemente la violencia como fenómeno latinoamericano y mundial. Estos informes constituyen el patrimonio histórico de las sociedades que se han visto sometidas a niveles de violencia inimaginables, que sobrepasan la comprensión de sus víctimas.

Las medidas de satisfacción en perspectiva de reconstrucción de la memoria histórica, no constituyen per se la garantía completa del derecho a la verdad, menos si como en el caso colombiano se implementan en medio del conflicto armado y sin un acuerdo de terminación del mismo. Sin embargo, constituyen un reconocimiento de la dignidad de las víctimas que debe acompañarse desde el plano judicial por la verdad judicial, que brinda los elementos para que la memoria histórica sirva como elemento fundamental para la prevención de la impunidad y la repetición de las violaciones a 
partir de elementos de esclarecimiento sobre las causas, modos y responsabilidades que apoyen la construcción de un relato colectivo sobre el pasado violento.

Por medio de la reforma introducida a la Ley 975 de 2005 a través de la Ley 1592, y particularmente en desarrollo del artículo 56A, se introdujo un mecanismo de complementariedad entre el mecanismo judicial de carácter penal y el mecanismo administrativo, pues crea un instrumento para que la verdad judicial sea a su vez verdad histórica. Dicho artículo, denominado "deber judicial de memoria" obliga a la articulación entre los Tribunales de Justicia y Paz y el CNMH.

Los instrumentos internacionales de Derechos Humanos citados y analizados, consagran una cláusula de libertad de apreciación para los estados, en razón a esto, son los mismos estados los que deben organizar su jurisdicción interna para satisfacer entre otros, el derecho a la verdad, creando diferentes mecanismos tanto de tipo judicial como administrativo. En Colombia este derecho se encuentra establecido tanto en el ámbito judicial como administrativo y en virtud de esto, su efectividad está relacionada con los niveles de complementariedad e integralidad que se logren.

El país debe avanzar en la implementación de una política pública integral de verdad y memoria, que permita el avance frente al punto de esclarecimiento de hechos, aceptación de responsabilidades y a su vez impulse una cultura de la memoria histórica, con el respaldo de una estructura institucional que proyecte la construcción de un relato colectivo, a largo plazo, que integre las miradas y relatos de las regiones más apartadas que aun hoy día no interpelan con los escenarios públicos y privados urbanos.

A través de los procesos adelantados en el marco de la ley de justicia y paz, se ha conseguido establecer un gran adelanto frente al esclarecimiento de hechos criminales cometidos por grupos paramilitares, las pocas sentencias que existen tienen un gran valor en materia de verdad judicial, que junto a las investigaciones del CNMH contribuyen a la construcción de un relato colectivo. Sin embargo aún no hay adelantos contundentes frente al esclarecimiento de crímenes de Estado, ejecuciones extrajudiciales, violencia sexual y asesinatos, e igualmente no hay avances frente al esclarecimiento de hechos cometidos por los grupos guerrilleros, de manera que es aún un camino que hace falta recorrer para avanzar en la producción de verdad jurídica e histórica.

De la misma manera, el marco jurídico existente plantea la obligación del Estado de investigar los crímenes y garantizar el esclarecimiento de los motivos y las circunstancias en que se cometieron 
las violaciones, uno de los elementos que se han dejado por fuera en la ley, es la responsabilidad de quienes participaron en estas conductas más allá de la autoría material. Tanto las investigaciones de la fiscalía como las herramientas de reconstrucción de la memoria histórica puestas en marcha por las diferentes instituciones dispuestas para tal fin, han logrado grandes avances en materia del esclarecimiento de patrones de macro criminalidad, respondiendo a algunas de las demandas en materia de reparación a las víctimas. Sin embargo, las capacidades del ente investigador no son suficientes para esclarecer los nexos de actores fuera del conflicto armado con los crímenes cometidos, razón por la cual resulta indispensable potencializar el alcance de los mecanismos extrajudiciales para el esclarecimiento de la verdad más allá de la comisión del hecho y mucho más orientado a el esclarecimiento de las relaciones económicas, políticas

El reto entonces, más allá de incorporar los elementos principales del derecho a la verdad dentro de la legislación doméstica, radica entonces en generar un debate público sobre estos temas, el cual involucre a distintos actores de la sociedad. Dicho debate, si bien no atenta contra los derechos de las víctimas y debe estar orientado a no generar nuevas victimizaciones, debe llevar a un reconocimiento como sociedad y una toma de responsabilidad que permita potenciar el carácter reparador de la verdad.

La fiscalía ha ido avanzando en materia de esclarecimiento de la verdad, la incoporación de nuevos mecanismos de imputación, desarrollados en el marco del derecho penal internacional como forma para afrontar los crímenes internacionales ha revolucionado la investigación. La adolescente unidad de contexto, aunque lentamente, ha ido avanzando hacia nuevas formas de comprensión de la macro criminalidad, estos nuevos paradigmas parecen compadecerse más con la compleja realidad que se pretende afrontar.

Tal y como quedó establecido en esta investigación, en procesos de negociación, de paz y de reconciliación, los archivos toman una importancia estructural y por consiguiente el derecho a la información es piedra angular frente a los procesos de búsqueda de la verdad. En Colombia, se viene construyendo una política pública de archivos y existe igualmente una política pública de transparencia, sin embargo es muy preocupante el panorama frente a los archivos de inteligencia y contrainteligencia que están en manos de la fuerza pública, ejercito y policía, pues aun la gran cantidad 
de archivos referentes a operaciones del ejército y la policía violatorias de derechos humanos y donde se han cometido crímenes de lesa humanidad en el marco de políticas de persecución a líderes de oposición, izquierda y comunidades y periodistas, se mantiene bajo reserva legal. En esta misma perspectiva es muy preocupante la situación de abogados que litigan casos en los cuales se encuentran vinculados miembros de la fuerza pública, a la fecha de entrega de esta investigación la cifra de defensores de derechos humanos asesinados asciende a 36 , solo en 2015 , lo cual en perspectiva de negociaciones es muy preocupante.

Frente al complejo tema de la desaparición forzada en Colombia, el CNMH presentó la escalofriante cifra de 60.630 desaparecidos, "ni la suma de todas las dictaduras del cono sur se acerca a la desaparición en la democracia colombiana”, manifestó Gonzalo Sánchez quien dirige el CNMH. Esta cifra, plantea muchas preguntas en perspectiva de lo que significa la garantía y efectividad del derecho a la verdad. Este contexto es un desafio para el derecho internacional. Desde esta investigación mi recomendación y consideración frente a este puntual tema, es que no es posible dejar en manos de la justicia transicional de carácter nacional este complejo asunto de los desparecidos y sus familiares, aún atendiendo a la creación de un nuevo mecanismo en la implementación de los acuerdos entre el Gobierno y las FARC EP, se hace necesario que las víctimas de este grave crímen cuenten con una comisión de cáracter internacional y humanitario que haga presencia en Colombia y que ayude a los familiares de las personas desaparecidas a averguar por la suerte y el paradero de sus seres queridos, a su vez, que facilite el relacionamiento con los mecanismos institucionales creados para ello.

En materia de archivos, aunque los avances de la dirección de archivos del CNMH han sido destacados, elaborando y proponiendo una política pública de archivos, es preocupante la situación de los archivos de las fuerzas de seguirdad del Estado. Actualmente el trabajo del CNMH ha girado en torno a la identificación, conservación, organización, acopio y preservación de archivos de organizaciones defensoras de derechos humanos, organizaciones de víctimas y algunas instituciones. Sin embargo nada o muy poco se ha avanzado en relación con los archivos de las fuerzas de seguridad, Ejercito, Policía, DAS y demás organismos adscritos al Estado.

Frente los mecanismos de contribución a la verdad, y concretamente frente a lo establecido en el punto 5 de los diálogos de la Habana, correspondiente a la creación de una comisión para el esclarecimiento de la verdad, la convivencia y la no repetición, aunque no fue abordado en esta 
investigación por el contexto temporal, y por no ser objeto de nuestro estudio, es sin duda un avance más en la efectividad y garantía del derecho a la verdad. Lamentablemente 3 años es muy poco tiempo frente a la complejidad que presenta el conflicto armado colombiano.

Si este mecanismo es estructurado con la fuerza adecuada debe lograr el reconocimiento público de responsabilidades, y por tanto fomentar el debate que hasta ahora no se ha dado la sociedad colombiana. Una de las preguntas que en el marco de la implementación de este mecanismo se realizan es qué va a pasar con el CNMH. Desde esta investigación pensamos que el CNMH debe continuar sus trabajo tal y como lo viene realizando. La comisión de la verdad, es un mecanismo de un carácter mucho más político que jurídico. El CNMH debe continuar recopilando todo el material documental producto de sus investigaciones, con las cuales hace un verdadero aporte a la sociedad colombiana pues facilitan la comprensión social de la violencia de larga duración en Colombia desde una perspectiva plural, desde diferentes voces y visiones, y dando centralidad a las víctimas a través de la implementación de procesos de largo aliento, cuestiones que la Comisión por su naturaleza no logrará abordar.

El material documental del CNMH, sus investigaciones y las apuestas por la construcción de un museo nacional de la memoria histórica, así como los resultados de la dirección de acuerdos por la verdad, deberán dialogar con la Comisión de la Verdad, sin embargo el reto que afronta este mecanismo, por el mismo hecho de surgir de las posiblidades que brinda un acuerdo especial estará a merced de las tensiones políticas. Sin embargo, es posible que se logré el reconocimiento público de responsabilidades, que fomenté un debate que hasta ahora no ha dado la sociedad en su conjunto, reconociendo la crisis actual y permitiendo reconocer no solo lo que nos pasó como sociedad, sino además permitiendo la estructuración de medidas reales para la no repetición, generando las condiciones para la aplicación de un marco de justicia dirigido hacia la restauración de los lazos sociales rotos por las décadas de violencia, que hasta ahora sólo se han reparado de manera fragmentada 68 .

68 Dada la incipiente incorporación al sistema social colombiano, de la noción de justicia orientada a la restauración del tejido social y la reconciliación más que el castigo (Pensky, 2006, 137), la garantía del derecho a la verdad, dentro de un enfoque de reparación integral ha sufrido retrasos y ha adolecido de la suficiente atención por parte 
Aún quedan muchas preguntas, particularmente frente a su carácter extra judicial, y sobre todo frente a la forma como se complementará con los procesos judiciales donde se producirá verdad judicial. Algunos de los voceros y asesores de la iniciativa, han denominado "vasos comunicantes" a los medios que garantizarán la complementariedad que se espera entre la comisión y los procesos judiciales, o mejor entre la verdad histórica y la verdad judicial, sin embargo aún no es claro cual será la forma como se regulará esta complementariedad. La propuesta en este sentido tiene que ver, tal y cómo se estableció antes, en la posibilidad de potenciar, por un lado, los incentivos que, en el marco de la JEP se establezcan para contribuir a la verdad y, dado que pueden acogerse a esta jurisdicción, no sólo los excombatientes sino además todos aquellos que hayan estado involucrados en el conflicto no sólo como actores sino promotores y gestores de la violencia, que esta contribución permita un acceso a una verdad más amplia que garantice el verdadero establecimiento de las garantía de no repetición.

Tal y cómo ya se ha repetido en esta investigación, pensamos que Colombia le apunta al escenario propicio para establecer una verdadera política pública de verdad y memoria histórica, la cual, más allá de resultar transitoria, constituya un hito a nivel internacional frente a la forma como debemos afrontar un pasado con los niveles de violencia como los que hemos vivido en Colombia, los cuales además deben orientar y responder a la pregunta de ¿cómo pueden presentarse tamaños niveles de violencia, tal magnitud de violaciones a los derechos humanos, crímenes de lesa humanidad e infracciones a los derechos humanos en el marco de una democracia, que además por años se jactó de ser una de las más antiguas del continente?

Se espera que la comisión de la verdad, dado su carácter extrajudicial y su alto nivel, garantice la participación de sectores aún no involucrados en la construcción de la verdad. Esto requerirá nuevamente, de la voluntad política suficiente para permitir el acceso a archivos y develar información sobre los crímenes cometidos por actores estatales, militares y políticos así como permitir y facilitar acciones para que los grupos guerrilleros aporten sobre sus dinámicas de violencia y develen

de algunos sectores de la sociedad, sin embargo, esta noción de justicia, de la cuál la verdad es parte sustantiva se ha venido aplicando de manera fragmentada, pero progresiva. 
información que aún no entregan sobre el transcurrir de la guerra y sus protagonistas, todo lo cual debe conducir indefectiblemente a la construcción de una paz estable y duradera.

Para finalizar, es necesario decir que, en el contexto de implementación de justicia transicional en Colombia, no ha habido sistematicidad en la puesta en marcha de los mecanismos de acceso y restablecimiento de derechos de las víctimas, sino que las leyes han sido creadas como forma de subsanar los vacíos existentes en la implementación de las leyes marco de los procesos de desmovilización de grupos armados. Lo anterior evidencia un sistema basado en una idea de justicia retributiva en la que la verdad judicial sigue cobrando enorme protagonismo y la llamada centralidad de las víctimas es aun una idea vaga y reciente.

Lo anterior evidencia la necesidad de comenzar un trabajo encaminado a generar procesos de apropiación social de la verdad y la memoria que poco a poco se contruye, generar elementos pedagógicos que permitan un debate amplio sobre el relato que se comienza a elaborar, de lo contrario corremos el riesgo de atravesar experiencias ya vividas en otros países, particularmente los centro americanos, donde los relatos construidos a partir de las comisiones de la verdad, son parte de anaqueles, bibliotecas y material de investigadores y academicos, la construcción de verdad, si quiere aportar a un progreso moral de la sociedad, debe ser apropiada por los distintos sectores poblacionales, niños y niñas, jovenes, adultos mayores, indigenas, población LGBTI y afrocolombiana. 


\section{REFERENCIAS BIBLIOGRÁFICAS}

Alto Comisionado de las Naciones Unidas para los Derechos Humanos en Colombia (2012, 11 septiembre). La Justicia Transicional no es una forma 'blanda' de justicia". (11 de septiembre de 2012). Comunicado de Prensa Oficina. Recuperado de 01/08/2015 http://nacionesunidas.org.co/blog/2012/09/11/la-justicia-transicional-no-es-un-forma-blanda-dejusticia-nuevo-relator-especial-de-la-onu-pablo-de-greiff/

Arango Rivadeneira, Rodolfo. (2008). Derechos humanos como límite a la democracia: análisis de la ley de justicia y paz. Editorial Norma.

Centro Nacional de Memoria Histórica (2014). Yo aporto a la verdad. Acuerdos de contribución a la verdad y la memoria histórica. Informe $N^{\circ} 1$. Dirección de acuerdos de la verdad. Recuperado de 02/08/2015 http://www.oim.org.co/publicaciones-oim/reconciliacion-yreintegracion/3190-yo-aporto-a-la-verdad-acuerdos-de-contribucion-a-la-verdad-y-la-memoriahistorica.html

Comisión Colombiana de Juristas (2012). El Derecho a la Verdad y el Derecho Internacional. Recuperado de

01/08/2015

http://www.coljuristas.org/documentos/libros_e_informes/derecho_a_la_verdad_y_derecho_internaci onal.pdf

Comisión de Derechos Humanos de la ONU, (2005 8 Feb). Conjunto de principios actualizado para la protección y la promoción de los Derechos Humanos mediante la Lucha contra la Impunidad (E/CN.4/2005/102/Add.1. Recuperado. de: 02/08/2015 http://ap.ohchr.org/documents/dpag_s.aspx?si=E/cn.4/2005/102/Add.1

Comisión de Derechos Humanos de la ONU, (1993, 2 Jul). Estudio relativo al derecho de restitución, indemnización y rehabilitación a las víctimas de violaciones flagrantes de los derechos humanos y las libertades fundamentales. (E/CN.4/Sub.2/1993/8). Recuperado de http://www.corteidh.or.cr/tablas/10101.pdf 
Comisión de Derechos Humanos de la ONU (1985 21 jun). Estudio sobre las leyes de amnistía y el papel que desempeñan en la salvaguardia y la promoción de los derechos. Version original »Study on amnesty laws and their role in the safeguard and promotion of human rights Preliminary report by Mr. Louis Joinet, Special Rapporteur. (E/CN.4/Sub.2/1985/16)

Comisión de Derechos Humanos de la ONU (1997, 2 oct). Informe final revisado acerca de la cuestión de la impunidad de los autores de violaciones de los derechos humanos (derechos civiles y políticos) preparado por el Sr. Luis Joinet de conformidad con la Resolución 1996/119 de la Subcomisión, (E/CN.4/SUB.2/1997/20/Rev.1). Recuperado de https://documents-ddsny.un.org/doc/UNDOC/GEN/G97/129/15/PDF/G9712915.pdf?OpenElement

Comisión de Derechos Humanos de la ONU (1997). Proyecto de Principios y directrices básicos sobre el derecho de las víctimas de violaciones de las normas internacionales de derechos humanos y del Derecho Internacional Humanitario a interponer recursos y obtener reparaciones (ONU E/CN.4/1997/104)

Comisión de Derechos Humanos de la ONU $(1998,11$, feb) Informe del representante del Secretario General, Señor SR Francis M. Deng, presentado con arreglo a la resolución 1997/39 de la Comisión de Derechos Humanos. Adición principios rectores de los desplazamientos internos. (E/CN.4/1998/53/Add.2.) Recuperado de http://www.acnur.org/fileadmin/scripts/doc.php?file=fileadmin $\% 2$ FDocumentos $\% 2 F B D L \% 2 F 2001 \% 2 F$ $\underline{0022}$

Comisión de Derechos Humanos de la ONU (2000, 18, enero) Informe del relator especial sobre el derecho de restitución, indemnización y rehabilitación de las víctimas de graves violaciones de los derechos humanos y las libertades fundamentales (E/CN.4/2000/62) Recuperado de http://www.hchr.org.co/documentoseinformes/documentos/html/informes/onu/redrir/E-CN-4-2000$\underline{62 . h t m l}$

Comisión de Derechos Humanos de la ONU, (2005,28 Feb) Informe de la Alta Comisionada de las Naciones Unidas para los Derechos Humanos sobre la situación de los Derechos Humanos en Colombia. (E/CN.4/2005/10.) Recuperado de: 02/08/2015 http://daccess-ddsny.un.org/doc/UNDOC/GEN/G05/115/11/PDF/G0511511.pdf?OpenElement 
Comisión de Derechos de la ONU. (2004 27, feb) Promoción y Protección de los Derechos Humanos (E/CN.4/2004/88) CoRecuperado de: 02/08/2015 http://daccess-ddsny.un.org/doc/UNDOC/GEN/G04/113/58/PDF/G0411358.pdf?OpenElement

CIDH (2014). Derecho a la verdad en América (OEA/Ser.L/N/II.152 Doc 2). Recuperado de http://www.oas.org/es/cidh/informes/pdfs/Derecho-Verdad-es.pdf

CIDH (1986, 28 sept.). Informe Anual de la Comisión Interamericana de Derechos Humanos 1985-1986 (OEA/Ser.L/N/II.68, Doc.8 rev1) Recuperado de https://www.cidh.oas.org/annualrep/85.86span/Indice.htm

CIDH (2008). Lineamientos principales para una política integral de reparaciones, (OEA/Ser/L/V/ll.131Doc. 1). Recuperado de http://www.cidh.org/pdf\%20files/Lineamientos\%20principales\%20para\%20una\%20pol\%C3\%ADtica\% 20integral\%20de\%20reparaciones.pdf

CIDH (1999, 22 dic). Informe No. 136/99. Caso 10.488. Ignacio Ellacuría, S.J.; Segundo Montes, S.J.; Armando López, S.J.; Ignacio Martín Baró, S.J.; Joaquín López y López, S.J.; Juan Ramón Moreno, S.J.; Julia Elba Ramos; y Celina Mariceth Ramos. El Salvador. Recuperado de http://www.cidh.org/annualrep/99span/de\%20fondo/el\%20salvador10.488.htm

CIDH (2000, 13 abr.). Informe No. 37/00, Caso 11.481, Monseñor Oscar Arnulfo Romero y Galdámez, El Salvador. Recuperado de https://www.cidh.oas.org/annualrep/99span/De\%20Fondo/ElSalvador11481.htm

CIDH (2004, 13, dic.). Informe sobre el Proceso de Desmovilización en Colombia (OEA/Ser.L/V/II.120

Doc. 60). Recuperado de http://www.cidh.org/countryrep/colombia04sp/indice.htm

Comité Internacional de la Cruz Roja y la Media Luna Roja (1949). Convenio de Ginebra I para aliviar la suerte que corren los heridos y los enfermos de las fuerzas armadas en campaña.

Comité Internacional de la Cruz Roja y la Media Luna Roja (1949). Convenio de Ginebra III relativo al trato debido a los prisioneros de guerra.

Comité Internacional de la Cruz Roja y la Media Luna Roja (1949). Convenio de Ginebra IV relativo a la protección debida a las personas civiles en tiempo de guerra 
Comité Internacional de la Cruz Roja y la Media Luna Roja (1977). Protocolo I adicional a los Convenios de Ginebra de 1949 relativo a la protección de las víctimas de los conflictos armados internacionales.

Comité Internacional de la Cruz Roja y la Media Luna Roja (1977). Protocolo II adicional a los Convenios de Ginebra de 1949 relativo a la protección de las víctimas de los conflictos armados sin carácter internacional.

Convención Internacional para la protección de todas las personas contra las desapariciones forzadas 2005/23/sept. (ONU E/CN.4/2005/WG.22/WP.1/REV.4) Recuperado de http://www.gidh.org/files/Convencion\%20internacional\%20contra\%20desaparicion\%20forzada.pdf

Corte Constitucional. Sentencia C- 228 de 2002. Magistrados ponentes: Manuel José Cepeda Espinosa y Eduardo Montealegre Lynett

Corte Constitucional. Sentencia C- 370 de 2006. Magistrados ponentes: Manuel José Cepeda, Jaime Córdova Triviño, Rodrigo Escobar Gil, Marco Gerardo Monroy Cabra, Álvaro Tafur Galvis y Clara Inés Vargas Hernández.

Corte Constitucional. Sentencia T-576 de 2008. Magistrado ponente: Humberto Antonio Sierra Porto.

Corte Constitucional. Sentencia C-936 de 2010. Magistrado ponente Luís Ernesto Vargas Silva

Corte Constitucional. Sentencia C- 771 de 2011. Magistrado ponente: Nilson Pinilla Pinilla.

Corte Constitucional. Sentencia C- 715 de 2012. Magistrado ponente: Luis Ernesto Vargas Silva.

Corte IDH, caso Barrios Altos vs Perú. Sentencia de excepciones preliminares, fondo, reparaciones y costas. 14 de marzo de 2001.

Corte IDH, caso Diario Militar vs Guatemala. Sentencia de fondo, reparaciones y costas. 20 de noviembre de 2012.

Corte IDH, caso Gomes Lund y otros (Guerrilha do Araguaia) vs Brasil. Sentencia de excepciones preliminares, fondo, reparaciones y costas. 24 de noviembre de 2010. 
Corte IDH, caso Masacres de El Mozote y lugares aledaños vs El Salvador. Sentencia de fondo, reparaciones y costas. 25 de octubre de 2012.

Corte IDH, caso Zambrano Vélez y otros vs Ecuador. Sentencia, fondo, reparaciones y costas. 4 de julio de 2007.

Corte IDH (1987, 6 oct). Garantías Judiciales en Estados de Emergencia. Opinión Consultiva OC-9/87, Serie A No. 9.

Corte Suprema de Justicia (2006, 8 ago.). Proceso Nº 25797.

Corte Suprema de Justicia (2007, 11 jul.) Proceso N 26945. Magistrados Yesid Ramírez y Julio Enrique Socha.

Declaración Americana de Derechos del Hombre o Carta de Bogotá (1948)

Grupo de trabajo sobre las desapariciones forzadas 0 involuntarias, (2011, 26 de enero) Comentario General sobre el derecho a la verdad en relación con las desapariciones forzadas. $\begin{array}{llll}\text { (A/HRC/16/48). } & \text { Recuperado de } & \text { 02/08/2015 }\end{array}$ http://www.ohchr.org/Documents/lssues/Disappearances/GeneralCommentsDisappearances_sp.pdf

Gustavo Giraldo Gallon - Michael Reed Hurtado, Principios internacionales sobre impunidad y reparaciones. Compilación de documentos de la Organización de Naciones Unidas, 20 - 22, Comisión Colombiana de Juristas (CCJ Bogotá 2007)

Huhle, Reiner (2005). De Nuremberg a La Haya: Los crímenes de derechos humanos ante la justicia. Problemas, avances y perspectivas a los 60 años del Tribunal Militar Internacional de Nuremberg. Análisis Político (55) pp. 20-38

Naqvi, Y (2006, junio). El derecho a la verdad en el Derecho Internacional: ¿ ¿realidad o ficción?. Internacional Review of the Red Cross. (862). Recuperado de: 01/08/2015 https://www.icrc.org/spa/assets/files/other/irrc_862_naqvi.pdf

"ONU recuerda a Óscar Arnulfo Romero y aboga por el derecho a la verdad", Centro de Noticias ONU. 24 de marzo de 2016. Recuperado de http://www.un.org/spanish/News/story.asp?NewsID=34729\#.WAOwKWXaP-Z 
Orentlicher, D. (2004). ONU, Comisión de Derechos Humanos, 60 vo periodo de sesiones. Estudio independiente, con inclusión de recomendaciones, sobre las mejores prácticas para ayudar a los Estados a reforzar su capacidad nacional con miras a combatir todos los aspectos de la impunidad.Doc. E/CN.4/ 2004/88

Organización de los Estados Americanos, Convención Americana sobre Derechos Humanos (1969)

Pensky Max (2006), El pasado es otro pueblo. Un argumento a favor de los derechos póstumos como limitaciones normativas a las amnistías en De Gamboa Tapias, Camila (2006). Justicia transicional: teoría y praxis. Bogotá, Universidad del Rosario.

República de Colombia. Decreto 4436 de 2006. Por el cual se reglamenta la Ley 782 de 2002

República de Colombia. Decreto 3391 de 2006. Por la cual se reglamenta parcialmente la Ley 975 de 2005

República de Colombia. Decreto 2244 de 2011. Por el cual se adicionan funciones al Centro Nacional de Memoria Histórica

República de Colombia. Ley 418 de 1997 Por la cual se consagran instrumentos para la búsqueda de la convivencia, la eficacia de la justicia y se dictan otras disposiciones

República de Colombia. Ley 548 de 1999 Por medio de la cual se prorroga la vigencia de la Ley 418 del 26 de diciembre de 1997 y se dictan otras disposiciones

República de Colombia. Ley 600 de 2000 Por el cual se expide el código de procedimiento penal

República de Colombia. Ley 782 de 2002 Por medio de la cual se prorroga la vigencia de la Ley 418 de 1997, prorrogada y modificada por la Ley 548 de 1999 y se modifican algunas de sus disposiciones.

República de Colombia. Ley 906 de 2004 Por la cual se expide el código de procedimiento penal 
República de Colombia. Ley 975 de 2005. "Ley de Justicia y Paz" Por la cual se dictan disposiciones para la reincorporación de miembros de grupos armados organizados al margen de la ley, que contribuyan de manera efectiva a la consecución de la paz nacional y se dictan otras disposiciones para acuerdos humanitarios.

República de Colombia. Ley 1106 de 2006 Por medio de la cual se prorroga la vigencia de la Ley 418 de 1997, prorrogada y modificada por las Leyes 548 de 1999 y 782 del 2002 y se modifican algunas de sus disposiciones.

República de Colombia. Ley 1312 de 2009 Por medio de la cual se reforma la Ley 906 en lo relacionado con el principio de oportunidad

República de Colombia. Ley 1424 de 2010 Por la cual se dictan disposiciones de justicia transicional que garanticen verdad, justicia y reparación a las víctimas de desmovilizados de grupos organizados al margen de la ley, se conceden beneficios jurídicos y se dictan otras disposiciones.

República de Colombia. Ley 1421 de 2010 Por medio de la cual se prorroga la Ley 418 de 1997, prorrogada y modificada por las Leyes $\underline{548}$ de 1999, $\underline{782}$ de 2002 y 1106 de 2006.

República de Colombia. Ley 1448 de 2011. "Ley de víctimas y Restitución de Tierras" Por la cual se dictan medidas de atención, asistencia y reparación integral a las víctimas del conflicto armado interno y se dictan otras disposiciones.

República de Colombia. Ley 1592 de 2012 Por medio de la cual se introducen modificaciones a la ley 975 de 2005 "por la cual se dictan disposiciones para la reincorporación de miembros de grupos armados organizados al margen de la ley, que contribuyan de manera efectiva a consecución de la paz nacional y se dictan otras disposiciones para acuerdos humanitarios" y se dictan otras disposiciones".

Resolución N 47/133 de la Asamblea General de la ONU (18 de diciembre de 1992) Declaración sobre la protección de todas las personas contra las desapariciones forzadas. Recuperado de http://www.hchr.org.co/documentoseinformes/documentos/html/pactos/declaracion_sobre_proteccion _personas.html 
Resolución Nº 1989/65 (24 de mayo de 1989). Recomendaciones por el Consejo Económico y Social de las Naciones Unidas.

Resolución N 55/89 (4 de diciembre de 2000) de la Asamblea General de la ONU.

Resolución N ${ }^{\circ}$ 60/147 de la Asamblea General de la ONU. (16 de diciembre de 2005). Principios y directrices básicos sobre el derecho de las víctimas de violaciones manifiestas de las normas internacionales de Derechos Humanos y de violaciones graves del Derecho Internacional Humanitario a interponer recursos y obtener reparaciones. Recuperado de: http://www.2.ohchr.org/spanish/law/reparaciones.htm.

Resolución AG/RES 2175(XXXVI-O/06) de la Organización de los Estados Americanos. El Derecho a la verdad. Recuperado de http://www.acnur.org/t3/fileadmin/Documentos/BDL/2013/9034.pdf?view=1

Unión Europea (2000). Carta de los Derechos Fundamentales de la Unión Europea (2000/C364/01), en diario oficial de las comunidades europeas, C 364/1 de 18 de diciembre de 2000. Recuperado de http://www.europarl.europa.eu/charter/pdf/text_es.pdf

Santos, Boaventura de Souza (2014). Derechos Humanos, Democracia y Desarrollo. Bogotá: colección Dejusticia.

Secretary - General urges respect for cease - fire as Colombia peace talks open", Comunicado de prensa SG/SM/9400 del 01 de julio de 2004 (Original en Inglés). Recuperado de http://www.un.org/press/en/2004/sgsm9400.doc.htm

Uprimy Rodrigo, Saffon Maria Paula (2006), Derecho a la verdad: alcances y límites de la verdad judicial en De Gamboa Tapias, Camila (2006). Justicia transicional: teoría y praxis. Bogotá, Universidad del Rosario.

Vivian Newman - Pont, Falso o Verdadero ( $i$ El derecho a la verdad es norma imperativa internacional?), 14, International Law, Revista Colombiana de Derecho Internacional, 43 - 69, (2009.) 
